VICENTE DE PAULO FERREIRA MARQUES SOBRINHO

\title{
ADIÇÃO DE POEIRA DE ACIARIA ELÉTRICA EM FERRO GUSA LÍQUIDO
}

São Paulo

2012 
VICENTE DE PAULO FERREIRA MARQUES SOBRINHO

\section{ADIÇÃO DE POEIRA DE ACIARIA \\ ELÉTRICA EM FERRO GUSA LÍQUIDO}

Tese apresentada à Escola Politécnica da Universidade de São Paulo como parte dos requisitos para obtenção do título de Doutor em Engenharia.

São Paulo 
Tese apresentada à Escola Politécnica da Universidade de São Paulo como parte dos requisitos para obtenção do título de Doutor em Engenharia.

Área de Concentração: Engenharia Metalúrgica e de Materiais.

Orientador: Profa. Dra. Denise Crocce Romano Espinosa

São Paulo 
Este exemplar foi revisado e alterado em relação à versão original, sob responsabilidade única do autor e com a anuência de seu orientador.

São Paulo, 11 de outubro de 2012.

Assinatura do autor

Assinatura do orientador

FICHA CATALOGRÁFICA

Marques Sobrinho, Vicente de Paulo Ferreira Adição de poeira de aciaria elétrica em ferro gusa líquido / V.P.F. Marques Sobrinho. -- ed.rev. -- São Paulo, 2012. $106 \mathrm{p}$.

Tese (Doutorado) - Escola Politécnica da Universidade de São Paulo. Departamento de Engenharia Metalúrgica e de Materiais.

1. Resíduos siderúrgicos 2. Reciclagem 3. Poeira 4. Ferro gusa I. Universidade de São Paulo. Escola Politécnica. Departamento de Engenharia Metalúrgica e de Materiais II. t. 


\section{RESUMO}

Esta pesquisa tem como objetivo estudar o processo de incorporação de massa ao ferro gusa final e a volatilização da massa da poeira de aciaria elétrica (PAE) mediante adição em ferro gusa líquido à temperatura de 1400, 1450 e $1500^{\circ} \mathrm{C}$, alterando-se o percentual de PAE a ser adicionado e o teor de silício do ferro gusa. Previamente, a PAE foi caracterizada utilizando-se as seguintes técnicas: análise química, análise granulométrica, área de superfície específica, difração de raios-X, microscopia eletrônica de varredura (MEV) e análise de micro-regiões por espectroscopia de energia dispersiva (EDS). Após a caracterização, a PAE a ser adicionada ao banho de gusa líquido, foi aglomerada sob a forma de briquetes. A realização dos experimentos de fusão, em escala de laboratório, ocorreu em um forno de resistências com controlador de temperatura. Os experimentos de fusão utilizaram cadinhos de alumina. Um fluxo de gás inerte (argônio) foi mantido no interior do forno durante a realização dos experimentos. O resultado da amostra da PAE volatilizada mostra que há aumento na concentração de zinco quando se compara com a concentração de zinco da PAE na forma "como recebido". Os valores das energias de ativação aparente estão na faixa de 75 a $177 \mathrm{~kJ} / \mathrm{mol}$ para experimentos realizados com ferro gusa com teor de silício variando de 1,38 a $1,85 \%$ e entre 245 e $504 \mathrm{~kJ} / \mathrm{mol}$ para experimentos realizados com ferro gusa com teor de silício variando entre 0,23 e $0,36 \%$.

Palavras-chave: Resíduos siderúrgicos. Poeiras. Reciclagem. Ferro gusa. 


\begin{abstract}
This research aims to study the process of incorporation of mass in final hot metal and the mass volatilization of electric arc furnace dust (EAFD) by addition in hot metal at a temperature of 1,$400 ; 1,450$ and 1,500 degrees Celsius, altering experimental conditions, such as the percentage of EAFD to be added and the percentage of silicon in hot metal. Previously, the EAFD was characterized using the following techniques: chemical analysis, size analysis, X-ray diffraction, scanning electron microscopy (SEM) and energy dispersive spectroscopy (EDS) microanalysis. After characterization, the EAFD to be added to the hot metal was agglomerated in the form of briquettes. The fusion experiments in laboratory scale took place in a vertical tubular furnace with temperature control. It was used alumina crucibles in the fusion experiments. A flow of inert gas (argon) was maintained inside the furnace during the experiments. The result of the EAFD volatilized sample shows that there is an increase in the zinc concentration when compared with the concentration of zinc presented in EAFD "as received". The values of the apparent activation energies are in the range $75-177 \mathrm{~kJ} / \mathrm{mol}$ for experiments with hot metal with the silicon content ranging from 1.38 to $1.85 \%$ and between $245-504 \mathrm{~kJ} / \mathrm{mol}$ to experiments performed with hot metal with silicon content ranging from 0.23 to $0.36 \%$.
\end{abstract}

Key-words: Siderurgical residue. Dust. Recycling. Hot metal. 


\section{AGRADECIMENTOS}

A Deus por ter permitido a realização deste trabalho.

Aos professores Denise Crocce Romano Espinosa e Jorge Alberto Soares Tenório, pela orientação, dedicação, estímulo e empenho no transcurso deste trabalho.

Aos colegas, professores e funcionários da USP.

Aos colegas, professores e funcionários do IFES.

Aos meus familiares.

Agradeço a todos aqueles que direta ou indiretamente contribuíram para a concretização deste trabalho. 


\section{ÍNDICE DE FIGURAS}

Figura 1. Fluxo de produção de aço via conversor e via forno elétrico de aciaria.....13

Figura 2. Emissão de poeira durante o processamento do aço. .............................15

Figura 3. Pluma de gases durante o carregamento do forno. .................................16

Figura 4. Vista panorâmica da aciaria elétrica....................................................17

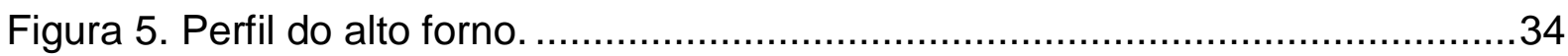

Figura 6. Principais desenvolvimentos em aciaria elétrica. .......................................39

Figura 7. Energia livre padrão de Gibbs para as reações de redução. .....................44

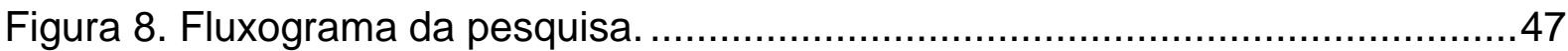

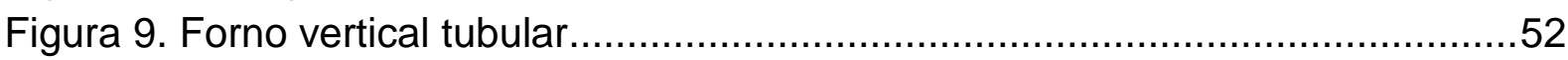

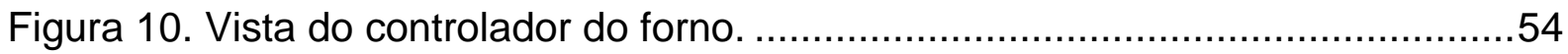

Figura 11. Vista superior da câmara interna com resistência....................................54

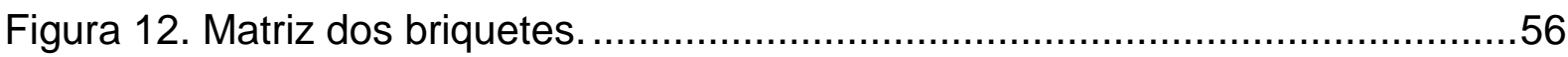

Figura 13. Distribuição do tamanho das partículas da PAE na forma "como recebido".

Figura 14. Espectro de difração de raios-X da amostra da PAE e a identificação dos picos.

Figura 15. (A) Imagem de elétrons retro-espalhados das partículas de PAE, (B) Imagem de elétrons secundários da região 2 com maior aumento...........................63

Figura 16. Espectro de EDS correspondente à região 1 (região da esfera)..............64

Figura 17. Espectro de EDS da região 2 (região clara)..........................................64

Figura 18. Variação do teor de silício (Esteq A Si) em função do tempo. ..................66

Figura 19. Variação do teor de silício (Esteq M Si) em função do tempo...................66

Figura 20. Simulação do teor de silício de equilíbrio no ferro líquido. .......................67

Figura 21. Energia livre das reações de redução do $\mathrm{FeO}$.......................................69

Figura 22. Comportamento do carbono do ferro gusa...........................................73

Figura 23. Variação da porcentagem de Si em relação ao tempo na temperatura

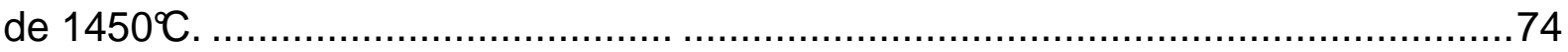

Figura 24. Variação da porcentagem de Si em relação ao tempo na temperatura

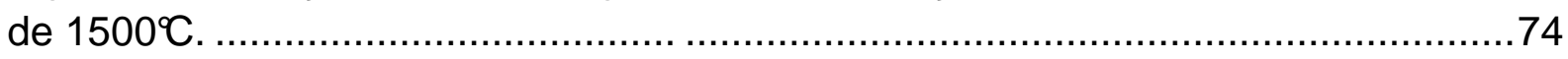

Figura 25. Distribuição granulométrica da poeira resultante do processo.................76

Figura 26. Composição mineralógica da poeira resultante do processo por DRX ...77

Figura 27. Imagem de partículas de poeira resultante do processo obtida em MEV

Figura 28. Espectro de EDS da região da lamela da poeira produzida pelo

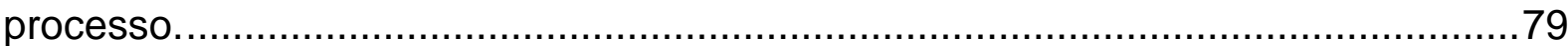

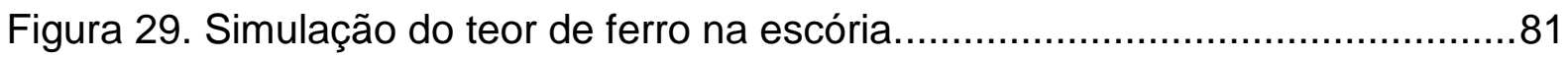

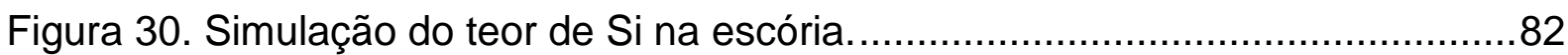

Figura 31. Perfil térmico da escória A Si com poeira estequiométrica. ....................83

Figura 32. Perfil térmico da escória $B$ Si com poeira estequiométrica. .....................84

Figura 33. Comportamento dos óxidos na escória (1400 esteq Asi) em equilíbrio metal escória. 
Figura 34. Espectro de EDS da escória final (1400 Esteq A Si).

.86

Figura 35. Difração de raios- $X$ da escória final do experimento (1400 Esteq Asi).....86

Figura 36. Variação do teor de silício no gusa líquido [1400 Esteq A Si] .................87

Figura 37. Variação do $\ln [($ CSi-CSieq) /(CSio-CSieq)] ........................................ 88

Figura 38. Curva de Arrhenius para a classe de experimentos Esteq B Si..............90 


\section{ÍNDICE DE TABELAS}

Tabela 1. Intervalo de composição química para alguns elementos presentes em

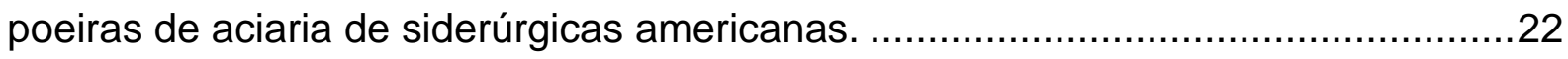

Tabela 2. Caracterização dos ensaios realizados...............................................55

Tabela 3. Composição química elementar da PAE na forma "como recebido" por

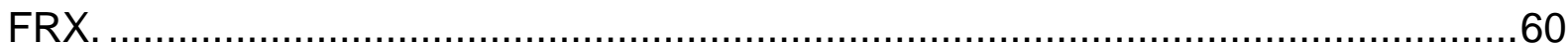

Tabela 4. Variação da porcentagem de silício do banho em função do tempo. ........65

Tabela 5. Atividade do $\mathrm{SiO}_{2}$ e $\mathrm{FeO}$ nas escórias finais........................................70

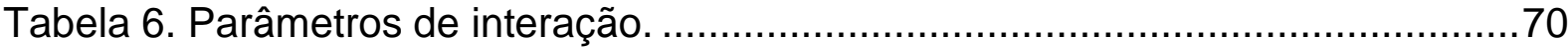

Tabela 7. Variação da energia Livre de Gibbs das reações de redução do $\mathrm{FeO}$

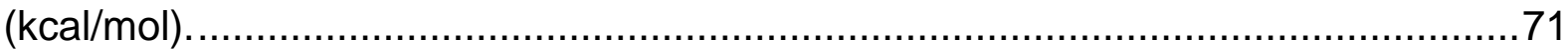

Tabela 8. Variação da energia Livre de Gibbs das reações de redução do $\mathrm{SiO}_{2}$

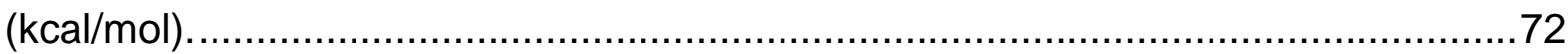

Tabela 9. Composição química elementar da poeira resultante do processo por FRX.

Tabela 10. Composição química de escória final por EDS ……..............................8

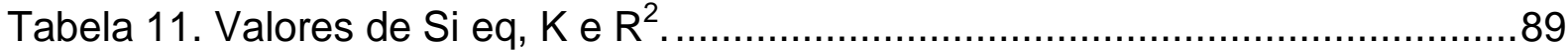

Tabela 12. Valores de energia de ativação aparente............................................90 


\section{SUMÁRIO}

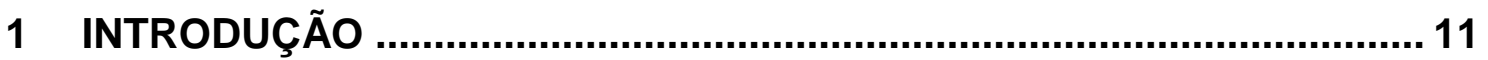

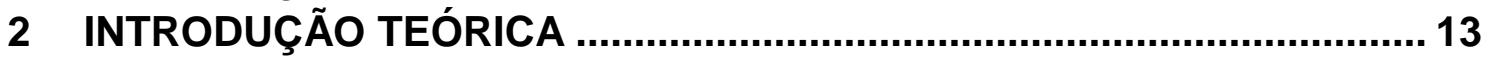

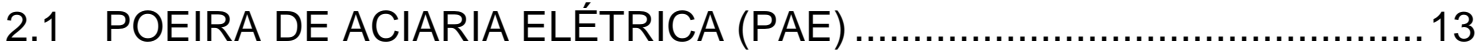

2.1.1 Mecanismos de formação das poeiras de aciaria...................................17

2.1.2 Propriedades físicas da poeira de aciaria elétrica..................................20

2.1.3 Composição química e mineralógica da poeira de aciaria elétrica ..........21

2.1.4 Processo para tratamento de poeiras de aciaria elétrica .........................23

2.2 NORMALIZAÇÃO BRASILEIRA SOBRE RESÍDUOS ............................26

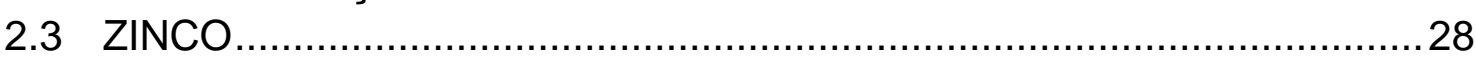

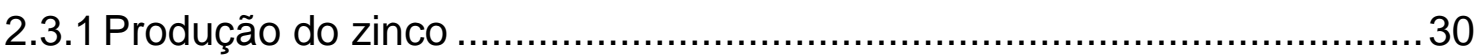

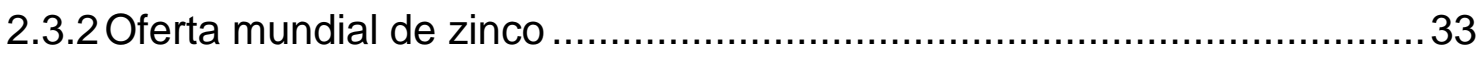

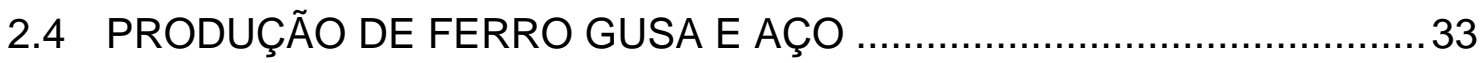

2.4.1 Produção de ferro gusa em alto forno....................................................33

2.4.2 Produção de aço em forno elétrico a arco .......................................... 37

2.5 TERMODINÂMICA DA REDUÇÃO DOS ÓXIDOS DE FERRO E ZINCO

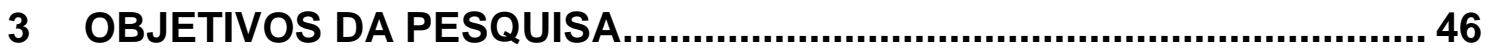

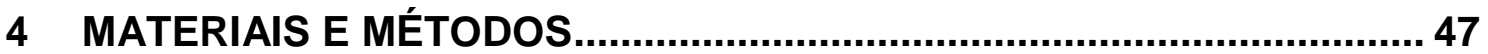

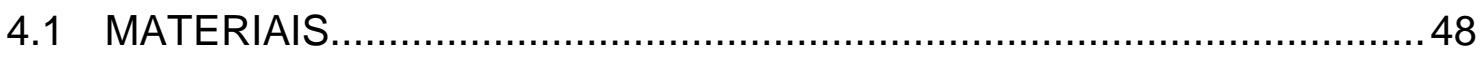

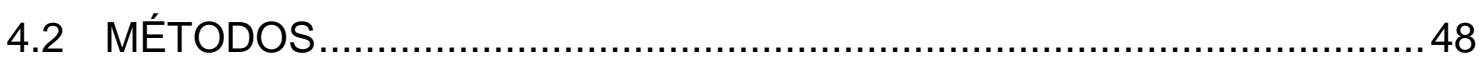

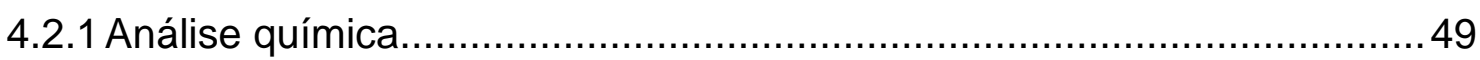

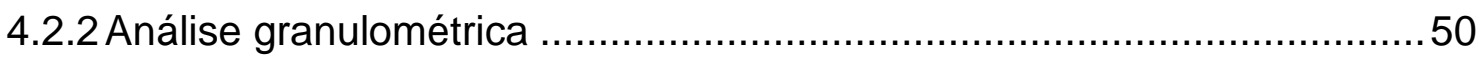

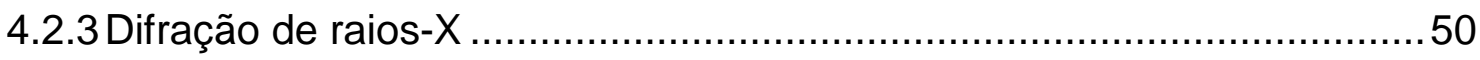

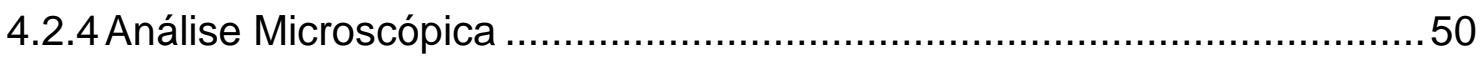

4.3 METODOLOGIA ADOTADA PARA ADIÇÃO DE PAE EM GUSA

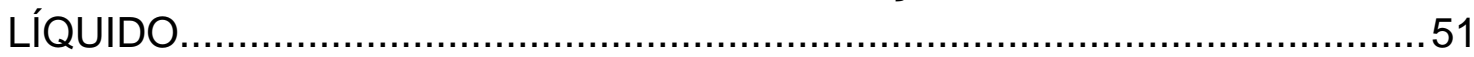

4.3.1 Descrição do forno elétrico de resistências .............................................53

4.3.2 Cálculo de massa dos experimentos e briquetagem da mistura...............54

4.3.3 Captação de emissões e material volátil...............................................56

4.4 ANÁLISE CINÉTICA DA REDUÇÃO DO ÓXIDO DE FERRO .................57

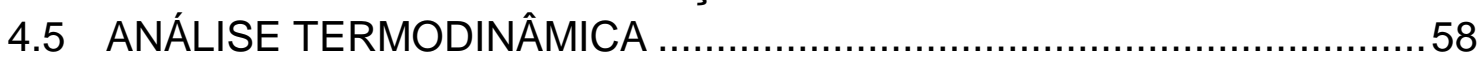

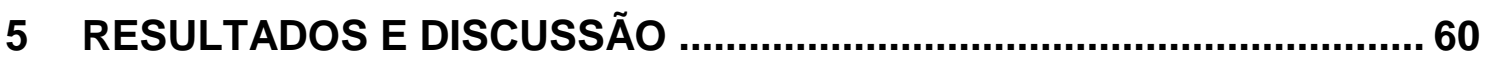

5.1 CARACTERIZAÇÃO DA POEIRA DE ACIARIA ELÉTRICA....................60

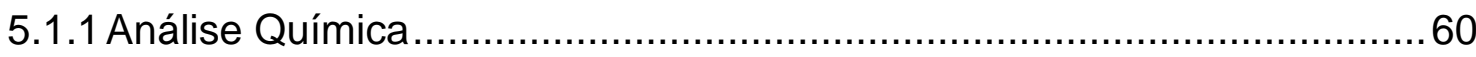

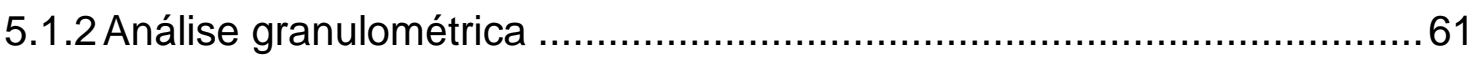

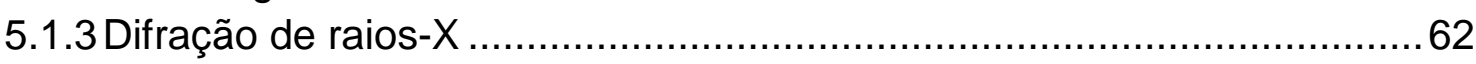

5.1.4 Microscopia eletrônica de varredura e análise de micro-regiões por

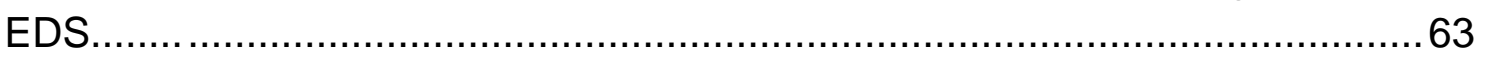

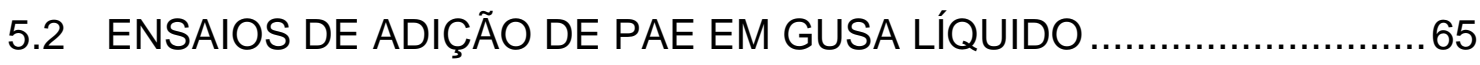

5.2.1 Análise da influência da massa de PAE ...............................................74

5.3 CARACTERIZAÇÃO DA POEIRA RESULTANTE DO PROCESSO ........75 


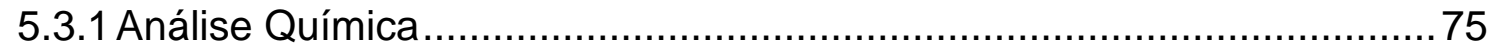

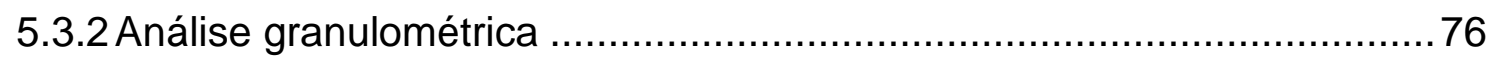

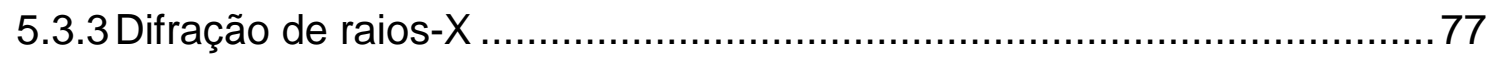

5.3.4 Microscopia Eletrônica de Varredura e Análise de Micro-Regiões por EDS. .78 5.4 CARACTERIZAÇÃO DAS ESCÓRIAS RESULTANTES

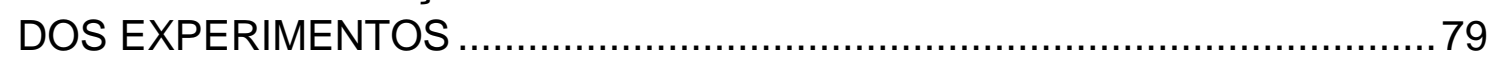

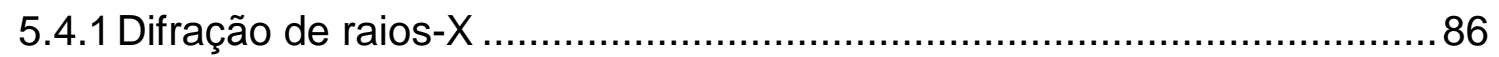

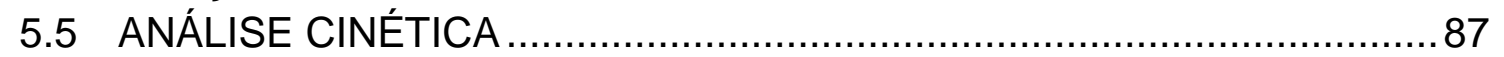

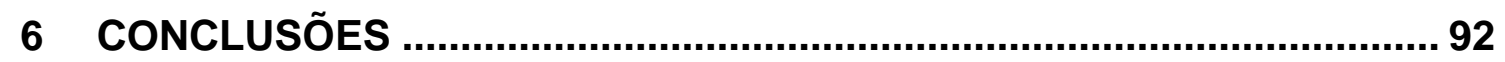

7 SUGESTÕES PARA TRABALHOS FUTUROS...................................... 94

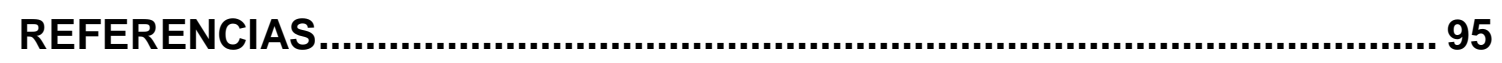

ANEXO A 


\section{INTRODUÇÃO}

A poeira de aciaria elétrica (PAE), gerada no forno elétrico a arco, representa um dos maiores problemas pelo seu conteúdo em elementos químicos, tais como zinco, ferro, chumbo, cromo, cádmio, entre outros, emitidos à atmosfera durante a fabricação do aço ${ }^{[1]}$.

A PAE é classificada como resíduo perigoso no Brasil de acordo com os critérios descritos na NBR $10.004: 2004^{[2]}$, bem como em outros países produtores de aço, como Estados Unidos da América ${ }^{[3,4]}$, Japão ${ }^{[5]}$ e nos países que integram a União Européia ${ }^{[6]}$. Devido a esta classificação, o manuseio da PAE no Brasil exige cuidados especiais.

Exigências impostas pela legislação ambiental somada com a necessidade de minimização de custos fazem com que as empresas metalúrgicas e siderúrgicas busquem tecnologias para solucionar os problemas da geração de resíduos ${ }^{[7]}$.

A produção brasileira de aço bruto $^{[8]}$, após a crise mundial de 2008, cresceu 23,8\% em 2010 comparando com o ano de 2009 (de $26,506 \times 10^{6}$ t em 2009 para $32,819 \times 10^{6}$ ton em 2010 ), $7,13 \%$ em 2011 comparando com o ano de 2010 (de $32,819 \times 10^{6}$ t em 2009 para 35,162 $\times 10^{6}$ ton em 2011) e tomando como base o mês de abril de $2012^{[9]}$, a produção dos últimos 12 meses foi de $35,419 \times 10^{6} \mathrm{t}$ mostrando que a produção está em crescimento, consequentemente cresce também a geração de PAE.

Considerando ainda que o aumento da garantia contra a corrosão dos veículos tem forçado as montadoras a substituir as chapas laminadas a frio e galvanizadas pelo processo eletrolítico por chapas galvanizadas pelo processo 
de galvanização a quente. Esta substituição tem como conseqüência o aumento da quantidade de zinco na sucata que alimenta o forno elétrico, o que contribui para uma maior concentração do zinco na poeira de aciaria elétrica ${ }^{[10]}$.

No Brasil, ainda não existe um processo industrial, em operação, que utilize exclusivamente esta PAE ou que faça o tratamento da mesma para uma deposição.

Esta pesquisa tem como objetivo estudar em escala laboratorial a incorporação de massa no ferro gusa final e a volatilização da massa da poeira de aciaria elétrica mediante adição em ferro gusa líquido variando-se a temperatura do banho de ferro gusa, a massa de PAE adicionada e 0 percentual de silício do ferro gusa. Este estudo tem também como objetivo realizar uma análise cinética da redução do óxido de ferro pelo silício. 


\section{INTRODUÇÃO TEÓRICA}

\subsection{POEIRA DE ACIARIA ELÉTRICA (PAE)}

A produção de aço pode ser feita a partir de várias rotas de processo. As duas mais utilizadas são as aciarias elétricas como e os conversores a oxigênio $^{[1,7]}$. A Figura 1 apresenta o fluxograma de produção, mostrando as seqüências para produção de aço via conversor e via forno elétrico de aciaria.

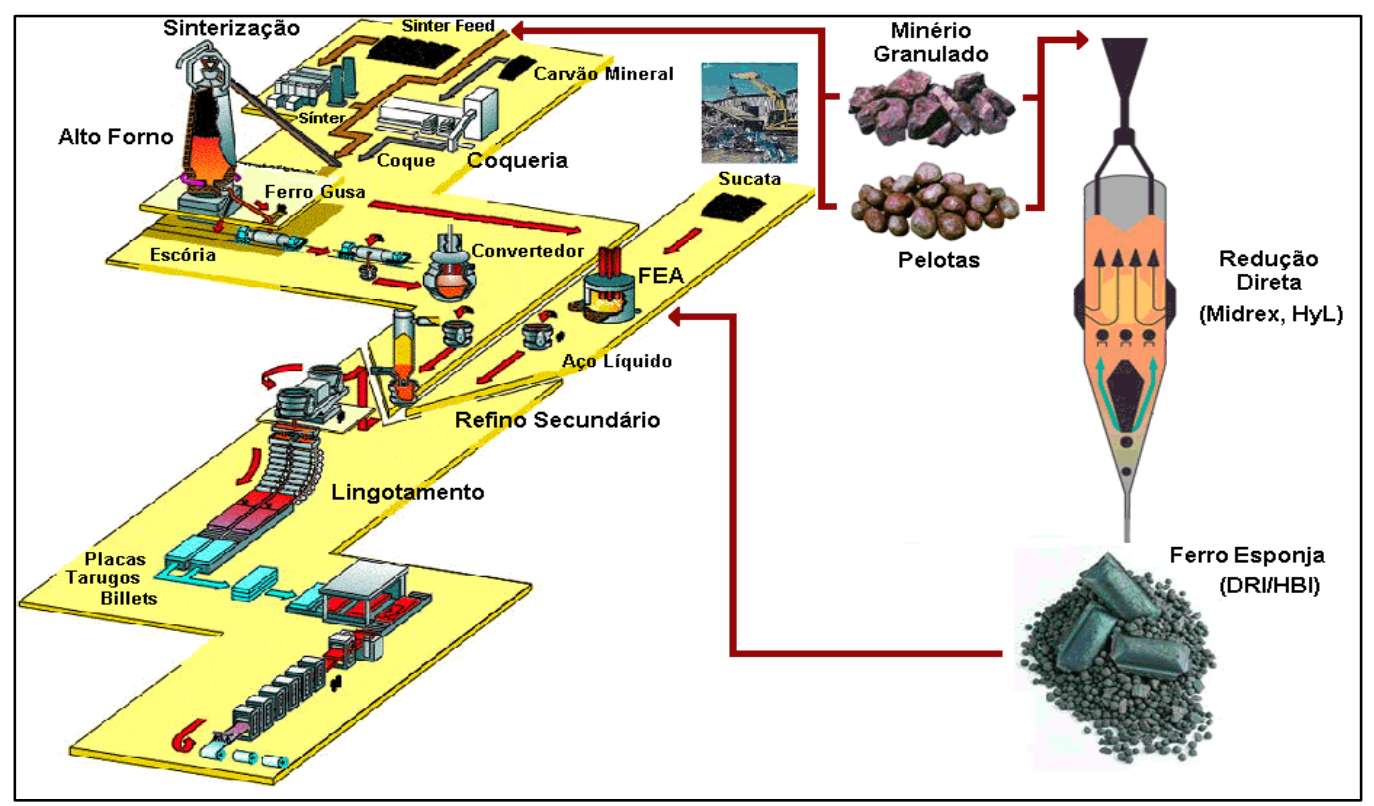

Figura 1. Fluxo de produção de aço via conversor e via forno elétrico de aciaria ${ }^{[11]}$.

Independente do tipo de forno ou do processo utilizado, fabricar aço é uma operação que impacta o meio ambiente em função de emissão de uma grande quantidade de poeira $^{[1]}$. Vários autores ${ }^{[12,13,14,15,16,17]}$ têm relatado os índices da quantidade gerada de poeira de aciaria com relação à produção de aço, tais valores mostram que entre 15 a $20 \mathrm{~kg}$ de PAE são gerados para cada tonelada de aço que é produzida. 
No mundo, a quantidade de aço produzida via forno elétrico a arco vem aumentando a cada ano, conseqüentemente, a quantidade de PAE também está aumentando ${ }^{[18]}$. A PAE é classificada, de acordo com norma NBR 10004:2004, como resíduo sólido perigoso, Classe $\mathrm{I}^{[2]}$.

No estado do Rio Grande do Sul, a FEPAM, órgão ambiental estadual, exige que este tipo de resíduo seja estocado em locais adequados, ou seja, locais cobertos e protegidos das intempéries ${ }^{[1]}$.

No estado de São Paulo, a CETESB, órgão ambiental estadual, exige que a PAE passe por testes de solubilização e lixiviação para se tenha um conhecimento do grau de toxicidade deste material, além disso, ocorrendo o descarte em aterros, estes aterros deverão ser monitorados periodicamente para seja evitada uma possível contaminação dos lençóis freáticos ${ }^{[7]}$.

No processo de fabricação via forno elétrico a arco, a sucata de aço é fundida via ação do arco voltaico, energia proveniente de queimadores e reações químicas, principalmente as resultantes da injeção de oxigênio. Vários materiais são adicionados ao processo, tais como cal, grafite, fluorita e elementos de liga ${ }^{[19]}$. A emissão de PAE durante o processamento de aço em forno elétrico pode ser exemplificada através da observação da Figura 2.

A poeira de aciaria é formada pela volatilização de metais da carga, tais como zinco, cádmio e chumbo, que devido à temperatura de trabalho nos fornos elétricos passam para o estado gasoso (as temperaturas atingem até $1680^{\circ} \mathrm{C}$ ), são oxidados pelo excesso de oxigênio e posteriormente são condensados devido ao resfriamento provocado pela injeção de ar vindo do sistema de resfriamento ${ }^{[1]}$. 
A emissão de poeiras durante o processamento de aço em forno elétrico pode ser exemplificada através da observação da Figura 2.

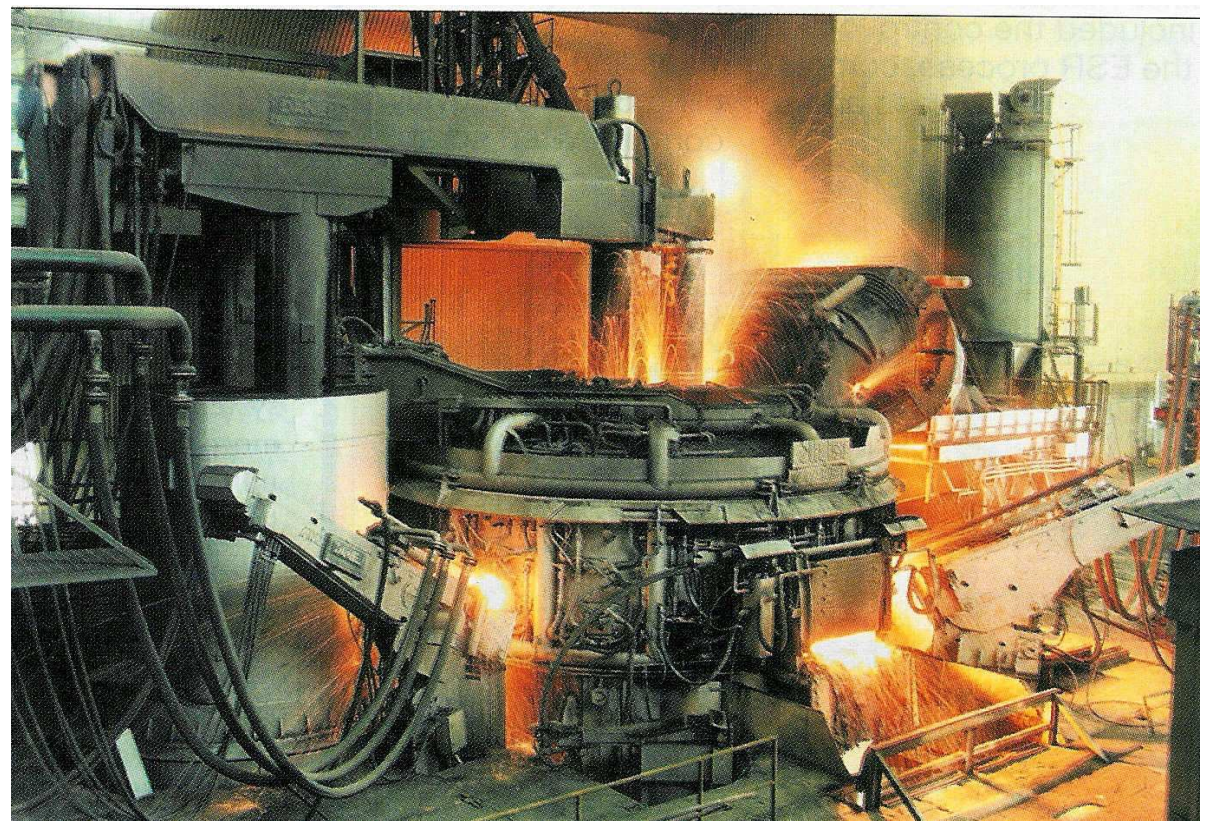

Figura 2. Emissão de poeira durante o processamento do aço.

As partículas condensadas e outros materiais particulados são então coletados em equipamentos de controle de poluição atmosférica ${ }^{[7]}$.

As emissões de PAE estão associadas a todas as fases de operação do forno. A pluma de gases que sai do forno quando a sucata está sendo carregada é apresentada na Figura 3. Esta pluma se forma devido à ignição de materiais combustíveis agregados à sucata metálica, gerada quando em contato com o aço já fundido na base do forno ${ }^{[1]}$. 


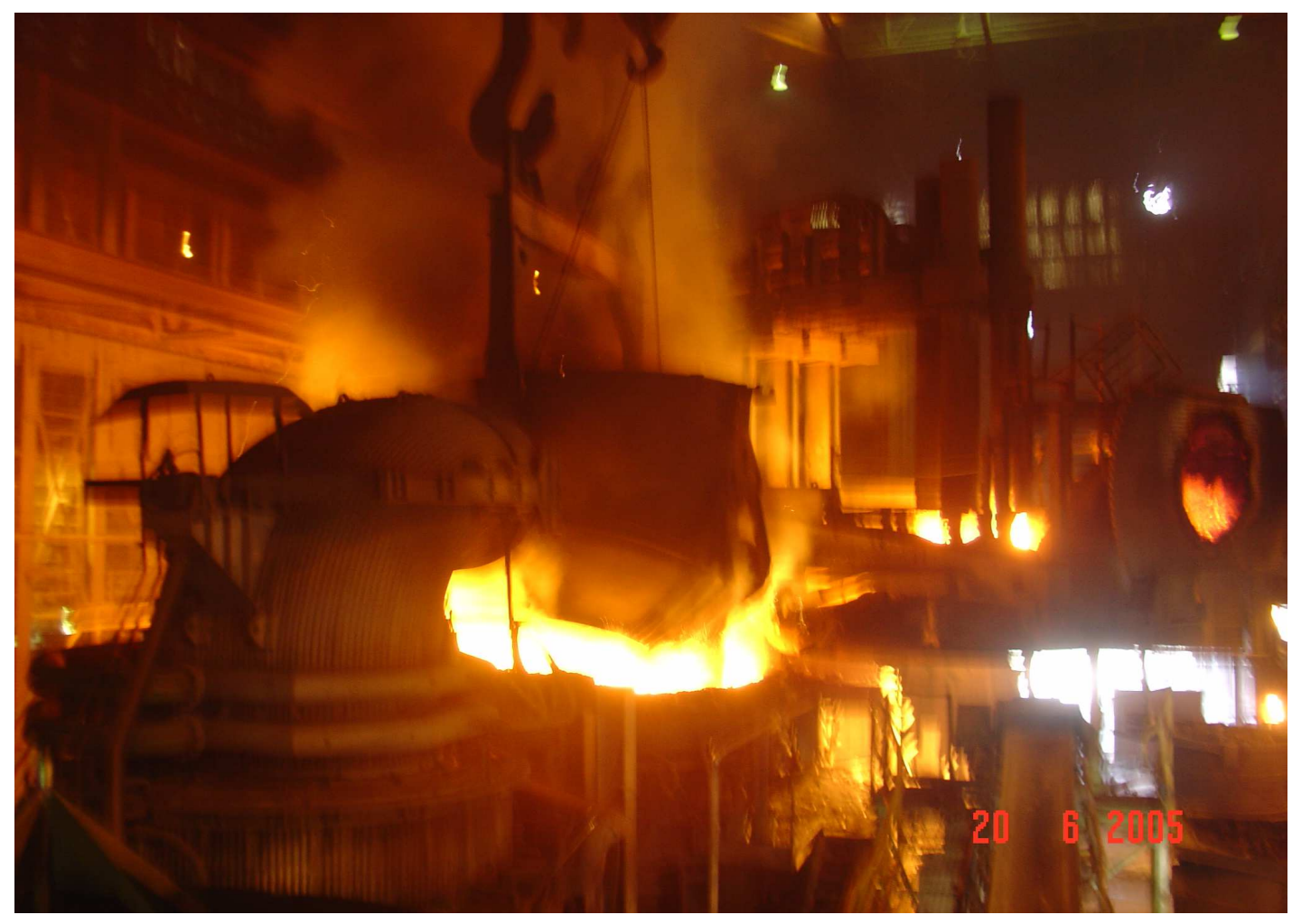

Figura 3. Pluma de gases durante o carregamento do forno.

Para impedir a poluição do ar, unidades de despoeiramento tais como instalações para lavagem de gases, ciclones, filtros de mangas e precipitadores eletrostáticos são instalados para compor um sistema de limpeza de gases ${ }^{[20]}$.

A importância dada à limpeza dos gases em uma usina siderúrgica pode diferir, mas é oportuno ressaltar que isto não é somente mais um assunto para o empreendedor da usina decidir, atualmente, órgãos governamentais, órgãos não-governamentais e a própria comunidade através de audiências públicas têm participação na tomada de decisão ${ }^{[21]}$.

A Figura 4 mostra uma vista panorâmica de uma aciaria elétrica fora do Brasil, onde se vê o impacto visual da PAE quando se opera sem o equipamento de controle da poluição do ar. Nesta data (21 de janeiro de 2008) o equipamento estava em manutenção programada. 


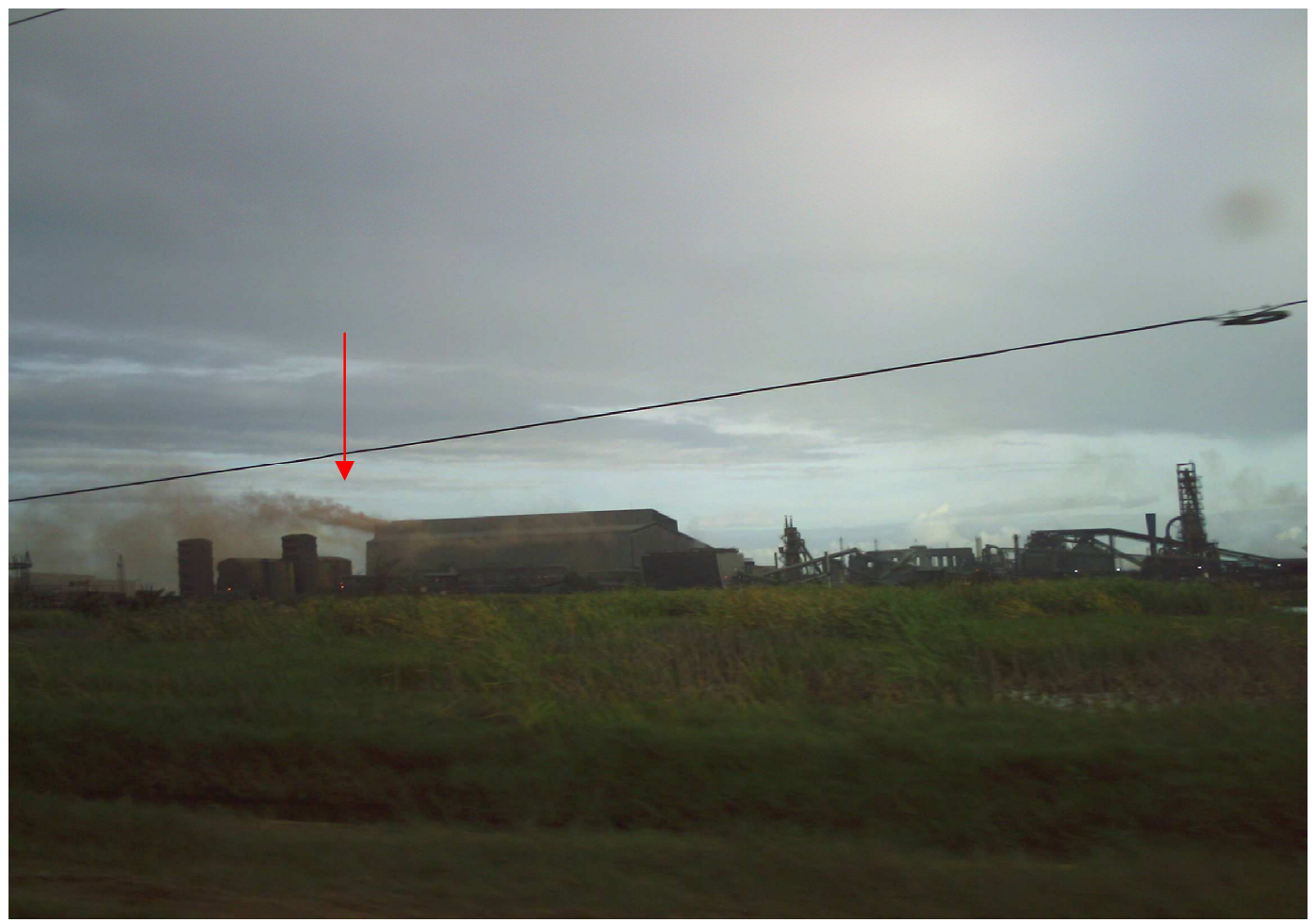

Figura 4. Vista panorâmica da aciaria elétrica.

\subsubsection{Mecanismos de formação das poeiras de aciaria}

O conhecimento do mecanismo de formação das poeiras de aciaria pode contribuir para uma prática operacional na fabricação do aço para a diminuição da sua formação ${ }^{[7]}$.

Turkdogan, Leake, Grieveson e Darken ${ }^{[22,23]}$, estudaram o possível mecanismo de formação de pós gerados em aciarias a oxigênio. Segundo os referidos autores, a taxa de geração de poeira durante a operação em conversores é fruto da temperatura situada na zona de impacto da lança de oxigênio, período em que ocorre uma maior formação de poeira de aciaria.

Morris, Riott e lilig ${ }^{[24]}$ relatam que a formação de poeiras em conversores é devida principalmente à ejeção de partículas de metal líquido, ocasionada pela reação de oxigênio com monóxido de carbono na superfície do banho metálico. 
Baker ${ }^{[17]}$, usando uma câmara projetada para fazer com que gotas de Fe-C percorressem uma região rica em oxigênio, verificou que as gotas desintegravam-se, produzindo gotas ainda menores.

Ellis e Glover ${ }^{[25]}$, tiveram como objetivo descrever quantitativamente as proporções de pós produzidos por vaporização ou pela ação das bolhas de monóxido de carbono. Com o intuito de avaliar o grau de participação destes mecanismos, foram injetadas em direção às ligas $\mathrm{Fe}-\mathrm{C}\left(1600^{\circ} \mathrm{C}\right)$ várias misturas de oxigênio e argônio. Segundo os referidos autores, a ação das bolhas de monóxido de carbono e a posterior oxidação e explosão das gotículas ejetadas contribuem bastante para a formação do pó tanto em escala laboratorial, pois $96 \%$ do pó foram gerados pela ação das bolhas, como em escala industrial. Afirmam ainda que a explosão das gotas inicialmente ejetadas ocorre porque uma porção da camada de óxido que cobre a gota é sugada para dentro da mesma, fazendo com que haja a formação de monóxido de carbono e a conseqüente explosão da gota.

See e Warner ${ }^{[26]}$ e Roddis ${ }^{[27]}$, pelo estudo da remoção de carbono de gotas de Fe-C passando por uma atmosfera oxidante, também concluíram que a formação da poeira é devida principalmente a dois mecanismos: ejeção de partículas de Fe-C promovida pela ação das bolhas de monóxido de carbono e que as partículas então formadas explodem e geram partículas ainda menores.

Li e Tsai ${ }^{[3]}$, estudando o mecanismo de formação de poeiras geradas em fornos elétricos a arco, mais especificamente partículas de espinélio de ferro ricas em zinco, propuseram uma teoria para a formação das grandes partículas desse tipo. De acordo com os autores acima citados, quando a sucata de aço é fundida em forno elétrico a arco, o zinco é facilmente vaporizado (evapora a 
$907^{\circ} \mathrm{C}, 1 \mathrm{~atm}$ ) devido a sua alta pressão de vapor. Embora, uma parte do zinco passa para a escória na forma de zincita $(\mathrm{ZnO})$. Em temperaturas altas, quando em contato tanto com hematita $\left(\mathrm{Fe}_{2} \mathrm{O}_{3}\right)$ ou magnetita $\left(\mathrm{Fe}_{3} \mathrm{O}_{4}\right)$, o $\mathrm{ZnO}$ pode formar soluções sólidas com estes óxidos de ferro $\left(\mathrm{Fe}_{2} \mathrm{O}_{3}, \mathrm{Fe}_{3} \mathrm{O}_{4}\right.$ e $\left.\mathrm{FeO}\right)$, formando facilmente soluções sólidas, tais como $(\mathrm{Mn}, \mathrm{Fe}) \mathrm{Fe}_{2} \mathrm{O}_{4}$. Pela ação das bolhas de $\mathrm{CO}$ geradas no interior do metal líquido, estes óxidos podem ser atomizados e originar partículas de espinélios, como por exemplo, (Mn, Zn, $\mathrm{Fe}) \mathrm{Fe}_{2} \mathrm{O}_{4}$

Tsujino $^{[28]}$ e Nedar ${ }^{[29]}$, em seus estudos afirmam que o principal mecanismo de formação da poeira em conversores ocorre pela ejeção de partículas de metal líquido e da escória, sendo que a volatilização de elementos contidos no banho é mais ativa no último estágio de sopro.

Nedar, Lindbom e Bkorkman ${ }^{[30]}$, mais tarde, chegaram às seguintes conclusões: (a) o mecanismo de vaporização que ocorre na zona de impacto da lança de oxigênio é importante principalmente para aqueles elementos que apresentam alta pressão de vapor; (b) a oxidação de Zn é afetada pela pressão parcial de oxigênio presente em tubulações condutoras de gases, sendo que a condensação de $\mathrm{Zn}$ está provavelmente ocorrendo sobre as partículas ejetadas; (c) há possibilidade de separação de elementos volatilizados por meio do uso de sistemas de coleta que operem em temperaturas do aço líquido.

Neigebauer, Gumennyi e Dmitrienko ${ }^{[31]}$ estudaram o mecanismo da formação de poeira gerada em forno elétrico a arco durante a injeção de oxigênio e concluíram que as partículas foram, em sua maioria, produzidas pela ejeção, sendo o mecanismo de vaporização de importância secundária. 
Mantovani $^{[7]}$ relatou que os seguintes mecanismos podem contribuir para a geração de poeiras tanto em fornos elétricos a arco como em conversores a oxigênio.

- vaporização de metais não ferrosos ( $\mathrm{Zn}, \mathrm{Cd}, \mathrm{Pb}$, entre outros);

- ejeção de gotas de aço líquido;

- ejeção de partículas oriundas da escória

- arraste de materiais adicionados ao forno;

\subsubsection{Propriedades físicas da poeira de aciaria elétrica}

Vargas, Masuero e Vilela ${ }^{[32]}$ e Brehm ${ }^{[33]}$ obtiveram resultados de análises de massa específica de poeira de aciaria que mostram um valor de $4,44 \mathrm{~g} / \mathrm{cm}^{3}$ e em relação à granulometria, o resíduo apresentou diâmetro médio de $0,83 \mu \mathrm{m}$.

Mantovani, Takano e Cavallante ${ }^{[34]}$ caracterizaram três diferentes poeiras geradas em fornos elétricos a arco. Como resultados, encontraram densidade da poeira entre $2,96 \mathrm{~g} / \mathrm{cm}^{3}$ e $3,76 \mathrm{~g} / \mathrm{cm}^{3}$ e área superficial entre $0,59 \mathrm{~m}^{2} / \mathrm{g}$ e $5,09 \mathrm{~m}^{2} / \mathrm{g}$.

Pureza $^{[35]}$, em seu estudo encontrou área superficial específica da amostra de pó de aciaria, medida pelo método BET, um valor igual a 4,72 $\mathrm{m}^{2} / \mathrm{g}$, este estudo também mostrou que 50\% das partículas do resíduo estavam abaixo de $0,66 \mu \mathrm{m}$.

Florêncio $^{[36]}$ relata para a poeira de aciaria, devido as suas características, principalmente a granulometria, a mesma pode ser facilmente transportada pelo vento. A operação de manuseio e armazenagem também é 
dificultada devido às características da granulometria e da área superficial específica.

\subsubsection{Composição química e mineralógica da poeira de aciaria elétrica}

Em função das diferenças nas composições dos vários tipos de poeiras geradas em aciarias, qualquer processo ou estratégia de reciclagem deve distinguir as poeiras geradas em aciarias que vão desde a produção de aços carbono, passando por aços ligados e chegando aos aços altamente ligados e aços inoxidáveis ${ }^{[7]}$.

Com relação ao processo de produção de aço em aciaria elétrica, as poeiras podem ser classificadas de duas formas, de acordo com a quantidade de zinco $^{[1]}$ :

- poeira com alto teor de zinco: acima de $15 \%$ de $\mathrm{Zn}$

- poeira com baixo teor de zinco: abaixo de $15 \%$ de $\mathrm{Zn}$

Em fornos elétricos a arco como em conversores a oxigênio, a composição química das poeiras produzidas é bastante variável, sabe-se que a composição química da poeira gerada depende do tipo de aço a ser produzido, natureza e a quantidade de sucata e adições que constituem parte da carga dos fornos ou conversores ${ }^{[37]}$.

A Tabela 1, apresenta alguns elementos presentes em poeiras de aciaria elétrica, pode-se observar nesta tabela, um fato bem conhecido de que poeiras oriundas de aciarias produtoras de aço carbono tendem a ser mais ricas em $\mathrm{Zn}$ e $\mathrm{Pb}$, devido ao fato deste aço passar por um processo de galvanização ao passo que as siderúrgicas que produzem aço inoxidável, geram uma poeira 
com teores menores destes dois metais, porém com teores maiores em $\mathrm{Cr}$ e $\mathrm{Ni}$, elementos estes que fazem parte da composição química do aço inoxidável.

Tabela 1. Intervalo de composição química para alguns elementos presentes em poeiras de aciaria de siderúrgicas americanas ${ }^{[37]}$.

\begin{tabular}{ccc}
\hline $\begin{array}{c}\text { Elementos } \\
\text { (\% em peso) }\end{array}$ & $\begin{array}{r}\text { Poeira de Aciaria Elétrica } \\
\text { (aço carbono) }\end{array}$ & $\begin{array}{c}\text { Poeira de Aciaria Elétrica } \\
\text { (aço inoxidável) }\end{array}$ \\
\hline $\mathrm{Fe}_{\text {total }}$ & $24,9-46,9$ & $22,2-35,9$ \\
$\mathrm{Zn}$ & $11,12-26,9$ & $1,77-6,22$ \\
$\mathrm{~Pb}$ & $1,09-3,81$ & $0,23-0,78$ \\
$\mathrm{Cd}$ & $0,03-0,15$ & $0,006-1,79$ \\
$\mathrm{Ni}$ & $0,06-0,58$ & $2,01-10,1$ \\
$\mathrm{Cr}$ & $0,01-0,12$ & $0,15-3,34$ \\
$\mathrm{Mo}$ & $<0,02-0,08$ & $0,37-1,46$ \\
$\mathrm{Mn}$ & $2,46-4,60$ & $2,36-4,59$ \\
$\mathrm{Mg}$ & $0,77-2,93$ & $1,70-4,74$ \\
$\mathrm{Cu}$ & $0,06-2,32$ & $0,09-1,26$ \\
$\mathrm{Ca}$ & $1,85-10,0$ & $1,76-6,93$ \\
$\mathrm{Si}$ & $1,35-2,49$ & $1,36-4,83$ \\
$\mathrm{Cl}$ & $0,51-2,36$ & $0,47-1,17$ \\
$\mathrm{~F}$ & $0,01-0,88$ & $1,36-4,83$ \\
$\mathrm{~K}$ & $0,06-1,12$ & $0,80-5,07$ \\
$\mathrm{Na}$ & $0,29-2,31$ & $0,47-4,60$ \\
\hline
\end{tabular}

Mantovani $^{[7]}$, ao estudar três tipos de poeiras de aciaria elétrica geradas m usinas diferentes encontrou teores de ferro que variaram de 29,79 a $48,75 \%$ e teores de óxido de zinco que variaram de 13,5 a 33,7\%.

Nolasco Sobrinho ${ }^{[6]}$ ao analisar poeiras geradas no processo de fabricação de aço inoxidável em aciarias brasileiras obteve resultados para o teor de ferro que variavam de 19,10 a $53,50 \%$ e para o teor de zinco variando entre 0,05 a $1,12 \%$. O teor de ferro é superior e o teor de zinco é inferior quando comparado com os valores das siderúrgicas americanas.

Machado $^{[38]}$ em seus estudos, ao analisar a poeira de aciaria elétrica obteve o resultado do teor de hematita $\left(\mathrm{Fe}_{2} \mathrm{O}_{3}\right)$ de $60,72 \%$ e resultado do teor de zinco de $22,20 \%$.

Silva ${ }^{[1]}$ obteve como resultado da análise da poeira de aciaria elétrica teor de ferro de $42 \%$ e teor de zinco de $13,4 \%$. 
Brehm ${ }^{[33]}$ analisando a poeira de aciaria elétrica da siderúgica Gerdau aços finos Piratini, encontrou valores para o teor de ferro entre 31 e $41 \%$ e valores para o teor de zinco entre 9 e $13 \%$.

Telles, Espinosa e Tenório ${ }^{[39]}$ encontraram na amostra de poeira de aciaria elétrica, teor de $\mathrm{Fe}_{2} \mathrm{O}_{3}$ de $58,3 \%$ e teor de óxido de zinco de $14,2 \%$. Observa-se que os teores de ferro e zinco das siderúrgicas brasileiras produtoras de aço carbono são similares aos teores de ferro e zinco das siderúrgicas americanas.

\subsubsection{Processo para tratamento de poeiras de aciaria elétrica}

Os processos para tratamento das poeiras de aciaria que visam a recuperação de alguns elementos de interesse ( $\mathrm{Zn}, \mathrm{Pb}, \mathrm{Cd}, \mathrm{Cr}$ e Ni) podem ser classificados em processos pirometalúrgicos ou hidrometalúrgicos ${ }^{[7]}$. Processos onde não ocorre a recuperação de elementos químicos que possam ser posteriormente comercializados são classificados como processo de estabilização química ou vitrificação ${ }^{[1]}$.

O processo $W_{a e l}{ }^{[40]}$, é processo pirometalúrgico mais utilizado para tratamento e recuperação de zinco da PAE sendo considerado pela indústria como o melhor processo para a recuperação e reciclagem da PAE contendo zinco superior a $15 \%$, processa $75 \%$ da PAE tratada no mundo ${ }^{[41]}$. A operação consiste em misturar a poeira de aciaria elétrica, carvão e fundentes. Em seguida esta carga é introduzida no forno, à medida que o forno gira ocorre a secagem da carga, os haletos e álcalis são volatizados, os óxidos de ferro são parcialmente reduzidos, os óxidos de zinco são reduzidos e volatilizados. 0 
produto resultante contém até $68 \% \mathrm{Zn}$ contaminado por chumbo e elementos halogênios e um outro produto com alto teor de ferro, que não é tóxico ${ }^{[40]}$.

O processo Flame Reactor ${ }^{[40]}$, requer a alimentação de PAE e oxigênio para reagir com o coque ou carvão utilizado como redutores. Neste processo ocorre a fusão da carga. Os produtos obtidos consistem em um óxido de zinco impuro e uma escória rica em ferro que atende os requisitos para ser descartada ou utilizada em pavimentação de rodovias.

O processo ZTT Ferrolime ${ }^{[40]}$ é um processo no qual a PAE é pelotizada e tratada em um forno rotativo, utilizando como redutor carvão ou coque. Resulta em um óxido de zinco que contém várias impurezas, além de um material rico em ferro, parcialmente reduzido, podendo este material ser alimentado no forno elétrico, contribuindo para o aumento do rendimento metálico.

O processo Laclede Stee ${ }^{[40]}$ é um processo pirometalúrgico que consiste em misturar a PAE junto com o redutor, e injetar na região que se forma o plasma. Os vapores gerados (constituídos de $\mathrm{Zn}, \mathrm{Pb}$ e $\mathrm{Cd}$ ) são condensados. Tem-se ainda a geração de escória rica em ferro.

O processo Sirosmelt ${ }^{40]}$ opera mediante fusão e redução em que oxigênio, redutor e PAE são injetados por meio de uma lança em direção a uma escória. Os vapores são coletados por filtros de manga. A escória gerada é levada até um segundo forno e em seguida é injetado novamente redutor, com o intuito de reduzir os óxidos de zinco e chumbo contidos nessa escória.

O processo Enviroscience Met Woo ${ }^{40]}$ opera com PAE e fundentes briquetados. Após o tempo de cura, os briquetes são levados até um forno de 
cuba onde são carregados junto com redutor. Neste processo são produzidos ferro gusa e óxido de zinco contaminado com chumbo.

O processo Enviroplas ${ }^{[40]}$ opera primeiramente com a remoção dos halogêneos $(\mathrm{Cl}$ e $\mathrm{F})$, após esta etapa o material é misturado com redutor carbonáceo e carregado no forno. Os gases produzidos são guiados ao condensador em para produzir Zn metálico. Como produto da fusão, tem-se a geração de uma escória inerte.

O processo FASTMET ${ }^{[42]}$ é uma tecnologia para reciclagem de PAE que se baseia na fusão em um forno de soleira rotativa. As pelotasde PAE previamente produzidas e alimentadas no forno são reduzidas, o zinco e outros elementos voláteis, também são reduzidos e são volatilizados com os gases de combustão. Tem-se no final da operação um material que contem $30-70 \%$ de ferro com um grau de metalização de 75-94\%. Como sub-produto tem-se o óxido de zinco que contém entre $50-65 \%$ de zinco. Este processo apresenta como desvantagem o alto consumo de gás combustível.

O processo PRIMUS ${ }^{[43]}$ é bem adaptado para processar PAE que contenha mais que $5 \%$ de zinco. 0 processo produz ferro gusa de qualidade semelhante ao produzido por um alto forno, um concentrado de óxido de zinco com mais de 55\%de zinco e uma escória inerte. O processo Primus opera em duas etapas: primeiro secagem / aquecimento / pré-redução e em seguida redução final / fusão, combinando um forno de múltiplas soleiras e um forno elétrico a arco.

O processo Zincex ${ }^{[40]}$ modificado (hidrometalúrgico) inicia com a lixiviação da PAE através de ácido sulfúrico para solubilizar os óxidos de Zn, 
Cd e haletos. Através da eletrólise é obtido zinco metálico de alta pureza e o ácido sulfúrico gerado retorna para etapa de lixiviação.

O processo Ezinex ${ }^{[40]}$ (hidrometalúrgico) tem início com a lixiviação da PAE com com cloreto de amônia para solubilizar os óxidos de $\mathrm{Zn}, \mathrm{Pb}$ e $\mathrm{Cd}$. Em seguida o material é filtrado e submetida à eletrólise para obter zinco. 0 resíduo da lixiviação é secado e pelotizado com carvão para retornar para o forno elétrico a arco.

Autores $^{[44,45,46 \text { e } 47]}$ realizaram estudos para tratar a PAE através de processos hidrometalúrgicos com o objetivo de recuperar os elementos químicos tais como chumbo e zinco, porém, os processos hidrometalúrgicos apresentam dificuldade de lixiviação da ferrita de zinco e dificuldades na separação sólido/líquido.

\subsection{NORMALIZAÇÃO BRASILEIRA SOBRE RESÍDUOS}

A associação Brasileira de Normas Técnicas (ABNT), considerando a crescente preocupação da sociedade com relação às questões ambientais e ao desenvolvimento sustentável, criou a CEET-00.01.34 - Comissão de Estudo Especial Temporária de Resíduos Sólidos, para revisar a ABNT NBR 10004:1987- Resíduos sólidos - Classificação, visando a aperfeiçoá-la e, desta forma, fornecer subsídios para o gerenciamento dos resíduos sólidos. Esta revisão gerou a norma ABNT NBR 10004:2004 ${ }^{[2]}$ - Resíduos sólidos Classificação.

As justificativas estabelecidas para a revisão foram a correção, complementação e a atualização da norma em vigor e a desvinculação do 
processo de classificação em relação apenas à disposição final de resíduos sólidos.

A norma ABNT NBR 10004:2004 ${ }^{[2]}$ faz referências normativas às normas ABNT NBR 10005:2004 ${ }^{[48]}$ - Procedimento para obtenção de extrato lixiviado de resíduos sólidos; ABNT NBR 10006:2004 ${ }^{[49]}$ - Procedimento para obtenção de extrato solubilizado de resíduos sólidos e ABNT NBR 10007:2004 ${ }^{[50]}$ Amostragem de resíduos sólidos. Estas normas contêm disposições que ao serem citadas, constituem prescrição para a norma ABNT NBR 10004:2004.

A norma ABNT NBR 10004:2004 ${ }^{[2]}$ apresenta as definições de resíduo sólido, periculosidade de um resíduo, toxicidade, agente tóxico, toxicidade aguda, agente teratogênico, agente mutagênico, agente carcinogênico e agente ecotóxico.

A norma ABNT NBR 10004:2004 ${ }^{[2]}$ apresenta ainda a classificação dos resíduos, classificando-os em:

a) resíduos classe I - perigosos;

b) resíduos classe II - não perigosos; sendo que nesta classe há uma subdivisão em resíduos classe II A - Não inertes e classe II B - Inertes.

A classificação de resíduos sólidos envolve a identificação do processo ou atividade que Ihes deu origem, de seus constituintes e características, e a comparação destes constituintes com listagens de resíduos e substâncias cujo impacto à saúde e ao meio ambiente é conhecido.

Seguindo as orientações desta norma, a amostra da poeira de aciaria elétrica gerada em uma siderúrgica no estado do Espírito Santo ${ }^{[51]}$, cujo resultado da composição química apresenta teor de chumbo de 1,48\% e teor de cádmio de $0,03 \%$ é classificada pela ABNT NBR 10004:2004 ${ }^{[2]}$, anexo B 
como resíduo perigoso de fonte específica, fonte gerador: Ferro e aço e código de identificação: K061, característica de periculosidade: tóxico, devido à presença de chumbo e de cádmio.

O resultado do ensaio de lixiviação de uma amostra de PAE realizada por Fuessle e Taylor ${ }^{[52]}$, apresentou para cádmio lixiviado 7,00mg/litro e para chumbo lixiviado $6,30 \mathrm{mg} /$ litro. Estes valores excedem os valores de limite máximo prescritos na norma ABNT NBR 10004:2004 ${ }^{[2]}$, anexo F, que são de $1,0 \mathrm{mg} / \mathrm{litro}$ para cádmio e 5,0 mg/litro para chumbo, sendo esta amostra de PAE considerada um resíduo perigoso. Para o ensaio de solubilização, o anexo G estabelece que o limite máximo no extrato é de $0,005 \mathrm{mg} /$ litro para bário e $0,01 \mathrm{mg} / \mathrm{litro}$ para o chumbo.

\section{$2.3 \quad \mathrm{ZINCO}$}

O zinco é um metal do grupo dos não ferrosos, de cor branco-azulada, forma cristalina hexagonal compacta, número atômico: 30, peso atômico: 65,38 , densidade (a $2^{\circ} \mathrm{C}$ ): 7,14, dureza: 2,5 (escal a de Mohs), ponto de fusão: $419{ }^{\circ}$ (à pressão de $760 \mathrm{~mm}$ de $\mathrm{Hg}$ ) e ponto de ebuliçã o: $907^{\circ} \mathrm{C}^{[53,54,55]}$.

Em solos, frequentemente permanece fortemente sorvido e no ambiente aquático se prende predominantemente ao material suspenso antes de se acumular no sedimento ${ }^{[1]}$.

O principal uso de zinco é no processo de galvanização, tanto na produção de chapas zincadas pelas siderúrgicas, como em galvanoplastias para acabamento e proteção anticorrosiva de peças metálicas ${ }^{[56]}$.

Com relação à utilização de chapas galvanizadas no mercado automobilístico brasileiro, a tendência é que aumente ainda mais, seguindo os 
padrões internacionais da indústria, pois o desenvolvimento tecnológico possibilitou a pintura de chapas galvanizadas de boa qualidade e que oferecem vantagem em relação a custos e qualidade ${ }^{[53,56]}$.

O aumento da garantia contra a corrosão dos veículos tem forçado as montadoras a substituir as chapas laminadas a frio e galvanizadas pelo processo eletrolítico por chapas galvanizadas pelo processo de galvanização a quente, o qual oferece uma maior proteção, empregando quatro vezes mais zinco que o processo eletrolítico ${ }^{[56]}$.

Esta substituição tem como consequência o aumento da quantidade de zinco na sucata que alimenta o forno elétrico, o que contribui para uma maior concentração do zinco na poeira gerada durante a produção do aço ${ }^{[57]}$.

O zinco é utilizado também como matéria-prima para ligas metálicas como latões, bronzes e as ligas zamac (zinco alumíniomagnésio), além de ser usado em pigmentos, pilhas secas, produtos farmacêuticos e cosméticos, micronutrientes para o homem, animais e plantas e materiais de construção ${ }^{[58,59]}$.

Seu ponto de fusão facilita a moldagem em peças injetadas e centrifugadas. Seu ponto de ebulição facilita a sua extração e refino e, por ser maleável entre 100 e $150^{\circ} \mathrm{C}$, pode ser laminado em chapas e estirado em fios $^{[59,60]}$.

O zinco é classificado em duas grandes famílias: o zinco primário e zinco secundário (obtido através de sucatas e resíduos). O zinco primário representa de $80,0 \%$ a $85,0 \%$ da produção atual, e o seu principal processo de produção é o eletrolítico, que consiste na dissolução do óxido ustulado em ácido sulfúrico, seguido de um processo de eletrólise, na qual o eletrólito, rico em zinco, entra 
em células eletrolíticas com anodos de ligas de zinco e catodos de alumínio. 0 zinco se deposita nos catodos de alumínio, sendo periodicamente retirado para posterior fusão e transformação em placas ${ }^{[53]}$.

Entre os metais não ferrosos o consumo mundial de zinco só é superado pelo consumo do alumínio e pelo consumo do cobre ${ }^{[8]}$.

\subsubsection{Produção do zinco}

O zinco é encontrado na natureza principalmente sob a forma de sulfetos, associado ao chumbo, cobre, prata e ferro (galena, calcopirita, argentita e pirita, dentre outros). O minério sulfetado de zinco está sujeito a grandes transformações na zona de oxidação formando óxidos, carbonatos e silicatos. As mineralizações ocorrem, principalmente, nas rochas calcárias que são as hospedeiras usuais ${ }^{[53]}$.

Os principais minerais de zinco são a blenda ou esfalerita (ZnS), willemita $\left(\mathrm{Zn}_{2} \mathrm{SiO}_{4}\right)$, smithsonita $\left(\mathrm{ZnCO}_{3}\right)$, calamina ou hemimorfita $\left(2 \mathrm{ZnO} . \mathrm{SiO}_{2} \cdot \mathrm{H}_{2} \mathrm{O}\right)$, wurtzita $(\mathrm{Zn}, \mathrm{Fe}) \mathrm{S}$, franklinita $(\mathrm{Z}, \mathrm{n}, \mathrm{Mn}) \mathrm{Fe}_{2} \mathrm{O}_{4}$, hidrozincita $\left[2 \mathrm{ZnO}_{3} \cdot 3 \mathrm{Zn}(\mathrm{OH})_{2}\right]$ e zincita $(\mathrm{ZnO})$, com destaque no caso do Brasil para os minérios calamina, willemita e esfalerita ${ }^{[59]}$.

Existem dois processos básicos de obtenção do zinco, o processo pirometalúrgico e 0 processo hidrometalúrgico; sendo 0 processo hidrometalúrgico responsável por $80 \%$ da produção no mundo em $1995^{[61]}$, tornou-se responsável por $85 \%$ da produção mundial 10 anos depois $^{[62]}$.

No processo pirometalúrgico ${ }^{[63]}$, o concentrado de zinco, quando sulfetado, é submetido inicialmente à ustulação oxidante na presença de oxigênio, obtendo-se óxido de zinco e $\mathrm{SO}_{2}$. Em seguida é aglomerado e 
carregado com coque em alto-forno produzindo-se vapor de zinco que é condensado para obtenção do zinco metálico com cerca de $98 \%$ de pureza. Se a pureza desejável para o zinco for $99,5 \%$, este é então submetido ao processo de refino, que consiste em nova ebulição para formação de vapor de zinco e posterior condensação, obtendo-se zinco com 99,95\% de pureza ${ }^{[64]}$.

O processo hidrometalúrgico ${ }^{[63]}$, consiste em obter uma solução de sulfato de zinco e em precipitar o zinco metálico da solução, através de eletrólise. O processo compreende as seguintes etapas:

1 - Ustulação do concentrado sulfetado para transformá-lo o sulfeto em óxido, que é solúvel em ácido.

2 - Lixiviação do material oxidado obtido com ácido sulfúrico, para obtenção de solução de sulfato de zinco.

3 - Purificação da solução de sulfato de zinco, sendo o método mais utilizado o da adição de pó de zinco para precipitação de impurezas como cobre, cádmio, cobalto e níquel.

4 - Eletrólise da solução de sulfato de zinco com regeneração do ácido, ácido este que é reutilizado na lixiviação.

5- Refusão dos cátodos $(99,99 \%$ de pureza) para produção do zinco nas formas usuais de lingotes ou placas.

As seis principais tecnologias existentes para a produção do zinco ${ }^{[64]}$ são brevemente relatadas:

1- Ustulação-Lixiviação-Eletrólise (RLE), consiste na ustulação do concentrado sulfetado, seguida de uma lixiviação atmosférica, da remoção de impurezas e da eletrorrecuperação do metal. Tem como uma grande vantagem a obtenção do metal com elevado grau de pureza. 
2 - Forno Imperial Smelting (ISF), consiste em tratar concentrados de zinco e chumbo por processo pirometalúrgico. A qualidade do zinco obtido é inferior àquela obtida pelo processo RLE.

3 - Lixiviação Direta Atmosférica (ZDL - Zinc Direct Leaching), consiste em tratar o concentrado sulfetado com solução rica em ferro (III) proveniente da lixiviação ácida do circuito RLE, para se obter diretamente a solução de sulfato de zinco.

4 - Lixiviação Sob Pressão (ZPL - Zinc Pressure Leaching), diferencia-se da tecnologia de lixiviação direta pelo processamento das reações em vasos de pressão e pelo consumo de oxigênio com $98 \%$ de pureza.

5 - Integrado Silicato-Sulfeto, Os concentrados, obtidos a partir dos circuitos de minério sulfetado e silicatado, alimentam a etapa de lixiviação do circuito RLE 6 - Zincex Modificado (MZP - Modified Zincex Process), caracteriza-se pela inclusão da etapa de extração por solventes para purificação do licor concentrado obtido a partir da lixiviação ácida de minérios oxidados de zinco, seguida de neutralização com dolomita, extração por solventes (normalmente D2EHPA e querosene), eletrólise e fundição.

A produção nacional de zinco tem início com a realização do desmonte do minério das minas, com um teor metálico que varia entre $3,6 \%$ a $20,0 \%$. Depois de submetido a sucessivas britagens, o minério é moído e posteriormente passa pelo processo de flotação e filtragem para a obtenção do concentrado, cujo teor de zinco já alcança 45,0\%. E só então é convertido pelo processo de lixiviação química (hidrometalurgia), seguida de deposição eletrolítica, em lingote de metal do tipo SHG (Special High Grade) com teor de zinco maior ou igual a $99,99 \%{ }^{[53]}$. 


\subsubsection{Oferta mundial de zinco}

Os preços do zinco, referenciados pela Bolsa de Metais de Londres

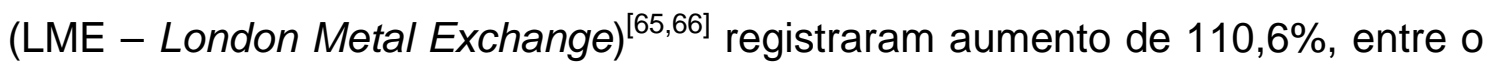
início de janeiro de 2009 (US\$/t 1.220,00) e final de dezembro de 2009 (US\$/t $2.569,00$ ), contrastando com as quedas de $11,7 \%$ e $48,8 \%$, respectivamente, ocorridas em relação aos preços médios praticados em 2008 e 2007. O avanço ocorrido no decorrer de 2009 deve-se principalmente à demanda chinesa.

Neste ano, Austrália, Canadá, Cazaquistão, China e Estados Unidos, detinham mais de $70 \%$ das reservas mundiais de minérios de zinco. As reservas nacionais estimadas em 1,6 milhões ocorrem principalmente nos estados de Minas Gerais e Mato Grosso ${ }^{[53]}$.

Os principais produtores mundiais de zinco são China, Peru, Austrália, Canadá, Estados Unidos e Índia, que respondem por cerca de $69 \%$ da produção mundial de 2009. O Brasil, neste ano, contribuiu com apenas 1,6\% dessa produção mundial ${ }^{[53]}$.

\subsection{PRODUÇÃO DE FERRO GUSA E AÇO}

\subsubsection{Produção de ferro gusa em alto forno}

O alto forno é um equipamento dominante na cenário mundial de produção de ferro gusa líquido com qualidade e em quantidade necessárias para o bom andamento dos processos seguintes (fabricação do aço ${ }^{[67]}$.

É um de forno de cuba através do qual, pela fusão redutora de minérios de ferro em presença de carvão vegetal ou coque e fundente, os quais são 
carregados no topo e, na descida, são transformados pela ação dos gases ascendentes, provenientes da combustão incompleta do carvão com o oxigênio soprado pelas ventaneiras, obtendo-se escória e ferro gusa líquidos pelo cadinho e poeiras e gases no topo do forno ${ }^{[68]}$.

A Figura 5 apresenta detalhes do perfil do alto forno.

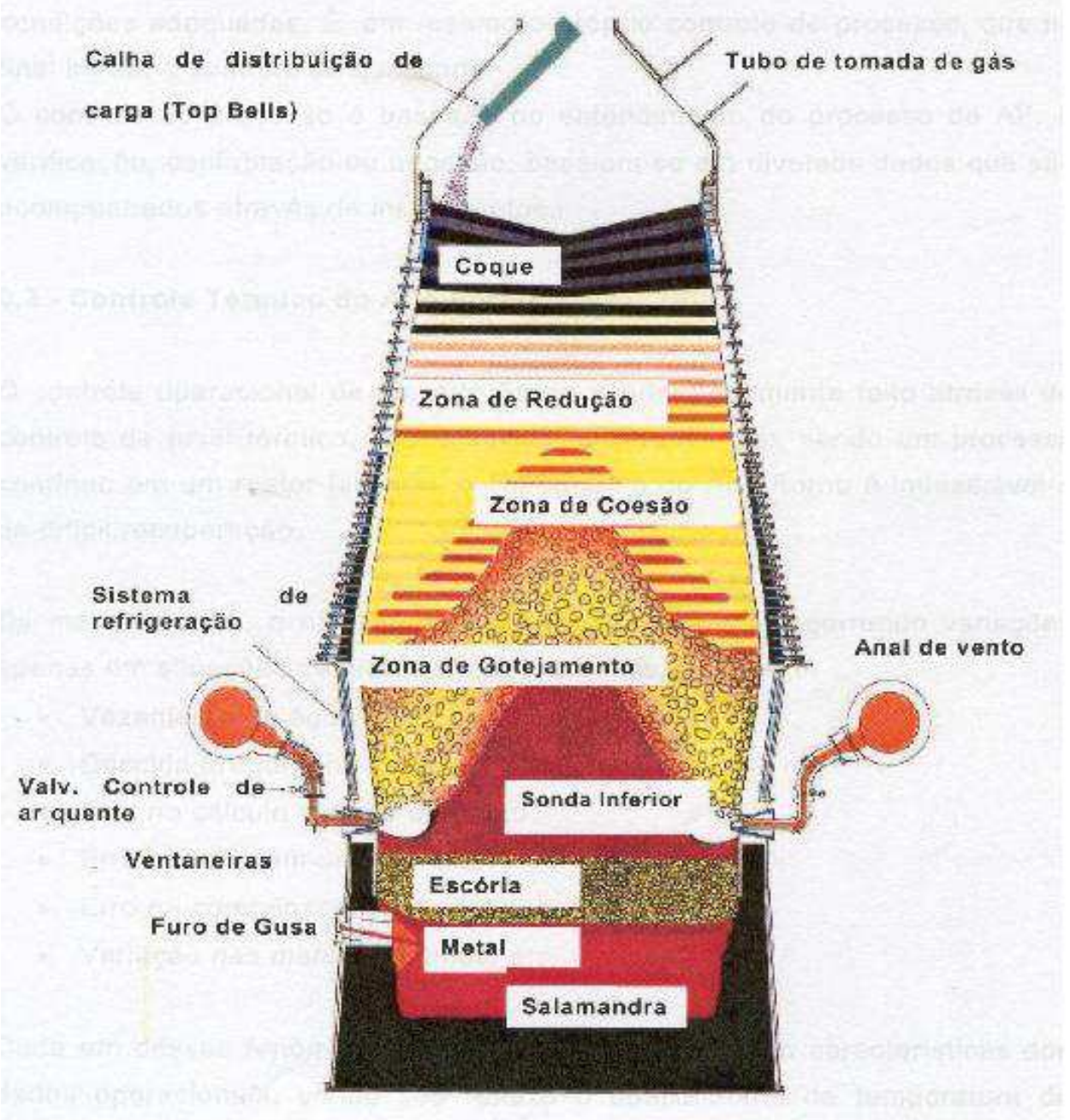

Figura 5. Perfil do alto forno ${ }^{[69]}$.

Em um alto forno, o ferro gusa é o principal produto e o gás de topo, pó de alto forno e escória, são recuperados como subprodutos ${ }^{[70]}$.

O ferro gusa é dividido em gusa para aciaria, gusa para fundição e gusa para ligas $^{[70]}$. 
O gás de Alto Forno contém de 21 a $25 \%$ de $\mathrm{CO}, 18$ a $22 \%$ de $\mathrm{CO}_{2}, 2$ a $5 \%$ de $\mathrm{H}_{2}$ possuindo 700 a $800 \mathrm{kcal} / \mathrm{Nm}^{3}$ de poder calorífico; é recuperado e usado como combustível ${ }^{[70]}$.

O pó de alto forno é recolhido no sistema de limpeza de gases. A composição de pó varia de acordo com a matéria prima usada, porém, aproximadamente é composto por 25 a $40 \%$ de ferro; 40 a $45 \%$ de C; 5 a $7 \%$ de $\mathrm{SiO}_{2}$ e 2 a $4 \%$ de $\mathrm{CaO}^{[70]}$.

A quantidade de escória produzida é normalmente 250 a $340 \mathrm{~kg} / \mathrm{t}$ de gusa. A escória é um subproduto que na forma de escória bruta é utilizada em aterros e escória granulada utilizada na fabricação de cimento ${ }^{[70]}$.

Internamente, o alto forno é subdividido em 5 principais zonas (zona granular, zona coesiva, zona de gotejamento, zona de combustão e cadinho) ${ }^{[67]}$.

A zona granular é a região onde o minério e coque descem como carga sólida, ela engloba a zona de reserva térmica e química. Inicialmente, o mineral de hematita $\left(\mathrm{Fe}_{2} \mathrm{O}_{3}\right)$ é reduzido a magnetita $\left(\mathrm{Fe}_{3} \mathrm{O}_{4}\right)$ pela ação do gás reduto CO logo após o carregamento no topo. Durante a descida de carga, ainda na cuba a magnetita continua reagindo com o $\mathrm{CO}$ formando então 0 óxido de ferro wustita (FeO). Finalmente, por volta de $1000^{\circ} \mathrm{C}$, logo no início da zona coesiva, a wustita reduz a ferro metálico ${ }^{[70]}$.

A zona coesiva $\left(1000\right.$ a $\left.1450^{\circ} \mathrm{C}\right)$ é a região em que os minérios amolecem e fundem, a camada de coque permanece sólida permitindo o escoamento do fluxo gasoso para as partes superiores (cuba) do alto forno (janelas de coque). Tem-se a formação de ferro metálico e escória primária líquida com baixo ponto de fusão $\left(1300^{\circ} \mathrm{C}\right)$ e com alto teor de $\mathrm{FeO}$, até $40 \%{ }^{[70]}$. 
A zona de gotejamento $\left(1400^{\circ} \mathrm{C}\right.$ a $\left.1800^{\circ} \mathrm{C}\right)$ é a região em que o metal e a escória líquidos descem sob um leito poroso de coque em contra corrente com o gás redutor.

$\mathrm{Na}$ zona de gotejamento acontece as reações de redução ${ }^{[70]}$ :

$$
\begin{array}{ll}
\mathrm{FeO}_{(l)}+\mathrm{CO} \rightarrow \mathrm{Fe}_{(l)}+\mathrm{CO}_{2} & \Delta \mathrm{G}^{\circ}=-9655+8,36 \mathrm{~T} \mathrm{cal} / \mathrm{mol} \\
\mathrm{CO}_{2}+\mathrm{C} \rightarrow 2 \mathrm{CO} & \Delta \mathrm{G}^{\circ}=38355-40,34 \mathrm{~T} \mathrm{cal} / \mathrm{mol} \\
\mathrm{P}_{2} \mathrm{O}_{5}+5 \mathrm{CO} \rightarrow 2 \mathrm{P}+5 \mathrm{CO}_{2} & \Delta \mathrm{G}^{\circ}=42595-14,40 \mathrm{~T} \mathrm{cal} / \mathrm{mol} \\
\mathrm{P}_{2} \mathrm{O}_{5}+5 \mathrm{C} \rightarrow 2 \mathrm{P}+5 \mathrm{CO} & \Delta \mathrm{G}^{\circ}=234350-216,1 \mathrm{~T} \mathrm{cal} / \mathrm{mol} \\
\mathrm{SiO}_{2}+2 \mathrm{C} \rightarrow \mathrm{Si}+2 \mathrm{CO} & \Delta \mathrm{G}^{\circ}=85600-95,32 \mathrm{~T} \mathrm{cal} / \mathrm{mol} \\
\mathrm{FeS}+\mathrm{CaO}+\mathrm{C} \rightarrow \mathrm{CaS}+\mathrm{CO}+\mathrm{Fe} & \Delta \mathrm{G}^{\circ}=22520-27,93 \mathrm{~T} \mathrm{cal} / \mathrm{mol} \\
\mathrm{FeS}+\mathrm{MnO}+\mathrm{C} \rightarrow \mathrm{MnS}+\mathrm{Fe}+\mathrm{CO} & \Delta \mathrm{G}^{\circ}=362200-33,51 \mathrm{~T} \mathrm{cal} / \mathrm{mol} \\
\mathrm{MnS}+\mathrm{CaO}+\mathrm{C} \rightarrow \mathrm{Mn}+\mathrm{CaS}+\mathrm{CO} & \Delta \mathrm{G}^{\circ}=55650-35,80 \mathrm{~T} \mathrm{cal} / \mathrm{mol}
\end{array}
$$

Para a reação global $\mathrm{SiO}_{2}+2 \mathrm{C} \rightarrow \mathrm{Si}+2 \mathrm{CO}(5)$, dois mecanismos para a transferência do Si para o gusa devem ser considerados ${ }^{[68,69,71]}$.

$$
\begin{array}{lr}
\mathrm{SiO}_{2}+\mathrm{C} \rightarrow \mathrm{SiO}_{(\mathrm{g})}+\mathrm{CO} & \Delta \mathrm{G}^{\circ}=162300-79,36 \mathrm{~T} \mathrm{cal} / \mathrm{mol} \\
\mathrm{SiO}_{2}+\underline{\mathrm{C}} \rightarrow \mathrm{SiO}_{(\mathrm{g})}+\mathrm{CO} & \Delta \mathrm{G}^{\circ}=185150-68,68 \mathrm{~T} \mathrm{cal} / \mathrm{mol}
\end{array}
$$

Estudos cinéticos de vários autores, concluíram que a reação (5) é muito lenta para justificar os teores de silício encontrados no ferro gusa, portanto, concluíram que a transferência de silício via SiO, reações (9) e (10) é o principal caminho de transferência de silício para o ferro gusa ${ }^{[68,69,71]}$.

A zona de combustão $\left(2000^{\circ} \mathrm{C}\right)$ é a região em que o ar quente soprado pelas ventaneiras, na parte superior do cadinho, faz o coque ou carvão vegetal 
entrar em combustão elevando a temperatura acima de $1900{ }^{\circ} \mathrm{C}$ e os gases resultantes sobem aquecendo toda a carga ${ }^{[70]}$.

A zona do cadinho é a região em que o gusa e a escória líquidos e o coque ou carvão vegetal se acumulam num recipiente refratário ${ }^{[70]}$.

\subsubsection{Produção de aço em forno elétrico a arco}

Em 1878, Wilhelmvon Siemens, em suas experiências com caráter científico, fundiu aço pela primeira vez em um cadinho utilizando arco voltaico $^{[67]}$. No ano seguinte, Paul Heroult obteve patente para um forno elétrico $\operatorname{arco}{ }^{[19]}$.

A flexibilidade de controlar a temperatura do banho e as condições de oxidação e redução da escória, contribuíram para o reconhecimento do forno elétrico a arco como um equipamento versátil de produção do aço, tornando-se nas últimas décadas um dos mais eficientes equipamentos ${ }^{[58,72]}$.

Dentre as vantagens do forno elétrico a arco pode-se citar $^{[72]}$ :

a) Permite produzir qualquer tipo de aço, devido ao controle de aquecimento.

b) É um equipamento versátil, podendo ser carregado com $100 \%$ de carga sólida ou $100 \%$ de carga líquida.

c) Opera intermitentemente e permite alterações de produção.

d) Proporciona alta eficiência energética.

O número crescente de fornos elétrico a arco sendo instalados e a tendência de instalações de fornos com capacidade de produção entre 200 e 250 toneladas mostram a importância deste equipamento. Outro fator importante, é o aumento do emprego de aços ligados com $\mathrm{Cr}, \mathrm{Ni}, \mathrm{Ti}, \mathrm{V}, \mathrm{B}$ e Mo 
(denominados aços alta liga) cuja produção em fornos elétricos a arco se torna mais econômica do que em conversores a oxigênio ${ }^{[72]}$.

Nos fornos elétricos a arco, há a transformação da energia elétrica em energia térmica. A corrente elétrica alternada, passa por transformadores que baixam a voltagem para valores entre 80 e $250 \mathrm{~V}$ e é levada aos três eletrodos de grafite. Arcos elétricos são estabelecidos entre os eletrodos através da sucata e a radiação do arco funde a carga ${ }^{[9,72]}$.

No começo da década de $60^{[72]}$, empregavam-se fornos com capacidade de potência de 300 a 400kVA/t, atualmente empregam-se fornos com capacidade de potência de 600 a 750kVA/t, fornos estes denominados UHP (Ultra High Power- Ultra Alta Potência). Quanto maior a potência instalada, mais rápida será a fusão, entretanto, a radiação gerada acelera o desgaste dos refratários da parede e da abóbada do forno. Como consequência para solucionar esta deficiência foram desenvolvidos painéis refrigerados a água e os mesmos foram posicionados na parede do forno. A Figura 6 apresenta os principais desenvolvimentos em aciaria elétrica nas últimas décadas. 


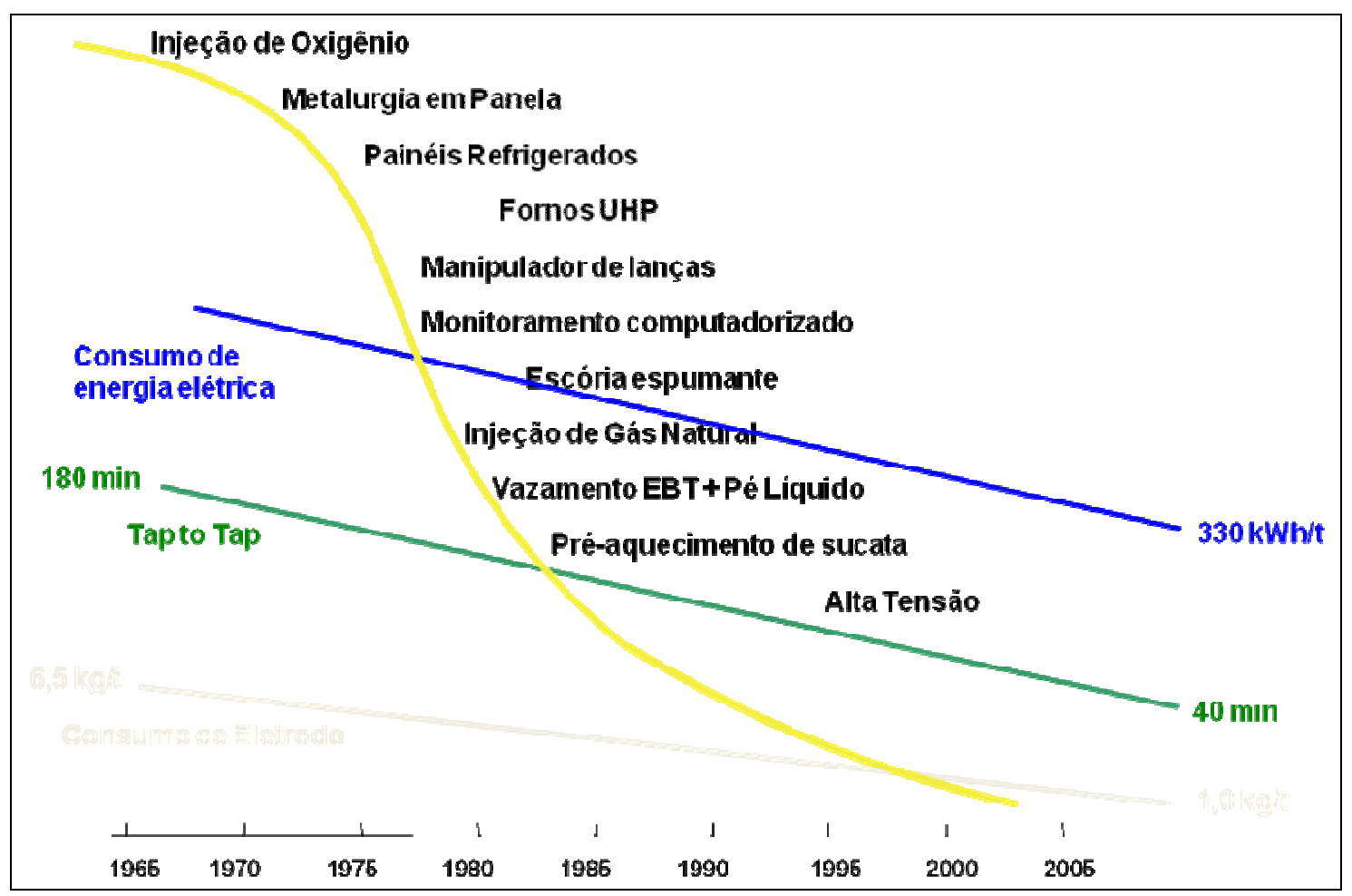

Figura 6. Principais desenvolvimentos em aciaria elétrica ${ }^{[71]}$.

Observa-se na figura que o tempo de corrida reduziu de 180 minutos para 40 minutos em um período de 4 décadas.

A operação do forno elétrico a arco envolve as seguintes fases ${ }^{[9]}$;

a) Carregamento da sucata e fundentes;

b) Fusão em condições oxidantes;

c) Fervura do banho;

d) Retirada da escória;

e) Refino (recarburação, desoxidação e dessulfuração sob uma escória redutora, bem como aquecimento para vazar);

f) Vazamento.

$\mathrm{Na}$ carga de um forno, primeiramente carrega-se a cal. Carrega-se também minério ou carepa de laminação e em seguida faz-se o carregamento 
da sucata. Recomenda-se que o teor de carbono da carga seja $0,30 \%$ maior que o teor do aço desejado para que se possa obter a fervura do banho ${ }^{[9]}$.

Efetuado o primeiro carregamento, recoloca-se a abóbada do forno, fecham-se as portas do mesmo e baixam-se os eletrodos, ligando-se o arco. Inicia-se então a fusão da carga. Conforme a quantidade de aço a ser produzida, outros carregamentos serão necessários. Carregamentos estes que serão efetuados durante a fusão da carga ${ }^{[72]}$.

Desde1947 tem-se utilizado a injeção de oxigênio na carga para acelerar a fusão e a fervura (descarburação) do banho nos fornos elétricos a $\operatorname{arco}^{[9]}$.

A fervura tem como objetivo remover elementos indesejáveis ao aço, tais como, fósforo, nitrogênio e também inclusões ${ }^{[9]}$.

Durante a fervura, o banho absorve oxigênio. A fase de refino destina-se à redução deste teor de oxigênio, à remoção de óxidos que ainda estão no banho para a escória e a completar a dessulfuração. A fase de refino engloba a descarburação, desfosforação, desoxidação e dessulfuração ${ }^{[9,72]}$.

As condições para uma boa dessulfuração são ${ }^{[68,70]}$ :

a) Escória de alta basicidade (teor de óxido de cálcio superior ao óxido de silício).

b) Aço desoxidado.

c) Temperatura próxima de $1660^{\circ} \mathrm{C}$.

Encerrada a fase de refino, a etapa seguinte é o vazamento do aço em panela, panela esta que é encaminhada para o equipamento de refino na panela ou para equipamento de lingotamento. A partir da década de 80 , foram desenvolvidos e colocados em operação, fornos com vazamento pelo fundo (uma válvula gaveta foi instalada excentricamente no fundo do forno), este 
sistema tornou possível vazar o aço na panela sem haver o vazamento de escória. Escória esta que é prejudicial na etapa de refino na panela ou na etapa de lingotamento ${ }^{[72]}$.

\subsection{TERMODINÂMICA DA REDUÇÃO DOS ÓXIDOS DE FERRO E ZINCO}

Com relação às pesquisas de adição de PAE em ferro gusa líquido contendo carbono e/ou silício, de acordo com Pickles ${ }^{[85]}$, muito pouco foi relatado. Nos estudos avaliados pelo referido autor, foram utilizados cadinhos de grafite e uma vez que o carbono participa das reações, os mecanismos de reação se tornam de difícil determinação. A utilização de cadinhos de alumina e uma atmosfera inerte com argônio permitem determinar os mecanismos de reação da PAE com o ferro gusa líquido ${ }^{[88]}$.

A Franklinita $\left(\mathrm{ZnO} . \mathrm{Fe}_{2} \mathrm{O}_{3}\right)$, de presença predominante na PAE, se decompõe-se à temperatura acima de $1227^{\circ} \mathrm{C}$ tendo como produto óxido de zinco $(\mathrm{ZnO})$ e hematita $\left(\mathrm{Fe}_{2} \mathrm{O}_{3}\right)^{[88]}$.

Pickles $^{[88]}$ relata que em um forno à temperatura entre 1400 e $1500^{\circ} \mathrm{C}$, a redução do óxido de ferro contido na poeira, ocorrerá em dois estágios. No primeiro estágio, redução da hematita da PAE pelo ferro contido no banho tendo como produto o óxido de ferro $(\mathrm{FeO})$ e no segundo estágio a redução do óxido de ferro pelo carbono ou silício dissolvido no banho ou pelo monóxido de carbono tendo como produto ferro mais monóxido e dióxido de carbono ou sílica $\left(\mathrm{SiO}_{2}\right)$, ou dióxido de carbono.

É importante relatar que a reação de redução pelo silício apresenta menor valor de energia livre de Gibbs do que a energia das reações 
anteriormente relatadas (redução pelo carbono) e que a reação de redução pelo monóxido apresenta resultado positivo ${ }^{[88]}$.

A redução do óxido de zinco pode ocorrer pelo óxido de ferro; ferro sólido ou líquido; pelo carbono dissolvido no banho ou pelo monóxido de carbono tendo como produto zinco na forma gasosa e hematita; zinco na forma de gasosa e óxido de ferro; zinco na forma gasosa e monóxido de carbono ou dióxido de carbono e zinco na forma gasosa e dióxido de carbono ${ }^{[88]}$.

A redução do óxido de zinco pelo carbono tendo como produto zinco na forma gasosa e monóxido de carbono apresenta menor valor de energia livre de Gibbs do que a energia das reações anteriormente relatadas (redução pelo ferro e pelo monóxido de carbono) e que a reação de redução pelo óxido de ferro tendo como produto zinco na forma gasosa e hematita apresenta resultado positivo do valor de energia livre de Gibbs ${ }^{[88]}$.

O referido autor apresenta três possíveis cenários combinando as reações acima descritas para a redução da poeira de aciaria elétrica mediante adição em ferro gusa líquido contendo carbono e silício.

No primeiro cenário, óxido de zinco $(\mathrm{ZnO})$ combina-se com hematita $\left(\mathrm{Fe}_{2} \mathrm{O}_{3}\right)$, carbono dissolvido no banho $(\underline{\mathrm{C}})$ e o silício dissolvido o banho ( $\left.\underline{\mathrm{S}}\right)$ tendo como produto desta reação zinco na forma gasosa $\left(\mathrm{Zn}_{(\mathrm{g})}\right)$; ferro que se incorpora ao banho $\left(\mathrm{Fe}_{(1)}\right)$; sílica $\left(\mathrm{SiO}_{2}\right)$ e os gases monóxido e dióxido de carbono. A reação está apresentada pela equação (11).

$$
\begin{aligned}
& (\mathrm{ZnO})+\left(\mathrm{Fe}_{2} \mathrm{O}_{3}\right)+1,5 \underline{\mathrm{C}}+\underline{\mathrm{Si}}=\mathrm{Zn}_{(\mathrm{g})}+2\left(\underline{\mathrm{Fe}}_{(\mathrm{l})}\right)+\left(\mathrm{SiO}_{2}\right)+\mathrm{CO}_{(\mathrm{g})}+0,5 \mathrm{CO}_{2(\mathrm{~g})} \\
& \Delta \mathrm{G}^{\circ}=-142047-104,99 \mathrm{~T} \mathrm{cal} / \mathrm{mol}
\end{aligned}
$$

Em um segundo cenário, o autor não considera a formação de dióxido de carbono. O óxido de zinco $(\mathrm{ZnO})$ combina-se com hematita $\left(\mathrm{Fe}_{2} \mathrm{O}_{3}\right)$, carbono 
dissolvido no banho $(\underline{\mathrm{C}})$ e o silício dissolvido o banho $(\underline{\mathrm{S}})$ tendo como produto desta reação zinco na forma gasosa $\left(\mathrm{Zn}_{(\mathrm{g})}\right)$; ferro que se incorpora ao banho $\left(\mathrm{Fe}_{(\mathrm{I})}\right)$; sílica $\left(\mathrm{SiO}_{2}\right)$ e o gás monóxido de carbono. A reação está apresentada pela equação (12).

$$
\begin{aligned}
& (\mathrm{ZnO})+\left(\mathrm{Fe}_{2} \mathrm{O}_{3}\right)+\underline{\mathrm{C}}+\underline{\mathrm{Si}}=\mathrm{Zn}_{(\mathrm{g})}+2\left(\underline{\mathrm{Fe}_{(\mathrm{l})}}\right)+\left(\mathrm{SiO}_{2}\right)+2 \mathrm{CO}_{(\mathrm{g})} \\
& \Delta \mathrm{G}^{\circ}=-122870-125,16 \mathrm{~T} \mathrm{cal} / \mathrm{mol}
\end{aligned}
$$

No terceiro cenário, o autor considera que a quantidade de silício para a reação de redução é superior à quantidade de carbono para a reação de redução ou que o ferro gusa líquido não tem quantidade de carbono para que haja a redução pelo carbono. A reação proposta ocorre pela combinação de óxido de zinco $(\mathrm{ZnO})$ com hematita $\left(\mathrm{Fe}_{2} \mathrm{O}_{3}\right)$ e o silício dissolvido o banho (i) tendo como produto desta reação zinco na forma gasosa $\left(Z_{(\mathrm{g})}\right)$; ferro que se incorpora ao banho $\left(\mathrm{Fe}_{(\mathrm{I})}\right)$ e sílica $\left(\mathrm{SiO}_{2}\right)$. Nesta reação, o óxido de zinco $(\mathrm{ZnO})$ é reduzido pelo óxido de ferro (FeO). A reação está apresentada pela equação (13).

$$
\begin{aligned}
& (\mathrm{ZnO})+\left(\mathrm{Fe}_{2} \mathrm{O}_{3}\right)+2 \underline{\mathrm{Si}}=\mathrm{Zn}_{(\mathrm{g})}+2\left(\underline{\mathrm{Fe}_{(I)}}\right)+2\left(\mathrm{SiO}_{2}\right) \\
& \Delta \mathrm{G}^{\circ}=-208470-29,84 \mathrm{~T} \mathrm{cal} / \mathrm{mol}
\end{aligned}
$$

A Figura 7 apresenta a energia livre padrão de Gibbs para as reações de redução de óxido de zinco e óxido de ferro da PAE pelo carbono e silício contidos no ferro gusa líquido. 


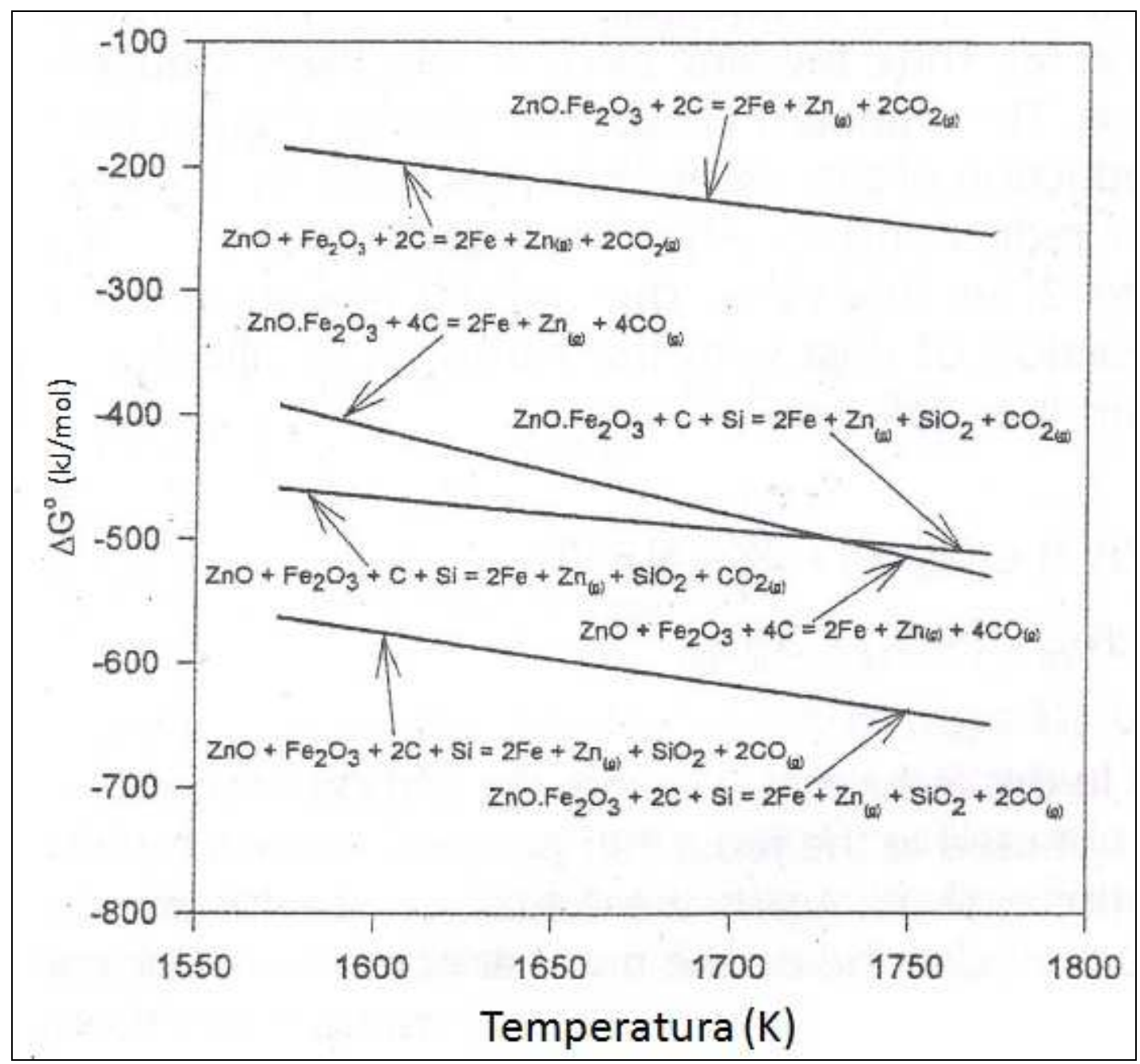

Figura 7. Energia livre padrão de Gibbs para as reações de redução ${ }^{[70]}$.

Observa-se que as reações de redução pelo silício e carbono contidos no ferro gusa líquido apresentam menor valor de energia livre de Gibbs do que a energia das reações onde não há a presença de silício.

Com o objetivo de realizar um estudo cinético da redução carbotérmica da PAE, Morsi e El-Sadek ${ }^{[73]}$, relataram que a reação da PAE com o carbono pode ser expressa da seguinte forma; a Franklinita $\left(\mathrm{ZnFe}_{2} \mathrm{O}_{4}\right)$ reage com 0 carbono tendo como produto o zinco, ferro e o monóxido de carbono. Os referidos autores relatam ainda que esta reação e a combinação das reações de franklinita com carbono tendo como produto óxido de zinco, óxido de ferro e 
monóxido e da reação de óxido de zinco, com óxido de ferro e om carbono tendo como produto zinco, ferro e monóxido de carbono.

Nos experimentos, a perda de peso da carga foi calculada considerando a volatilização do zinco. O zinco volatilizado foi coletado em um condensador refrigerado a água.

Para o cálculo da energía de ativação aparente, a equação $[-\ln (1-\mathrm{x})]=$ kt apresentou o melhor ajuste. De posse do valor de $k$, os referidos autores plotaram o gráfico (In $\mathrm{k} \times 1 / \mathrm{T})$. A equação de Arrhenius foi utilizada para calcular a energía de ativação aparente.

Morsi e El-Sadek ${ }^{[73]}$, encontraram valores de energia de ativação aparente entre 174 e $209 \mathrm{~kJ} / \mathrm{mol}$. Os autores relatam que não há estudos anteriores relatando valores de energia de ativação aparente da redução carbotérmica da PAE além do estudo realizado em 2006 no qual o valor reportado foi de $175 \mathrm{~kJ} / \mathrm{mol}$.

Morsi e El-Sadek ${ }^{[73]}$, realizando experimentos utilizando como catalisador o carbonato de potássio $\left(\mathrm{K}_{2} \mathrm{CO}_{3}\right)$ reportaram valores de energia de ativação aparente da redução carbotérmica da PAE entre 125 e 133kJ/mol. 


\section{OBJETIVOS DA PESQUISA}

Esta pesquisa tem como objetivos:

a) Caracterizar a poeira de aciaria elétrica gerada durante a produção do aço.

b) Estudar o processo de incorporação de massa em ferro gusa final e a volatilização da massa da poeira de aciaria elétrica mediante adição em ferro gusa líquido variando-se:

- a temperatura dos experimentos $\left(1400,1450\right.$ e $\left.1500^{\circ} \mathrm{C}\right)$

- a quantidade de poeira adicionada ao banho de gusa

- o teor de silício do ferro gusa líquido

c) Fazer uma análise cinética da redução do óxido de ferro pelo silício. 


\section{MATERIAIS E MÉTODOS}
A Figura
8 apresenta
o fluxograma
das etapas

desenvolvimento da metodologia desta pesquisa.

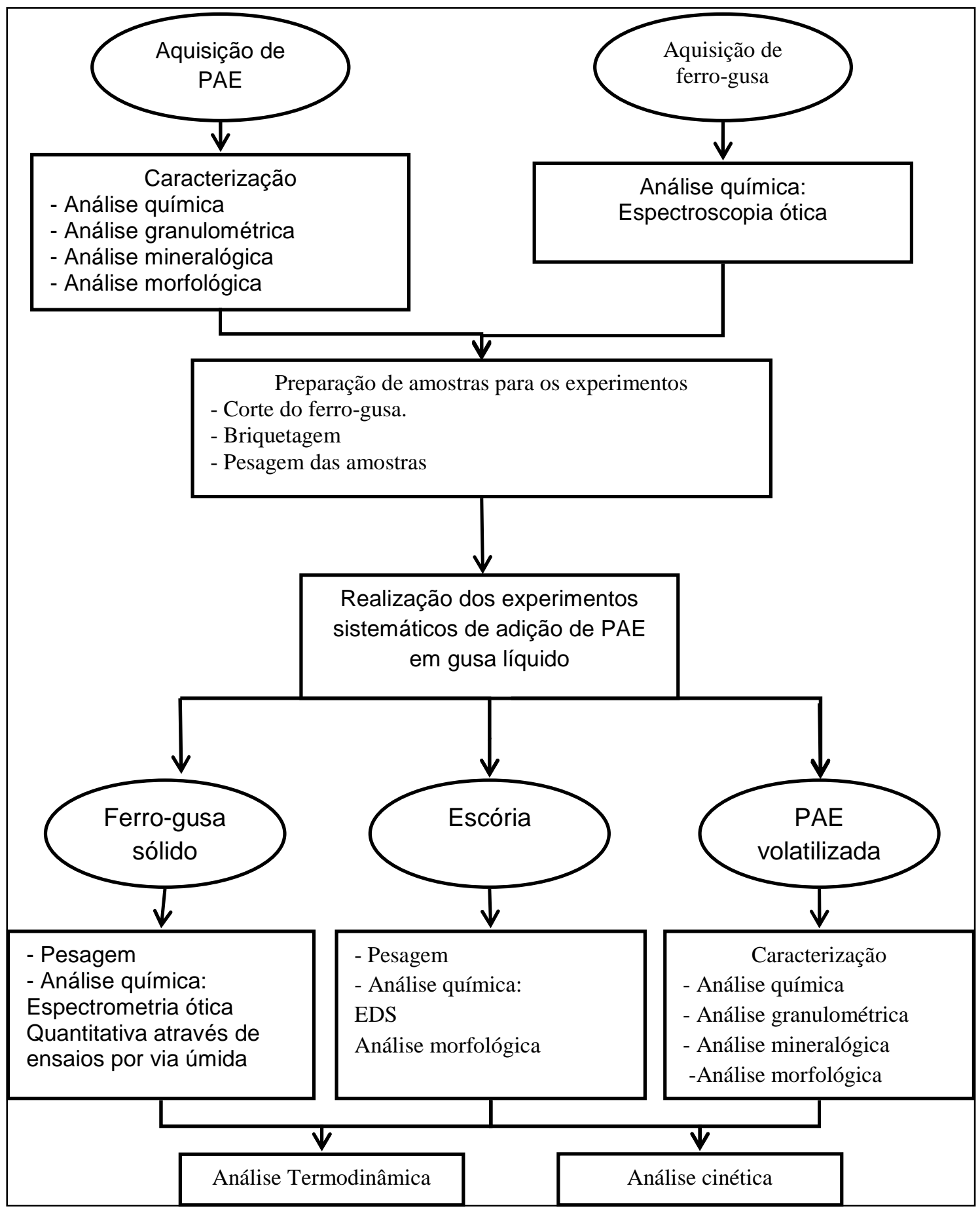

Figura 8. Fluxograma da pesquisa. 


\subsection{MATERIAIS}

Foram utilizadas as seguintes matérias-primas, equipamentos e materiais para a realização dos experimentos:

- Poeira de aciaria elétrica;

- Ferro gusa;

- Cadinhos de Alumina;

- Amostradores a vácuo;

- Forno vertical tubular.

Foram recebidos $100 \mathrm{~kg}$ de PAE em um dispositivo denominado "bag" e $100 \mathrm{~kg}$ de ferro-gusa na forma de lingotes com a massa variando entre 1 e $7 \mathrm{~kg}$, de siderúrgicas situadas na região da grande Vitória, no estado do Espírito Santo.

\subsection{MÉTODOS}

Para a execução deste trabalho, foram desenvolvidas as seguintes etapas:

- Aquisição das matérias-primas;

- Caracterização química, mineralógica e morfológica da PAE;

- Realização dos testes de adição de PAE, sob a forma de briquetes, no banho de ferro gusa, em um forno tubular vertical;

- Caracterização química, mineralógica e morfológica do material restante no cadinho, após os experimentos (ferro gusa e escória) e da PAE volatilizada para avaliar a volatilização de massa de PAE e a incorporação de massa de PAE no banho de ferro gusa. 
De posse das matérias-primas, a etapa seguinte foi o quarteamento da amostra de PAE para obtenção de uma amostra com $600 \mathrm{~g}$ para se proceder a etapa de caracterização química, mineralógica e morfológica da PAE mediante várias técnicas de caracterização, a saber:

- análise química;

- análise granulométrica;

- área de superfície específica;

- caracterização da forma das partículas da poeira mediante o uso de microscopia óptica e eletrônica de varredura;

- análise por dispersão de energia;

- difração de raios-X.

\subsubsection{Análise química}

Os lingotes de ferro-gusa foram cortados utilizando-se uma máquina com disco de corte até obterem-se amostras de gusa com massa entre 300 e $1000 \mathrm{~g}$. Entre as amostras cortadas, foi feito o quarteamento até obter-se uma única amostra, a superfície da amostra que sofreu o corte foi lixada com uma lixa 80 e depois encaminhada para um espectrômetro óptico para a realização da análise química.

A análise química fez-se necessária para se confirmar os teores dos vários elementos presentes na PAE e no ferro gusa. A PAE foi analisada utilizando-se a técnica de espectrometria por fluorescência de raios-X (FRX) e o ferro-gusa inicial e final foram analisados por espectrometria óptica. Amostras de gusa retiradas em tempo pré-estabelecidos foram submetidas à análise química quantitativa utilizando ensaios por via úmida (ver procedimento no 
anexo A) para obtenção do teor de silício e via combustão em aparelho LECO CS-400 para obtenção do teor de carbono e enxofre.

\subsubsection{Análise granulométrica}

$\mathrm{Na}$ análise granulométrica da amostra de PAE foi empregado um analisador de tamanho de partículas (MALVERN 2600-LC), que se baseia no espalhamento de luz causado pelas partículas quando incide sobre as mesmas um feixe de raio laser.

\subsubsection{Difração de raios-X}

A difração de raios-X (DRX) foi utilizada para a determinação dos principais compostos presentes na amostra de PAE. O equipamento utilizado foi um difratômetro de raios-X, modelo MPD 1880. Com o auxílio de um software instalado em um computador, o difratograma resultante da amostra foi comparado com difratogramas de compostos constantes em um banco de dados, desta comparação resultaram os compostos químicos que constituíam a amostra de PAE.

\subsubsection{Análise Microscópica}

As microscopias óptica e eletrônica de varredura foram utilizadas para analisar a morfologia e a estrutura das partículas da PAE. A amostra de PAE foi colada em uma fita de carbono de dupla face sobre um suporte, recoberta com ouro e levada ao MEV para observação. Para fazer uma análise qualitativa e semi-quantitativa dos elementos presentes na PAE, foi realizada uma análise 
por EDS. Esta mesma técnica foi utilizada para analisar as amostras de escória e as amostra de PAE volatilizada.

\subsection{METODOLOGIA ADOTADA PARA ADIÇÃO DE PAE EM FERRO GUSA LÍQUIDO}

O ferro gusa com composição química e quantidades conhecidas $(800,10$ a 825,04 gramas) foi carregado em um cadinho de alumina de alta alumina TIPO 710 composição química; alumina - 99,7\%, sílica - 0,08\%, magnésio $-0,07 \%$ com as dimensões; altura $-110 \mathrm{~mm}$, diâmetro $-64 \mathrm{~mm}$ e fundo $-64 \mathrm{~mm}$, capacidade aproximada de 0,35 litro. Este cadinho foi então levado até um forno vertical tubular, (mostrado na Figura 9) e injetado argônio na câmara de aquecimento, para evitar a oxidação do ferro gusa. Quando o forno atingiu a temperatura de trabalho, a PAE (na forma de briquetes) foi adicionada no forno.

Os dados obtidos nestes experimentos foram utilizados para elaborar 0 balanço de massa e a análise cinética da redução dos óxidos de ferro pelo silício.

Após a adição da PAE, foram retiradas amostras de metal, através de amostradores a vácuo. O tempo de reação passou a ser contato imediatamente após a adição da PAE.

Para retirar a escória parcial dos experimentos foi utilizada uma barra de aço inox, após os 15 minutos de experimento, a barra de inox era imersa na escória, a escória aderia à barra e com o resfriamento rápido em água se desprendia e era coletada para análise. 


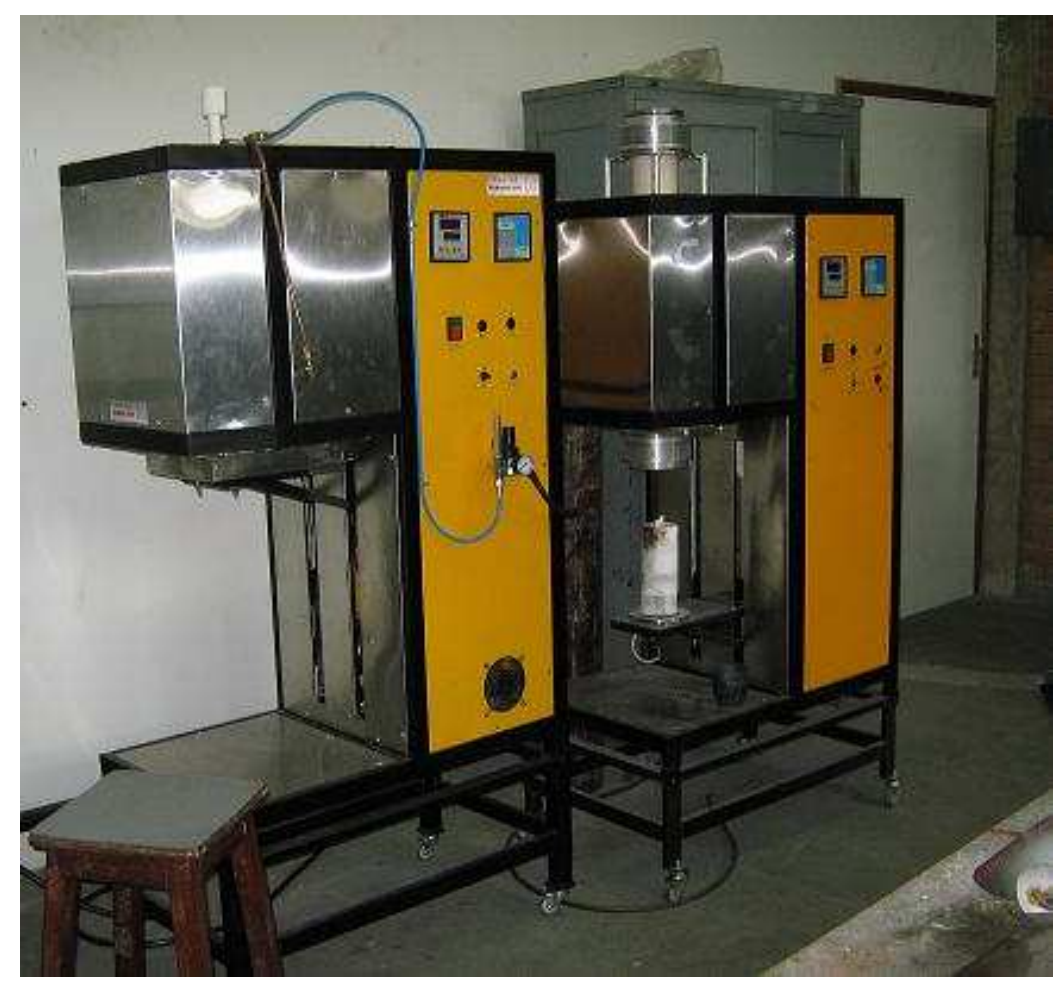

Figura 9. Forno vertical tubular

Cada experimento de adição de PAE no ferro gusa líquido, basicamente, envolveu os seguintes passos:

1) carregamento do cadinho contendo ferro gusa no forno;

2) abertura do sistema de entrada de gás argônio câmara aquecida a uma vazão de 5 litros/minuto, controlado por um rotâmetro. O gás foi injetado pela parte inferior do dispositivo, através de dois canais que conduziram o gás para o interior da zona aquecida.

3) acionamento do forno e do controlador para a realização do experimento a uma taxa de aquecimento de $10^{\circ} \mathrm{C}$ por minuto até a temperatura de $800^{\circ} \mathrm{C}$, manutenção do equipamento nesta temperatura por 10 minutos e $5^{\circ} \mathrm{C}$ por minuto a partir desta temperatura até a temperatura de ensaio e manutenção do equipamento nesta temperatura por 60 minutos. 
4) retirada de uma amostra de ferro gusa líquido na temperatura do experimento utilizando amostrador à vácuo;

5) Adição de PAE no ferro gusa líquido;

6) retirada, em tempos de 1; 3; 5; 7; 10 e 15 minutos após o início do contato entre o ferro gusa e a PAE, de amostras do ferro gusa líquido;

7) retirada em tempos pré-estabelecidos de amostras da escória e da poeira volatilizada;

8) resfriamento do banho à mesma velocidade utilizada para o aquecimento;

9) fechamento do sistema de injeção de gás inerte, após a solidificação do gusa e da escória formada durante o experimento;

10) retirada do cadinho do equipamento;

11) desligamento do forno e do controlador.

De posse dos resultados das amostras coletadas, os mesmos foram comparados com os alcançados na literatura e com a mistura convencional, para se medir a eficácia do processo.

\subsubsection{Descrição do forno elétrico de resistências}

O forno atinge temperatura de trabalho de até $1700^{\circ} \mathrm{C}$, possui resistências de dissiliceto de molibdênio.

O forno está conectado a um controlador de temperatura onde é possível dentre outras funções, programar a temperatura que se desejar atingir, a taxa de aquecimento ( $\left.{ }^{\circ} \mathrm{C} / \mathrm{min}\right)$ e o tempo de permanência na temperatura dos ensaios. O forno trabalha com uma tensão de 208/240 V e freqüência de 50/60 Hz. A potência utilizada pelo forno é de 5000 W. A Figura 10 apresenta o controlador de temperatura do forno. 


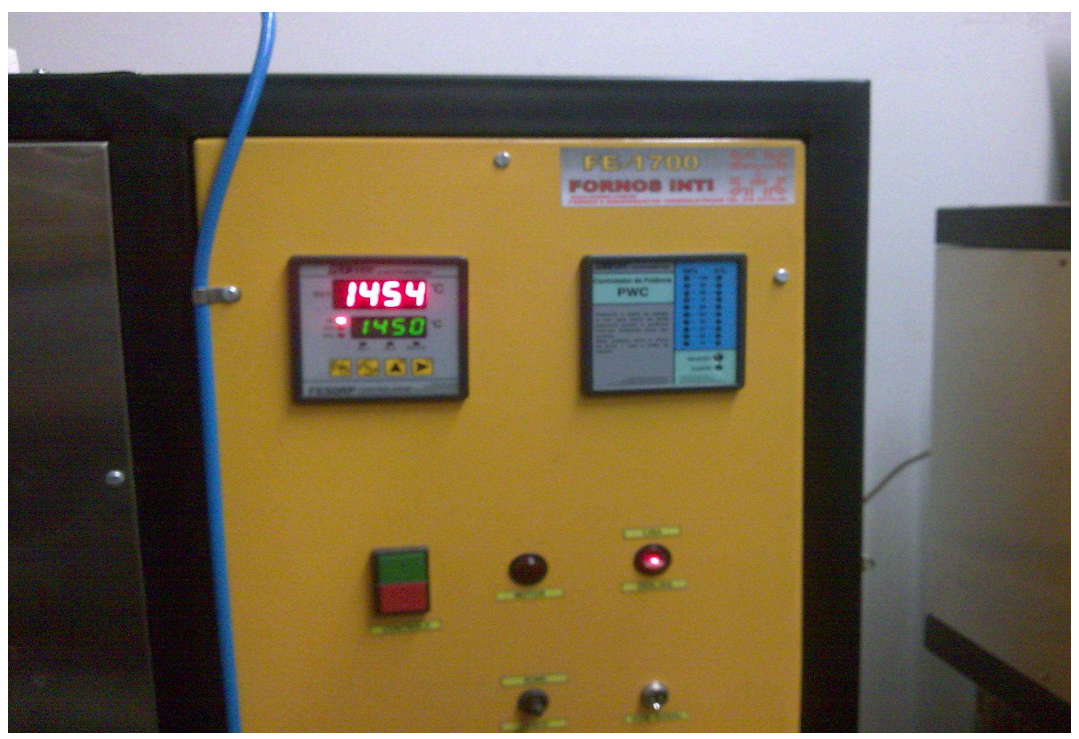

Figura 10. Vista do controlador do forno.

A Figura 11 apresenta o interior da câmara do forno com resistência exposta com capacidade para trabalhar com cadinhos de até 1 litro.

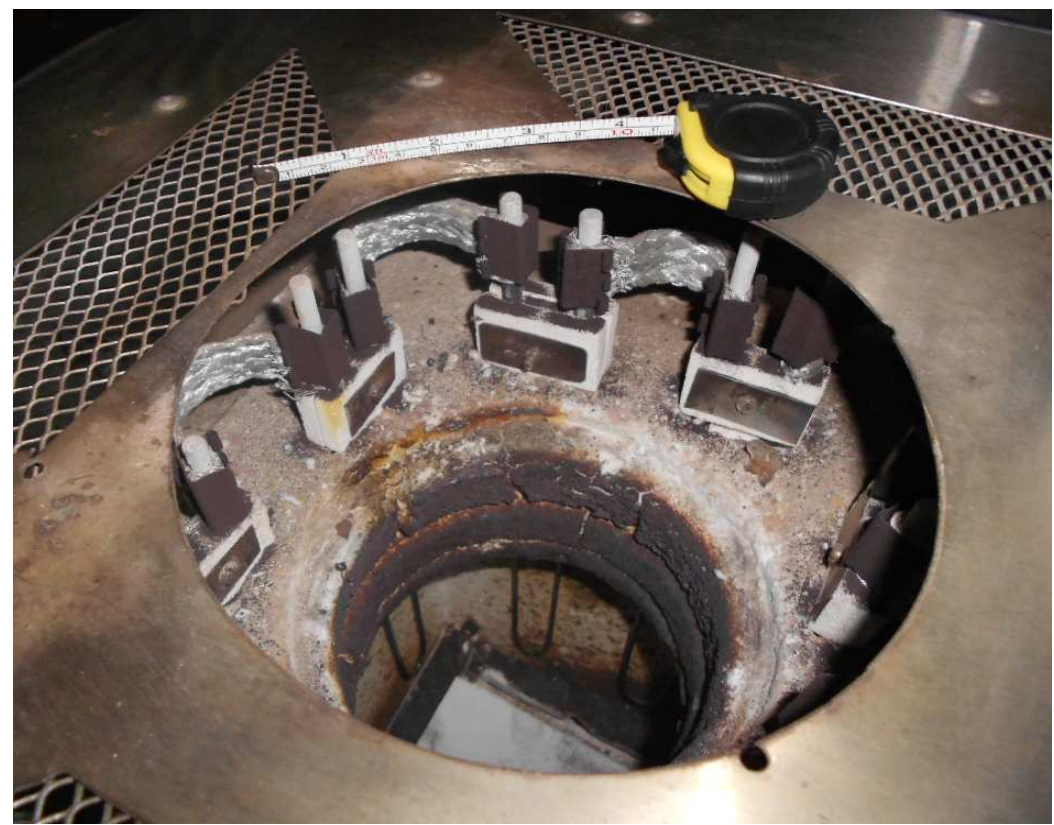

Figura 11. Vista superior da câmara interna com resistência.

\subsubsection{Cálculo de massa dos experimentos e briquetagem da mistura}

No cálculo da massa de PAE a ser adicionada, foi levado em conta a composição química do ferro gusa (\% de silício) e sua massa, além da 
composição química da PAE; considerando a redução completa pelo silício do ferro gusa de todos os óxidos contidos no resíduo, que teoricamente seriam reduzidos pelo silício. Sabendo a massa estequiométrica de PAE, calculou-se $20 \%$ acima do estequiométrico de poeira ou $20 \%$ abaixo do estequiométrico. Assim sendo, Tabela 2 apresenta os ensaios realizados.

Tabela 2. Caracterização dos experimentos realizados.

\begin{tabular}{lccc}
\hline Ensaios & Massa de ferro gusa Inicial & $\begin{array}{c}\text { Massa de PAE } \\
\text { adicionada }\end{array}$ & \% Si Inicial \\
\hline 1400 Hipo A Si & 820,50 & 77,53 & 1,62 \\
1400 Esteq A Si & 805,40 & 95,10 & 1,61 \\
1400 Hiper A Si & 809,60 & 114,70 & 1,85 \\
1400 Hipo M Si & 807,34 & 42,90 & 0,67 \\
1400 Esteq M Si & 822,44 & 54,60 & 0,85 \\
1400 Hiper M Si & 825,04 & 65,70 & 0,54 \\
1400 Esteq B Si & 806,20 & 11,80 & 0,27 \\
1400 Hiper B Si & 800,10 & 14,00 & 0,23 \\
1450 Hipo A Si & 817,00 & 77,12 & 1,40 \\
1450 Esteq A Si & 818,00 & 96,58 & 1,60 \\
1450 Hiper A Si & 811,90 & 115,02 & 1,38 \\
1450 Hipo M Si & 823,84 & 43,80 & 0,61 \\
1450 Esteq M Si & 824,60 & 54,70 & 0,95 \\
1450 Hiper M Si & 821,84 & 65,50 & 0,64 \\
1450 Esteq B Si & 810,60 & 11,83 & 0,34 \\
1450 Hiper B Si & 801,30 & 14,03 & 0,29 \\
1500 Hipo A Si & 815,38 & 61,60 & 1,38 \\
1500 Esteq A Si & 823,87 & 77,70 & 1,57 \\
1500 Hiper A Si & 814,86 & 92,16 & 1,44 \\
1500 Hipo M Si & 810,25 & 41,00 & 0,96 \\
1500 Esteq M Si & 806,85 & 51,00 & 0,93 \\
1500 Hiper M Si & 810,75 & 63,00 & 1,14 \\
1500 Esteq B Si & 815,40 & 18,00 & 0,36 \\
1500 Hiper B Si & 810,20 & 22,50 & 0,28 \\
\hline
\end{tabular}

Em relação à primeira coluna da Tabela 2, os 4 primeiros números representam a temperatura dos ensaios. As abreviações (Esteq, Hipo e Hiper) representam a massa de poeira adicionada, sendo (Esteq) massa estequiométrica, (Hipo) 20\% abaixo do estequiométrico e (Hiper) $20 \%$ acima do Estequiométrico. As três ultimas letras identificam o teores de silício, sendo (A Si) para teores variando de 1,38 a 1,85\%, (M Si) para os teores entre 0,54 e $1,14 \%$ e (B Si) teores variando de 0,23 a $0,36 \%$. 
Para a fabricação dos briquetes, utilizou-se uma prensa hidráulica manual. Os briquetes foram prensados em uma pressão de 14,5 MPa durante um tempo de 20 segundos em uma matriz de aço com PAE na forma como recebido, após este tempo reduziu-se a pressão da prensa sobre o molde e em seguida retirou-se o briquete do mesmo. Os briquetes utilizados possuíam diâmetro de 25,4mm e altura entre 10 e $25 \mathrm{~mm}$. Em todos os experimentos a PAE utilizada foi previamente colocada durante 24 horas em estufa à temperatura de $115^{\circ} \mathrm{C}$ para perda da umidade.

A matriz de aço possui $25,4 \mathrm{~mm}$ de diâmetro interno e 45 de diâmetro externo. A Figura 12 apresenta a matriz utilizada para os ensaios.

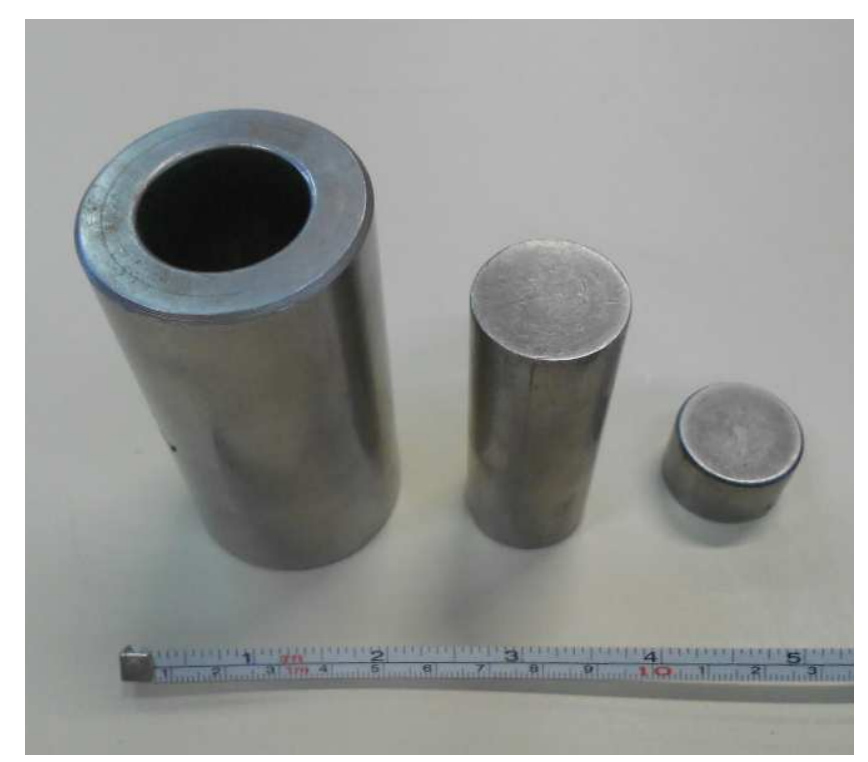

Figura 12. Matriz dos briquetes.

\subsubsection{Captação de emissões e material volátil}

Foram realizadas coletas de amostras da poeira produzida pelo processo de redução com o objetivo de avaliar a volatilização da PAE através do aparato experimental. 
Um dispositivo experimental foi montado para o estudo da evaporação da PAE. Este dispositivo denominado coletor da poeira volatilizada foi posicionado sobre o forno tubular vertical.

Durante os experimentos, o gás proveniente do forno, era direcionado para o dispositivo, objetivando coletar os materiais particulados.

A PAE foi adicionada ao ferro gusa líquido à temperatura de trabalho pré-estabelecida para que ocorresse a volatilização parcial da mesma. Após o resfriamento, foi realizada a coleta para análise química da amostra retida no coletor de PAE volatilizada.

As técnicas utilizadas na caracterização dos produtos obtidos nos experimentos de avaliação da volatilização da PAE foram as seguintes:

- análise química,

- microscopia eletrônica de varredura (MEV) e análise semi-quantitativa de microrregiões por espectrosopia de energia dispersiva (EDS),

- difração de raios-X.

\subsection{ANÁLISE CINÉTICA DA REDUÇÃO DO ÓXIDO DE FERRO}

Foi realizado um estudo cinético do processo de redução silicotérmica dos óxidos de ferro da PAE sob a forma de briquete adicionada em ferro gusa líquido.

O cálculo das constantes cinéticas de velocidade foi realizado utilizando os valores das frações de reação em um modelo de reação de primeira ordem. Este modelo de reação de $1^{\underline{a}}$ ordem foi 0 escolhido porque a reação entre 
óxidos e redutor acontece simultaneamente em vários pontos do banho de ferro gusa.

A equação cinética, equação $(14)^{[73]}$, considera a velocidade proporcional à fração não reagida e a ordem de reação um.

$\ln (1-f r)=-k t$

Onde:

fr. fração de reação

k: constante de velocidade de reação em uma dada temperatura (1/min)

$t$ tempo (minutos)

A fração de reação dos óxidos foi calculada tomando-se como base os resultados da análise química do teor de silício das amostras de ferro gusa.

Calculados os valores das constantes cinéticas de velocidade, utilizou-se a equação (15) ${ }^{[73]}$, equação de Arrhenius, para encontrar as energias de ativação aparente para cada conjunto de experimentos.

$$
k=k_{o} e^{[-E A / R T]}
$$

Onde:

$k$ : constante de velocidade de reação em uma dada temperatura $\left(\min ^{-1}\right)$

$k_{0}$ : fator de frequência

$E A$ : energia de ativação aparente $(\mathrm{J} / \mathrm{Mol})$

$R$ : constante universal dos gases $\left(\mathrm{J} / \mathrm{Mol}^{*} \mathrm{~K}\right)$

$\mathrm{T}$ : temperatura $(\mathrm{K})$

\subsection{ANÁLISE TERMODINÂMICA}

Foi realizada uma avaliação termodinâmica com o objetivo de conhecer a composição de equilíbrio das escórias e do ferro gusa. Para isso, utilizou-se o 
programa THERMOCALC e o FACTSAGE 6.3. O primeiro pertence ao Instituto Federal do Espírito Santo - IFES e o segundo a Universidade de São Paulo USP. Com esses programas foi possível conhecer as atividades de todos os óxidos presentes na escória e no ferro gusa, fases e temperatura de fusão de um conjunto de experimentos. 


\section{RESULTADOS E DISCUSSÃo}

\subsection{CARACTERIZAÇÃO DA POEIRA DE ACIARIA ELÉTRICA}

\subsubsection{Análise Química}

O resultado da análise química da PAE na forma "como recebido" é apresentado na Tabela 3.

Tabela 3. Composição química elementar da PAE na forma "como recebido" por FRX.

\begin{tabular}{|c|c|}
\hline Elemento & Composição (\%) \\
\hline $\mathrm{Fe}_{\text {total }^{*}}$ & 38,90 \\
\hline$\left.\mathrm{Zn}_{\text {total }}\right|^{* *}$ & 11,70 \\
\hline $\mathrm{Ca}$ & 3,06 \\
\hline $\mathrm{Si}$ & 1,66 \\
\hline $\mathrm{Mn}$ & 2,27 \\
\hline $\mathrm{Mg}$ & 1,33 \\
\hline $\mathrm{Cl}$ & 4,64 \\
\hline $\mathrm{K}$ & 1,87 \\
\hline $\mathrm{Pb}$ & 1,48 \\
\hline S & 0,88 \\
\hline $\mathrm{Al}$ & 0,32 \\
\hline $\mathrm{P}$ & 0,14 \\
\hline $\mathrm{Cu}$ & 0,28 \\
\hline $\mathrm{Cr}$ & 0,21 \\
\hline $\mathrm{Ti}$ & 0,08 \\
\hline $\mathrm{Br}$ & 0,13 \\
\hline Sn & 0,07 \\
\hline $\mathrm{Cd}$ & 0,03 \\
\hline
\end{tabular}

Pode-se observar que o teor de Fe e o teor de Zn são compatíveis com os teores de ferro $(24,9$ a $46,9 \%)$ e de zinco $(11,12$ a $26,9 \%)$ relatados por Nyrenda ${ }^{[74]}$ para as siderúrgicas americanas.

De acordo com a ABNT NBR 1004:2004 ${ }^{[75]}$, no Anexo B, fonte geradora: ferro e aço e o código de identificação: K061, a PAE devido à presença de cádmio e chumbo é considerada um resíduo perigoso, classe I, de fonte específica. 
O ferro gusa recebido de duas diferentes siderúrgicas, após a análise quantitativa por espectrometria de emissão óptica foi classificado em gusa com alto teor de silício (com teor de Si de 1,78\%, teor de C de 4,60\%, Mn de $0,0810 \%, P$ de $0,0213 \%$, S inferior a 0,0050 e teor de ferro de $92,1 \%$ ) e gusa com baixo teor de silício (com teor de Si de 0,22\%, C de 4,30\%, Mn de 0,097\%, $P$ de $0,0049 \%$, e $S$ de $0,0064 \%)$.

\subsubsection{Análise granulométrica}

O resultado da análise granulométrica está representado na Figura 13.

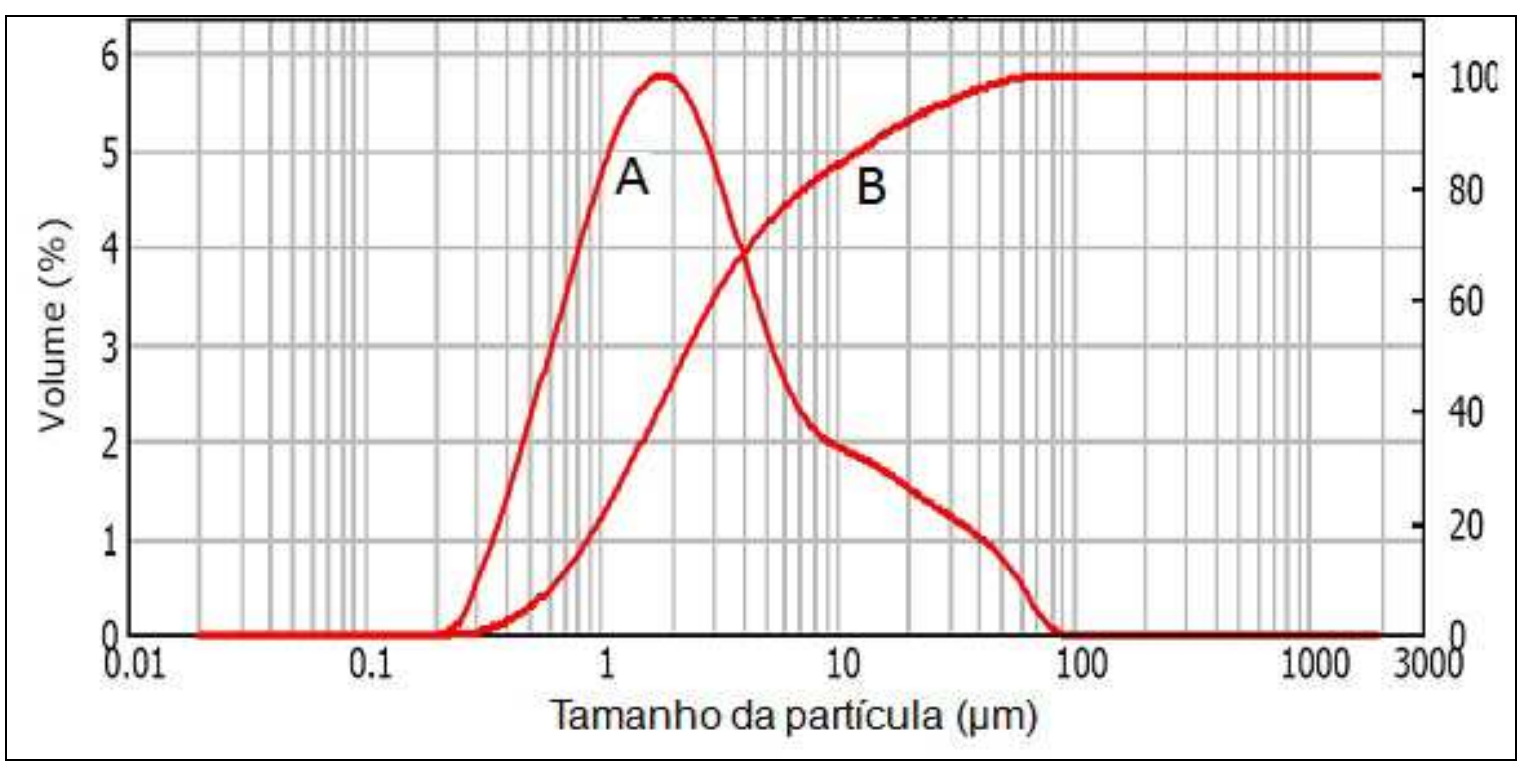

Figura 13. Distribuição do tamanho das partículas da PAE na forma "como recebido".

A linha (A) representa a porcentagem de distribuição do tamanho das partículas, a linha $(B)$ representa a porcentagem acumulada.

A tabela expedida pelo equipamento relata que $10 \%$ da amostra possui diâmetro da partícula menor que $0,672 \mu \mathrm{m}$, e $90 \%$ do material apresenta

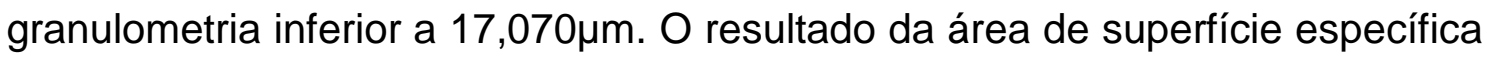
das partículas, medida pelo $\mathrm{BET}$, foi de $3,81 \mathrm{~m}^{2} / \mathrm{g}$ e o diâmetro médio da partícula 2,281 $\mu \mathrm{m}$. 
Telles, Oliveira, Espinosa e Tenório ${ }^{[76]}$, ao realizarem a caracterização da PAE, a análise granulométrica da poeira apresentou que $90,76 \%$ do material possui granulometria inferior a $9 \mu \mathrm{m}$.

Pureza $^{[35]}$, em seu estudo encontrou a área de superfície específica da $\mathrm{PAE}$, medida pelo método $\mathrm{BET}$, um valor igual a $4,72 \mathrm{~m}^{2} / \mathrm{g}$. Este valor está próximo ao encontrado neste trabalho.

\subsubsection{Difração de raios-X}

A Figura 14 apresenta o espectro de difração e as respectivas fases encontradas na amostra do resíduo.

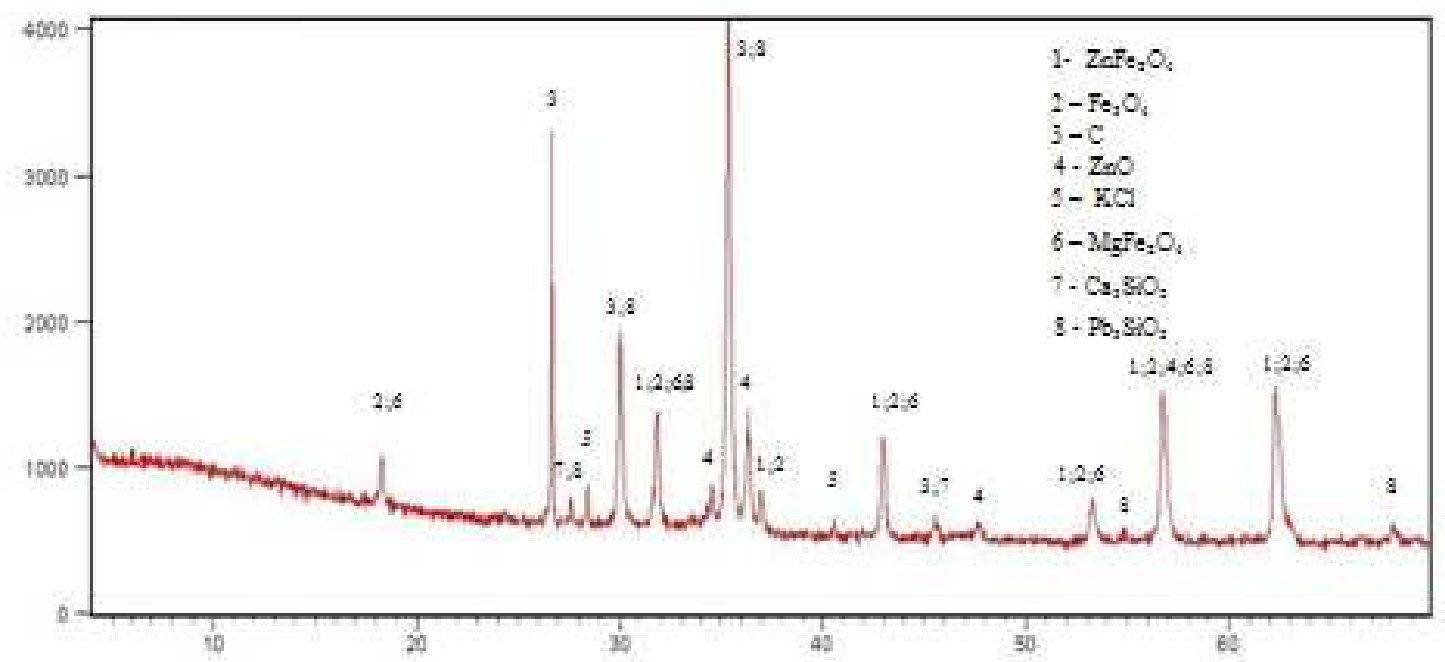

Figura 14. Espectro de difração de raios-X da amostra da PAE e a identificação dos picos.

Observa-se na Figura 14 a predominância da Magnetita $\left(\mathrm{Fe}_{3} \mathrm{O}_{4}\right)$, Magnesioferrita $\left(\mathrm{MgFe}_{2} \mathrm{O}_{4}\right)$ e Franklinita $\left(\mathrm{ZnFe}_{2} \mathrm{O}_{4}\right)$. Apresenta ainda as fases carbono $(\mathrm{C})$, óxido de zinco $(\mathrm{ZnO})$, silvita $(\mathrm{KCl})$, silicato de cálcio $\left(\mathrm{Ca}_{3} \mathrm{SiO}_{5}\right)$ e silicato de chumbo $\left(\mathrm{Pb}_{3} \mathrm{SiO}_{5}\right)$. 
De acordo com outros autores ${ }^{[77,78,79]}$ a magnetita $\left(\mathrm{Fe}_{3} \mathrm{O}_{4}\right)$ e a franklinita $\left(\mathrm{ZnFe}_{2} \mathrm{O}_{4}\right)$ também são os elementos que frequentemente são encontrados na poeira de aciaria elétrica.

\subsubsection{Microscopia eletrônica de varredura e análise de micro-regiões por EDS.}

A Figura 15 apresenta a imagem de partículas de PAE obtidas em MEV onde a região 1 (região da esfera) e a região 2 (região mais clara) foram selecionadas para análise semi-quantitativa e pontual por EDS.
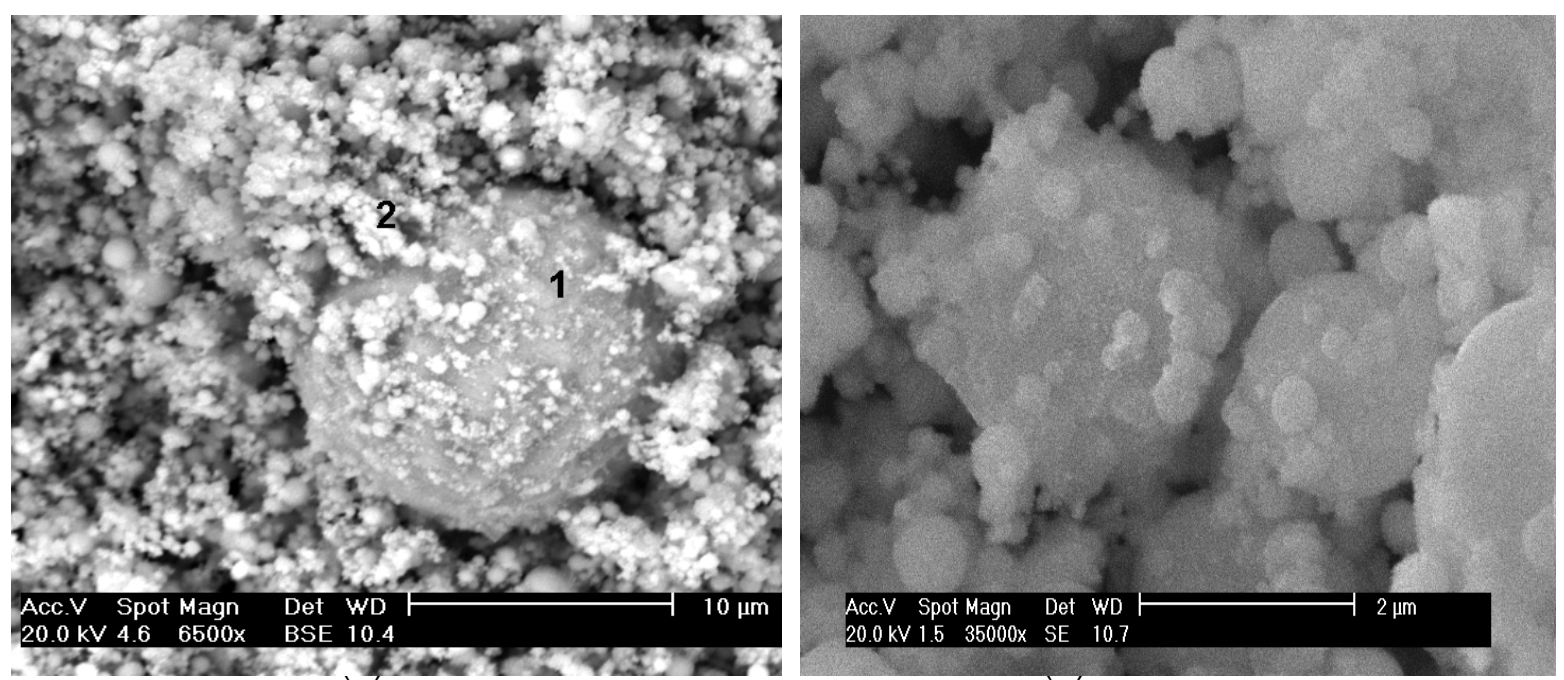

Figura 15. (A) Imagem de elétrons retro-espalhados das partículas de PAE, (B) Imagem de elétrons secundários da região 2 com maior aumento.

Verifica-se na Figura 15 que a PAE "como recebido" é constituída predominantemente de partículas de formato esférico, formato este descrito por diversos autores ${ }^{[12,80,81]}$ e que está diretamente relacionado com o mecanismo de formação das poeiras. Segundo Steven e William ${ }^{[82]}$ a morfologia esférica confirma que o mecanismo de formação da poeira é o de ejeção de escória e metal por bolhas de CO que estouram na superfície o banho. 
A Figura 16 apresenta o espectro de EDS da região 1 (região da esfera).

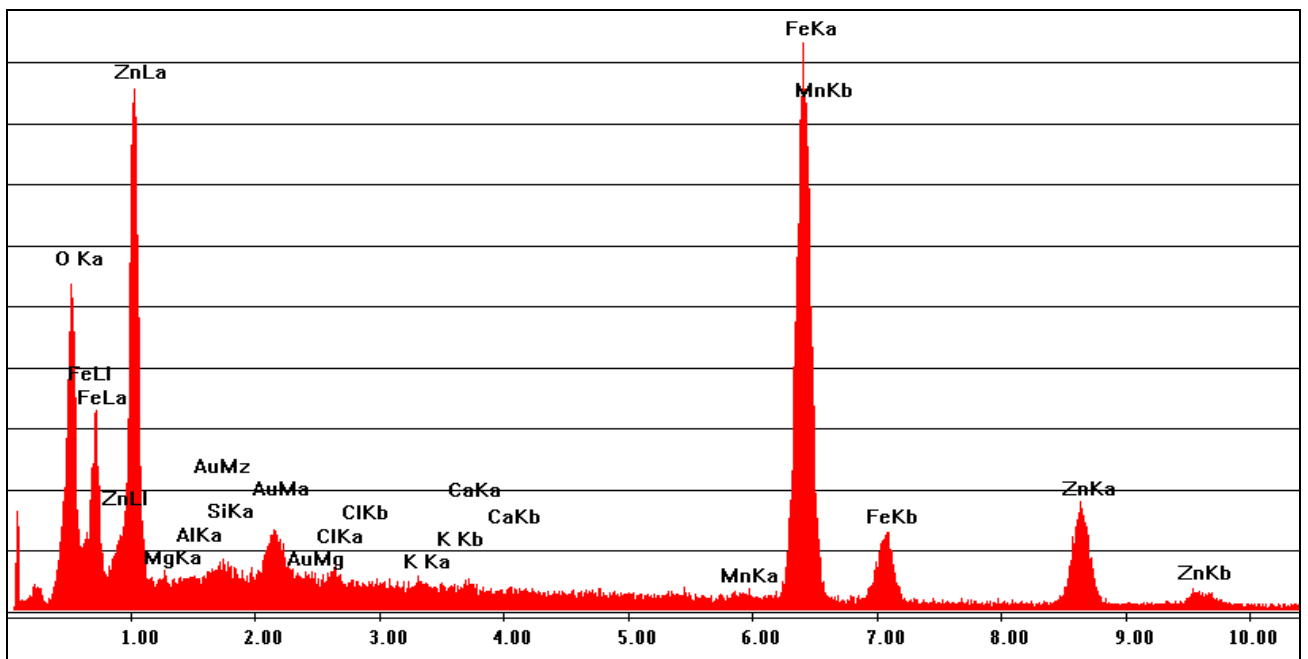

Figura 16. Espectro de EDS correspondente à região 1 (região da esfera).

Observa-se na Figura 16 que ocorre a predominância dos elementos químicos ferro e zinco. A análise semi-quantitativa e pontual desta região teve como resultado $57,40 \%$ de ferro e $25,37 \%$ de zinco.

A Figura 17 apresenta o espectro por EDS correspondente à região 2 (região clara).

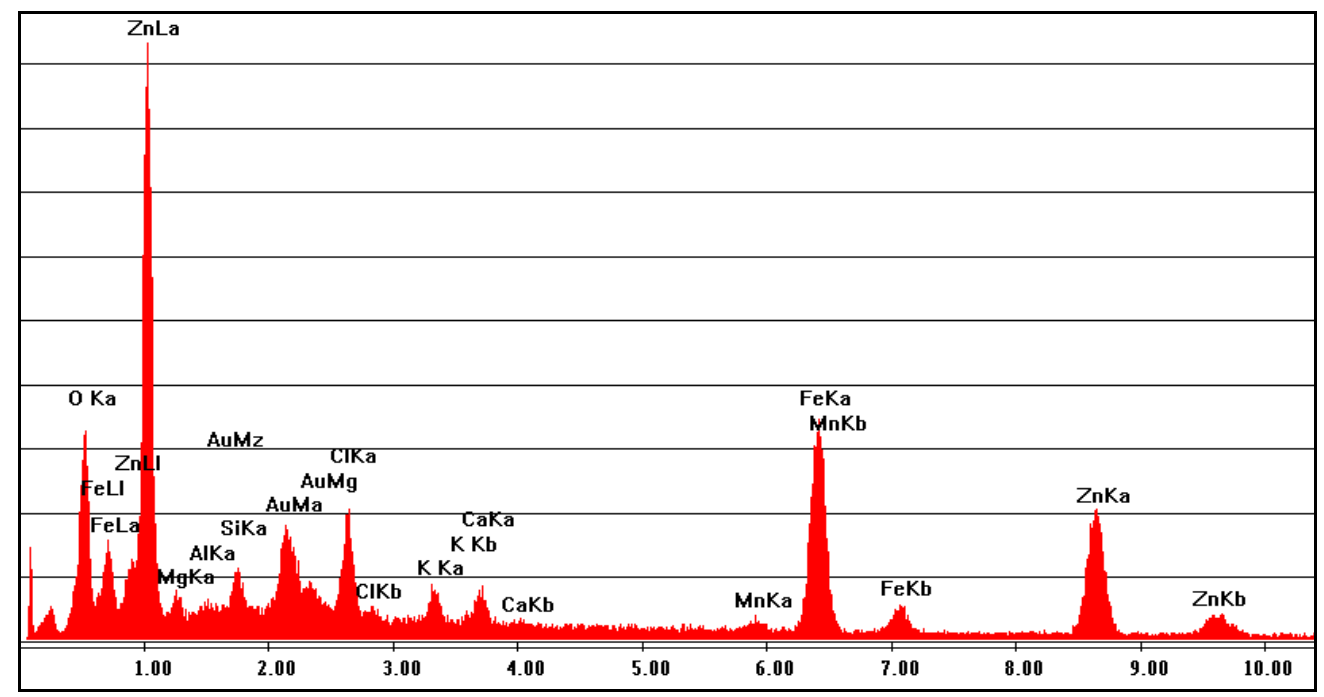

Figura 17. Espectro de EDS da região 2 (região clara). 
Observa-se na Figura 17 que ocorre maior predominância do elemento químico zinco. A análise semi-quantitativa e pontual desta região teve como resultado $29,09 \%$ de ferro e $40,91 \%$ de zinco.

\subsection{EXPERIMENTOS DE ADIÇÃO DE PAE EM FERRO GUSA LÍQUIDO}

Neste item, estão apresentados e discutidos os resultados referentes à parte termodinâmica. A Tabela 4 apresenta os resultados dos teores de silício encontrados nos experimentos.

Tabela 4. Variação da porcentagem de silício do banho em função do tempo.

\begin{tabular}{lccccccc}
\hline \multicolumn{1}{c}{ Ensaios } & \multicolumn{7}{c}{ Tempo (min) } \\
\cline { 2 - 7 } & $\mathbf{T}(\mathbf{0})$ & $\mathbf{1}$ & $\mathbf{3}$ & $\mathbf{5}$ & $\mathbf{7}$ & $\mathbf{1 0}$ & $\mathbf{1 5}$ \\
\hline 1400 Hipo A Si & 1,62 & 1,46 & 1,40 & 1,37 & 1,37 & 1,18 & 0,57 \\
1400 Esteq A Si & 1,61 & 1,32 & 0,80 & 0,51 & 0,38 & 0,27 & 0,23 \\
1400 Hiper A Si & 1,85 & 1,75 & 0,60 & 1,09 & 1,07 & 0,94 & 0,90 \\
1400 Hipo M Si & 0,67 & 0,25 & 0,20 & 0,11 & 0,07 & 0,07 & 0,11 \\
1400 Esteq M Si & 0,85 & 0,31 & 0,11 & 0,15 & 0,13 & 0,11 & 0,07 \\
1400 Hiper M Si & 0,54 & 0,47 & 0,28 & 0,14 & 0,14 & 0,04 & 0,07 \\
1400 Esteq B Si & 0,27 & 0,25 & 0,12 & 0,11 & 0,18 & 0,14 & 0,16 \\
1400 Hiper B Si & 0,23 & 0,19 & 0,09 & 0,08 & 0,07 & 0,05 & 0,06 \\
1450 Hipo A Si & 1,40 & 1,36 & 0,79 & 0,63 & 0,93 & 0,66 & 0,65 \\
1450 Esteq A Si & 1,60 & 1,02 & 0,46 & 0,34 & 0,24 & 0,15 & 0,41 \\
1450 Hiper A Si & 1,38 & 0,98 & 0,46 & 0,33 & 0,30 & 0,36 & 0,26 \\
1450 Hipo M Si & 0,41 & 0,30 & 0,20 & 0,19 & 0,13 & 0,17 & 0,11 \\
1450 Esteq M Si & 0,95 & 0,31 & 0,15 & 0,29 & 0,28 & 0,18 & 0,29 \\
1450 Hiper M Si & 0,64 & 0,37 & 0,22 & 0,14 & 0,05 & 0,10 & 0,15 \\
1450 Esteq B Si & 0,34 & 0,06 & 0,15 & 0,17 & 0,18 & 0,15 & 0,14 \\
1450 Hiper B Si & 0,29 & 0,23 & 0,20 & 0,15 & 0,15 & 0,16 & 0,18 \\
1500 Esteq A Si & 1,38 & 1,06 & 0,49 & 0,37 & 0,13 & 0,29 & 0,47 \\
1500 Hiper A Si & 1,57 & 1,21 & 0,48 & 0,48 & 0,17 & 0,44 & 0,39 \\
1500 Hipo A Si & 1,44 & 1,09 & 1,12 & 0,41 & 0,30 & 0,39 & 0,41 \\
1500 Esteq M Si & 0,96 & 0,65 & 0,40 & 0,37 & 0,32 & 0,33 & 0,37 \\
1500 Hiper M Si & 0,93 & 0,48 & 0,06 & 0,07 & 0,37 & 0,26 & 0,06 \\
1500 Hipo M Si & 1,14 & 0,67 & 0,59 & 0,55 & 0,48 & 0,38 & 0,34 \\
1500 Esteq B Si & 0,36 & 0,21 & 0,10 & 0,11 & 0,09 & 0,08 & 0,07 \\
1500 Hiper B Si & 0,28 & 0,16 & 0,10 & 0,04 & 0,05 & 0,02 & 0,02 \\
\hline
\end{tabular}

Com os dados obtidos na Tabela 4 foi possível traçar curvas de variação do teor de silício do ferro gusa em função do tempo. Esta relação está apresentada nas Figuras 18 e 19. 


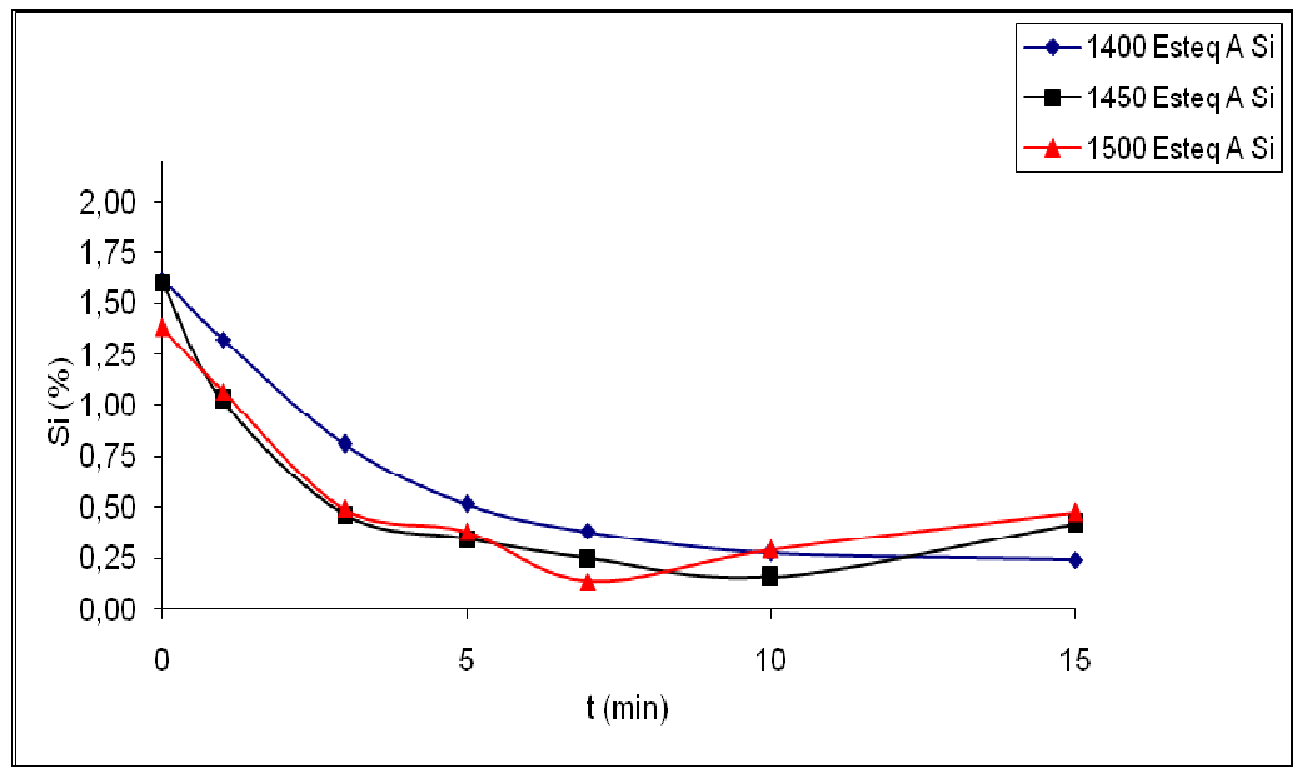

Figura 18. Variação do teor de silício (Esteq A Si) em função do tempo.

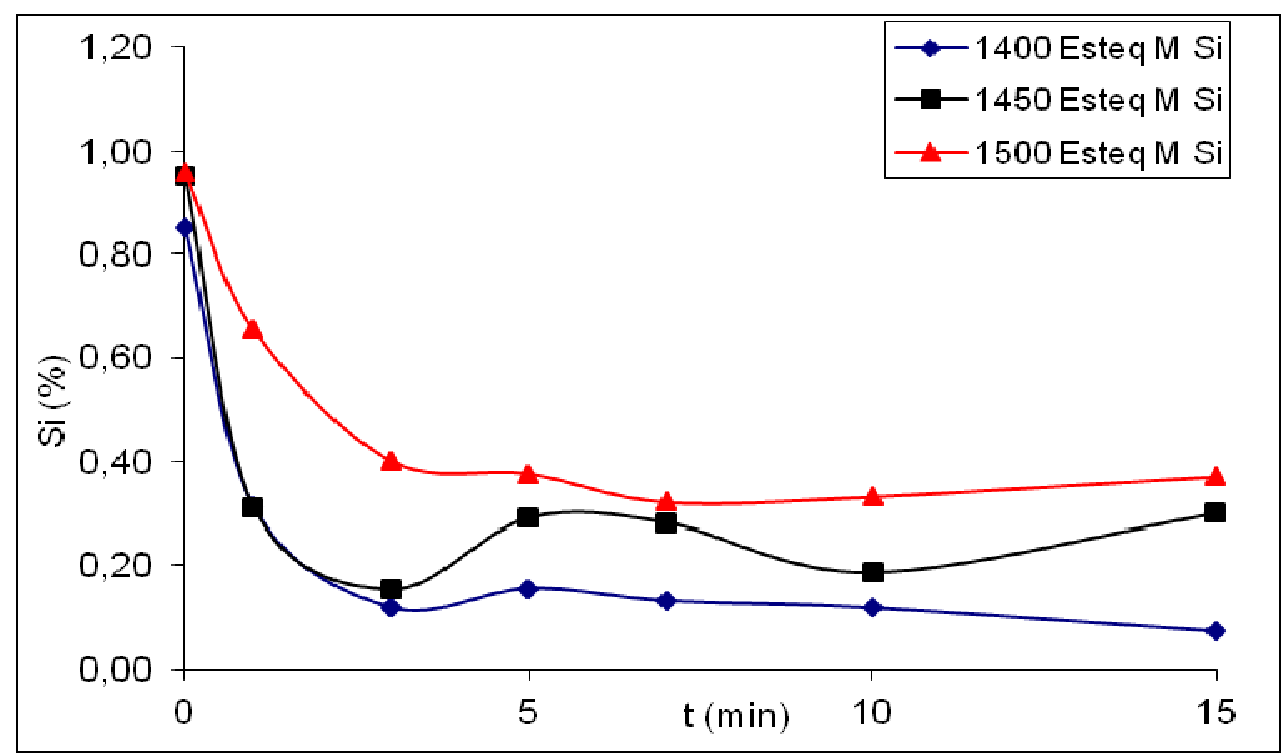

Figura 19. Variação do teor de silício (Esteq M Si) em função do tempo.

Observa-se que ocorre uma redução do teor de silício do ferro gusa nos primeiros 5 minutos, este comportamento foi observado por Oliveira ${ }^{[83]}$ e Grillo ${ }^{[81]}$.

Analisando as Figuras 18 e 19 observa-se também que na temperatura de $1500{ }^{\circ} \mathrm{C}$ e nos tempos de 15 minutos o decréscimo d o teor de silício do ferro gusa foi menor do que para os experimentos nas temperaturas de $1400 \mathrm{e}$ 
$1450^{\circ} \mathrm{C}$. Visando compreender estes resultados foi ge rada a Figura 20 através de simulação computacional.

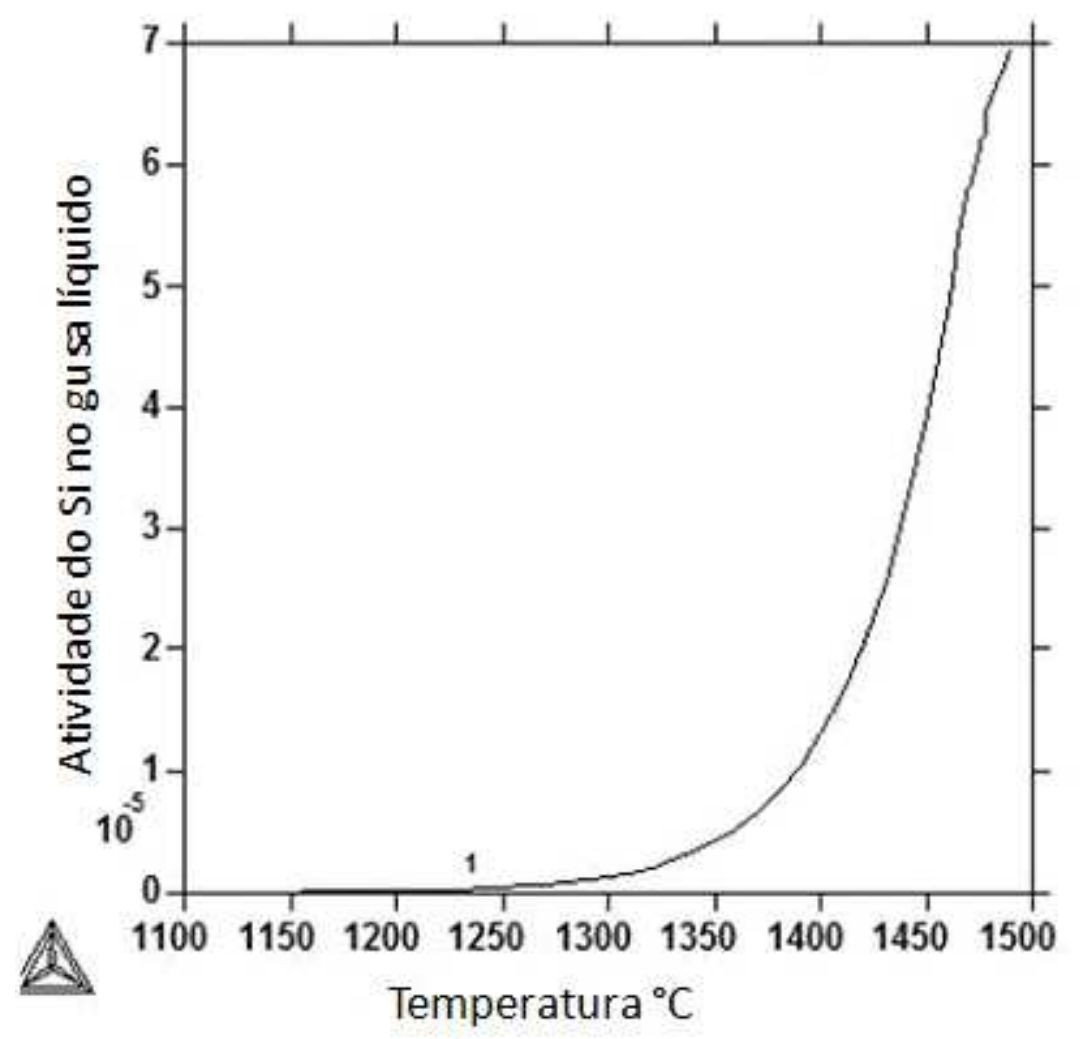

Figura 20. Simulação do teor de silício de equilíbrio no ferro líquido.

Observa-se que nesta simulação, o comportamento do silício de equilíbrio é similar ao observado nos experimentos, ou seja, o aumento da temperatura não favorece o decréscimo do teor de silício do ferro gusa. Pickles $^{[88]}$ também verificou este comportamento.

Analisando o comportamento do teor de silício do ferro gusa nas demais classes de experimentos, verificam-se oscilações no teor de silício no resultado das amostras de ferro gusa. Para realizar uma análise minuciosa faz-se necessário a realização de cálculos termodinâmicos.

Inicialmente ocorre decréscimo do teor de silício do ferro gusa de acordo com as seguintes equações ${ }^{[84,85,86,87]}$ : 
$2(\mathrm{FeO})+\underline{\mathrm{Si}}=2 \mathrm{Fe}_{(l)}+\mathrm{SiO}_{2}$

$\Delta \mathrm{G}^{\circ}=-78570+26,56 \mathrm{~T} \mathrm{cal} / \mathrm{mol}$

e

$(\mathrm{FeO})+\underline{\mathrm{C}}=\mathrm{Fe}_{(\mathrm{l})}+\mathrm{CO}$

$\Delta \mathrm{G}^{\circ}=21320-20,66 \mathrm{~T} \mathrm{cal} / \mathrm{mol}$

Após 5 minutos, com o aumento da atividade da sílica $\left(\mathrm{SiO}_{2}\right)$ na escória, começa a redução do $\mathrm{SiO}_{2}$ pelo carbono ou ferro líquido do banho, de acordo com as seguintes equações:

$\left(\mathrm{SiO}_{2}\right)+2 \underline{\mathrm{C}}=\mathrm{Si}+2 \mathrm{CO}$

$\Delta \mathrm{G}^{\circ}=138900-95,72 \mathrm{~T} \mathrm{cal} / \mathrm{mol}$

e

$\left(\mathrm{SiO}_{2}\right)+2 \underline{\mathrm{Fe}}=2(\mathrm{FeO})+\underline{\mathrm{Si}}$

$\Delta \mathrm{G}^{\circ}=85560-34,2 \mathrm{~T} \mathrm{cal} / \mathrm{mol}$

A Figura 21 apresenta a energia livre de Gibbs das equações 1 e $3^{[88]}$. 


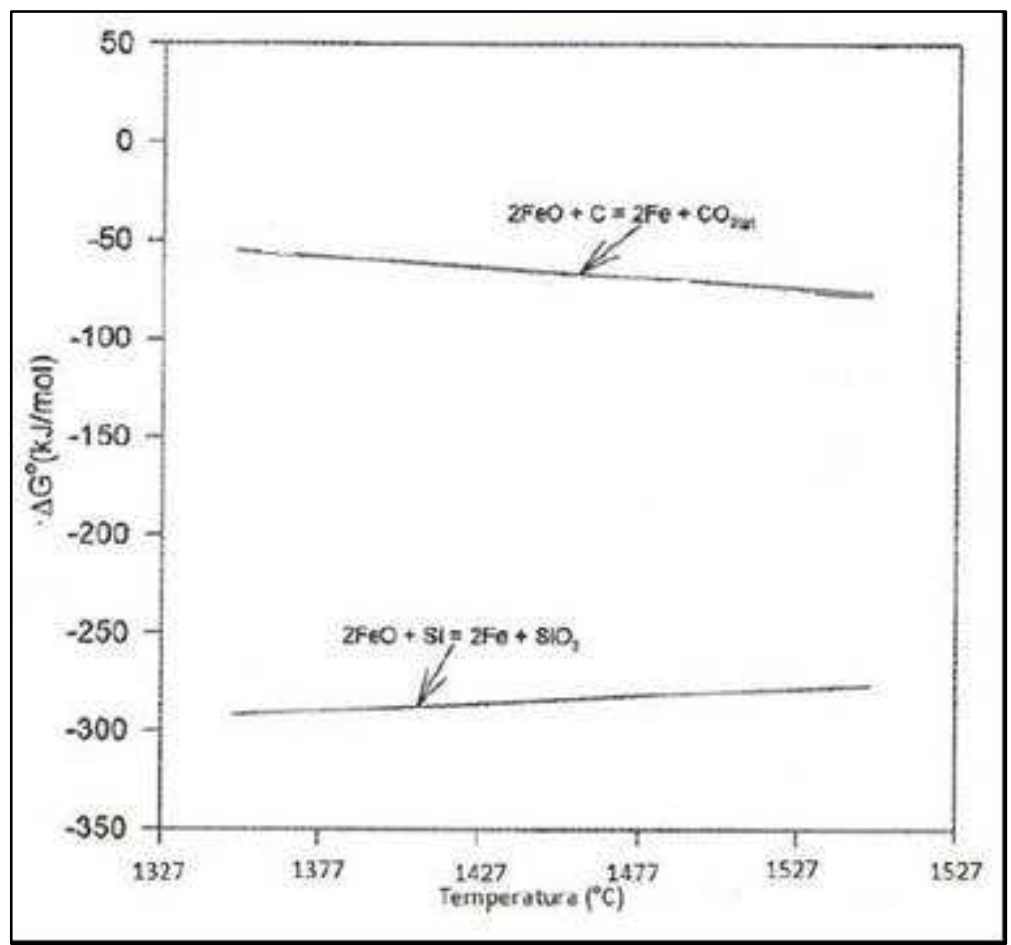

Figura 21. Energia livre das reações de redução do $\mathrm{FeO}^{(87)}$.

Pela análise da Figura 21, nota-se que a reação de redução do FeO pelo silício apresenta maior potencial termodinâmico para ocorrer do que a de redução do $\mathrm{FeO}$ pelo carbono.

Visando verificar quais as reações que possuem potencial de ocorrer no instante (15 minutos) e as oscilações do silício no ferro gusa, foi realizado cálculos da energia livre de Gibbs $(\Delta \mathrm{G})$. Para isso utilizou-se o programa computacional termodinâmico Factsage para o cálculo das atividades dos óxidos na escória. A Tabela 5 apresenta as atividades dos principais óxidos na escória calculados pelo programa computacional Factsage 6.3. 
Tabela 5. Atividade do $\mathrm{SiO}_{2}$ e FeO nas escórias finais.

\begin{tabular}{ccc}
\hline Ensaios & $\mathrm{SiO}_{2}$ & FeO \\
\hline 1400 Hipo A Si & 0,63 & 0,10 \\
1400 Esteq A Si & 0,78 & 0,02 \\
1400 Hiper A Si & 0,59 & 0,08 \\
1400 Hipo M Si & 0,50 & 0,16 \\
1400 Esteq M Si & 0,34 & 0,22 \\
1400 Hiper M Si & 0,51 & 0,14 \\
1400 Esteq B Si & 0,84 & 0,03 \\
1400 Hiper B Si & 0,62 & 0,22 \\
1450 Hipo A Si & 0,61 & 0,13 \\
1450 Esteq A Si & 0,74 & 0,08 \\
1450 Hiper A Si & 0,74 & 0,09 \\
1450 Hipo M Si & 0,71 & 0,10 \\
1450 Esteq M Si & 0,64 & 0,11 \\
1450 Hiper M Si & 0,45 & 0,15 \\
1450 Esteq B Si & 0,78 & 0,002 \\
1450 Hiper B Si & 0,68 & 0,21 \\
1500 Esteq A Si & 0,93 & 0,01 \\
1500 Hiper A Si & 0,66 & 0,11 \\
1500 Hipo A Si & 0,88 & 0,02 \\
1500 Esteq M Si & 0,84 & 0,016 \\
1500 Hiper M Si & 0,81 & 0,05 \\
1500 Hipo M Si & 0,85 & 0,001 \\
1500 Esteq B Si & 0,64 & 0,002 \\
1500 Hiper B Si & 0,24 & 0,02 \\
\hline
\end{tabular}

As atividades do silício e do carbono no metal foram calculadas considerando os parâmetros de interação apresentados na Tabela 6.

Tabela 6. Parâmetros de interação ${ }^{[84]}$.

\begin{tabular}{c|cccc}
\hline \multirow{2}{*}{ Elementos } & \multicolumn{4}{|c}{ Parâmetros de interação } \\
\cline { 2 - 5 } & Enxofre & Carbono & Silício & Fósforo \\
\hline Carbono & 0,046 & 0,14 & 0,08 & 0,051 \\
Silício & 0,056 & 0,18 & 0,11 & 0,11 \\
\hline
\end{tabular}

Com os dados do silício e carbono (no tempo de 15 minutos de experimento) e os parâmetros de interação, foi possível o cálculo das atividades henrianas do carbono e do silício no metal.

Após os cálculos das atividades do carbono e do silício do metal e os cálculos das atividades dos óxidos na escória, foi possível calcular a variação da energia livre das reações. A Tabela 7 apresenta os resultados das variações das energias livres das reações de redução do FeO pelo carbono e pelo silício. 
Tabela 7. Variação da energia Livre de Gibbs das reações de redução do $\mathrm{FeO}(\mathrm{kcal} / \mathrm{mol})$.

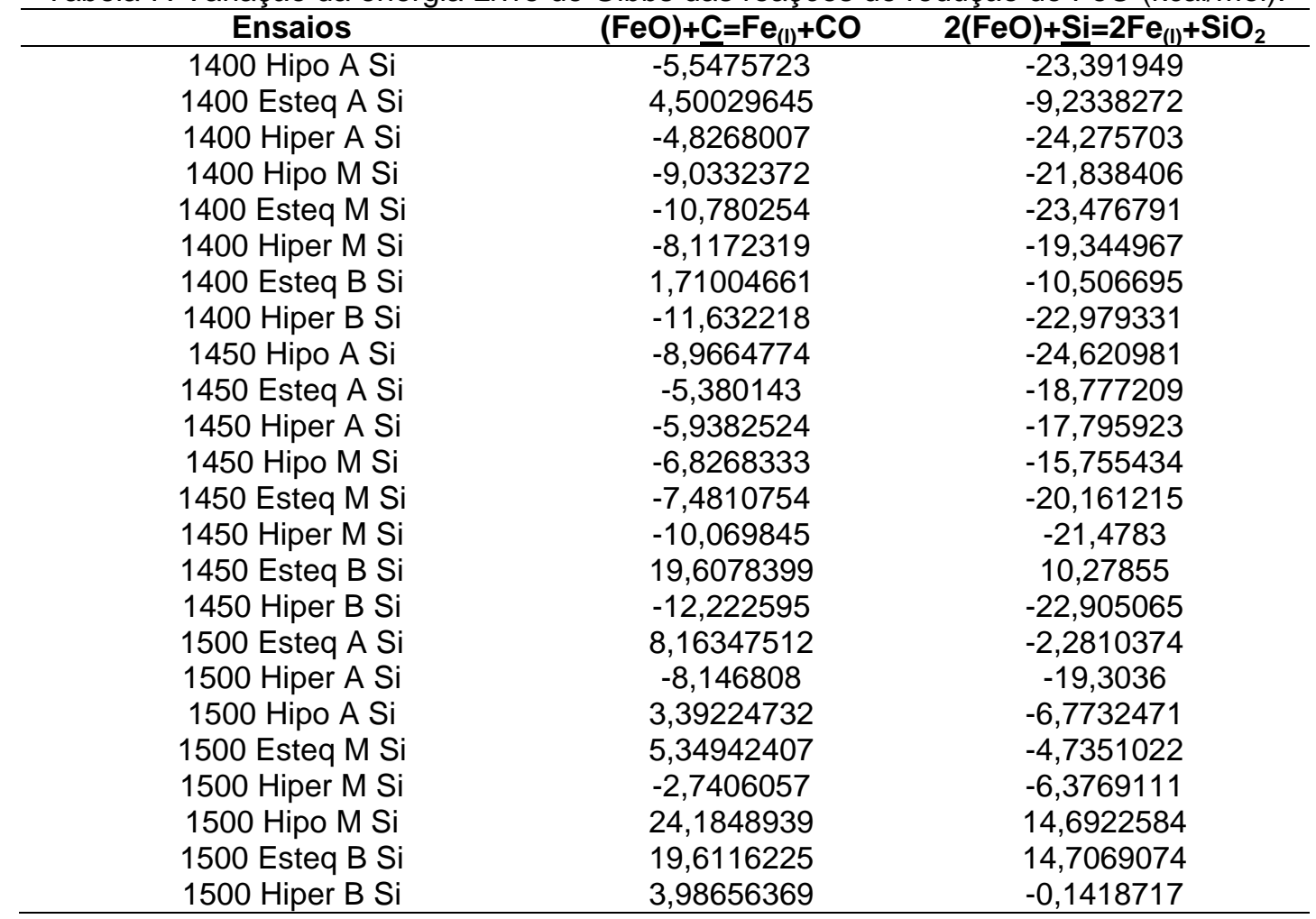

Analisando a Tabela 7, verifica-se que as reações de redução do $\mathrm{FeO}$ pelo silício e pelo carbono, em alguns casos (atividade do $\mathrm{FeO}$ superior a 0,02) possuem potencial termodinâmico para ocorrerem. Entretanto, quando a atividade do $\mathrm{FeO}$ é 0,001 ou 0,002 , as reações não possuem potencial termodinâmico para ocorrerem. A Tabela 8 apresenta os resultados das variações das energias livres de Gibbs das reações de redução do $\mathrm{FeO}$ pelo carbono e pelo silício. 
Tabela 8. Variação da energia livre de Gibbs das reações de redução do $\mathrm{SiO}_{2}(\mathrm{kcal} / \mathrm{mol})$.

\begin{tabular}{|c|c|c|}
\hline Ensaios & $\left(\mathrm{SiO}_{2}\right)+2 \mathrm{C}=\mathrm{Si}+2 \mathrm{CO}$ & $\left(\mathrm{SiO}_{2}\right)+2 \mathrm{Fe}=2(\mathrm{FeO})+\mathrm{Si}$ \\
\hline 1400 Hipo A Si & $-8,4307211$ & 17,60022883 \\
\hline 1400 Esteq A Si & $-13,186456$ & 3,084116972 \\
\hline 1400 Hiper A Si & $-7,5880234$ & 18,59413385 \\
\hline 1400 Hipo M Si & $-13,832818$ & 15,88145997 \\
\hline 1400 Esteq M Si & $-13,572612$ & 17,90537246 \\
\hline 1400 Hiper M Si & $-15,38145$ & 13,82862377 \\
\hline 1400 Esteq B Si & $-14,800116$ & 4,673668516 \\
\hline 1400 Hiper B Si & $-15,774$ & 15,23601619 \\
\hline 1450 Hipo A Si & $-12,951252$ & 17,99348968 \\
\hline 1450 Esteq A Si & $-14,944551$ & 12,41914454 \\
\hline 1450 Hiper A Si & $-16,236099$ & 11,82072832 \\
\hline 1450 Hipo M Si & $-19,332797$ & 9,383189005 \\
\hline 1450 Esteq M Si & $-15,583319$ & 14,03003606 \\
\hline 1450 Hiper M Si & $-17,321468$ & 15,26203877 \\
\hline 1450 Esteg B Si & $-19,266321$ & $-16,494811$ \\
\hline 1450 Hiper B Si & $-17,897819$ & 16,36265585 \\
\hline 1500 Esteg A Si & $-19,74679$ & $-4,27468263$ \\
\hline 1500 Hiper A Si & $-18,460513$ & 12,74787954 \\
\hline 1500 Hipo A Si & $-19,916384$ & 0,217527123 \\
\hline 1500 Esteg M Si & $-19,611395$ & $-1,82061784$ \\
\hline 1500 Hiper M Si & $-26,126555$ & $-0,17880892$ \\
\hline 1500 Hipo M Si & $-20,890423$ & $-21,2479784$ \\
\hline 1500 Esteq B Si & $-25,170963$ & $-21,2626274$ \\
\hline 1500 Hiper B Si & $-25,359127$ & $-6,41384825$ \\
\hline
\end{tabular}

Analisando os dados e fazendo uma correlação com os experimentos, observa-se que a reação de redução do $\mathrm{SiO}_{2}$ pelo carbono é termodinamicamente possível, com isso, o silício reverte para o banho conforme observado nos experimentos. Observa-se também que o aumento da temperatura favorece tanto a reação de redução do FeO pelo carbono, como a reação de redução da sílica pelo carbono. Este comportamento é comprovado através da utilização da termodinâmica computacional (Thermocalc). A Figura 22 apresenta o comportamento do carbono em relação à temperatura. 


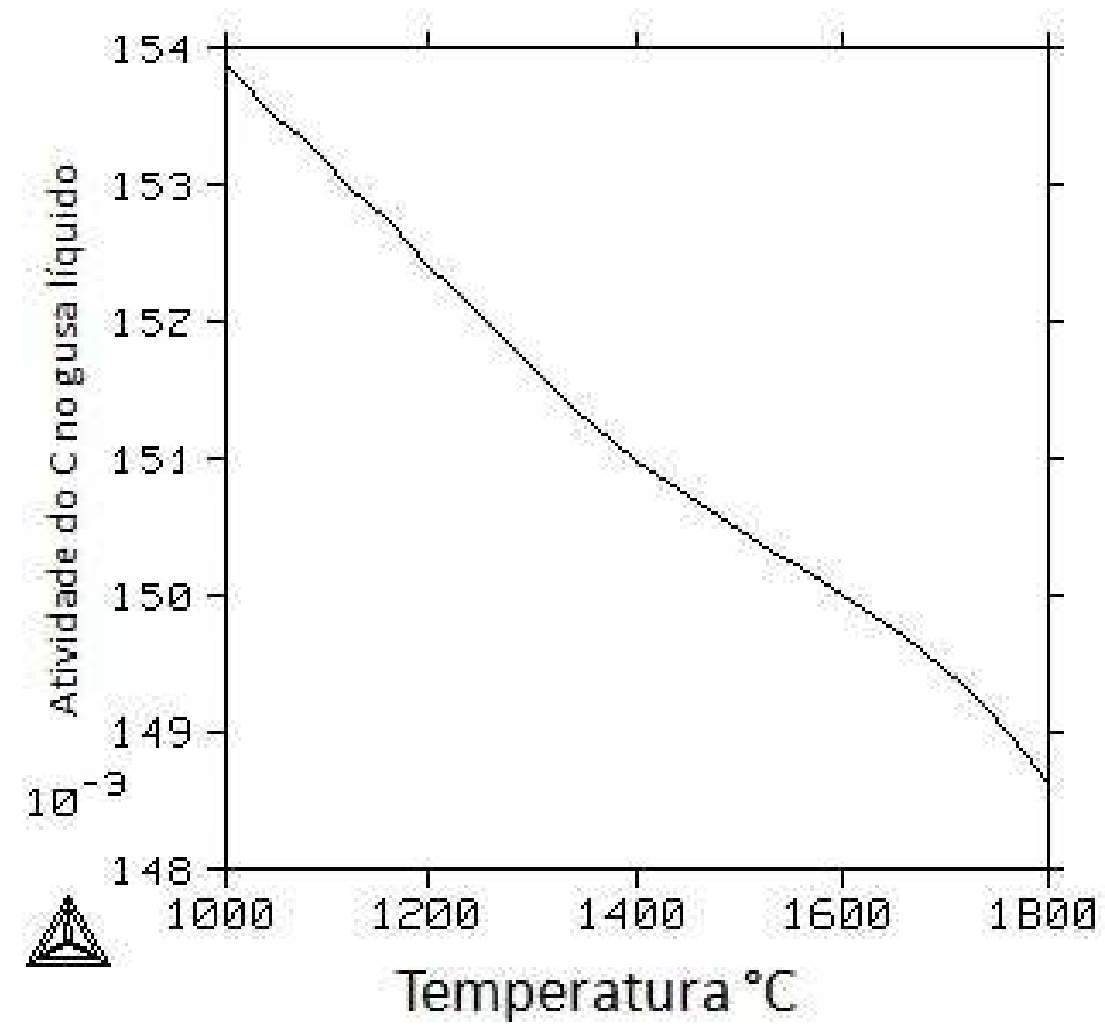

Figura 22. Comportamento do carbono do ferro gusa.

Analisando a figura 22, observa-se que a fração molar do carbono no equilíbrio tende a diminuir com o aumento da temperatura.

A redução do $\mathrm{SiO}_{2}$ possui condições termodinâmicas de ocorrer, mas vai depender das atividades do $\mathrm{FeO}$ e do $\mathrm{SiO}_{2}$ na escória e do Si no metal, além da temperatura, sendo favorecida com o aumento da temperatura.

Após a reversão do silício e o aumento da atividade do mesmo no metal, a reação de redução do $\mathrm{FeO}$ pelo silício e carbono é novamente favorecida. Entretanto, vai depender da atividade do $\mathrm{FeO}$ na escória.

Segundo Silva ${ }^{[68]}$ a reação de redução da $\mathrm{SiO}_{2}$ pelo carbono é favorecida pelas altas temperaturas. 


\subsubsection{Análise da influência da massa de PAE}

A Figura 23 e a Figura 24 apresentam o comportamento do silício em relação ao tempo, variando a massa de poeira adicionada.

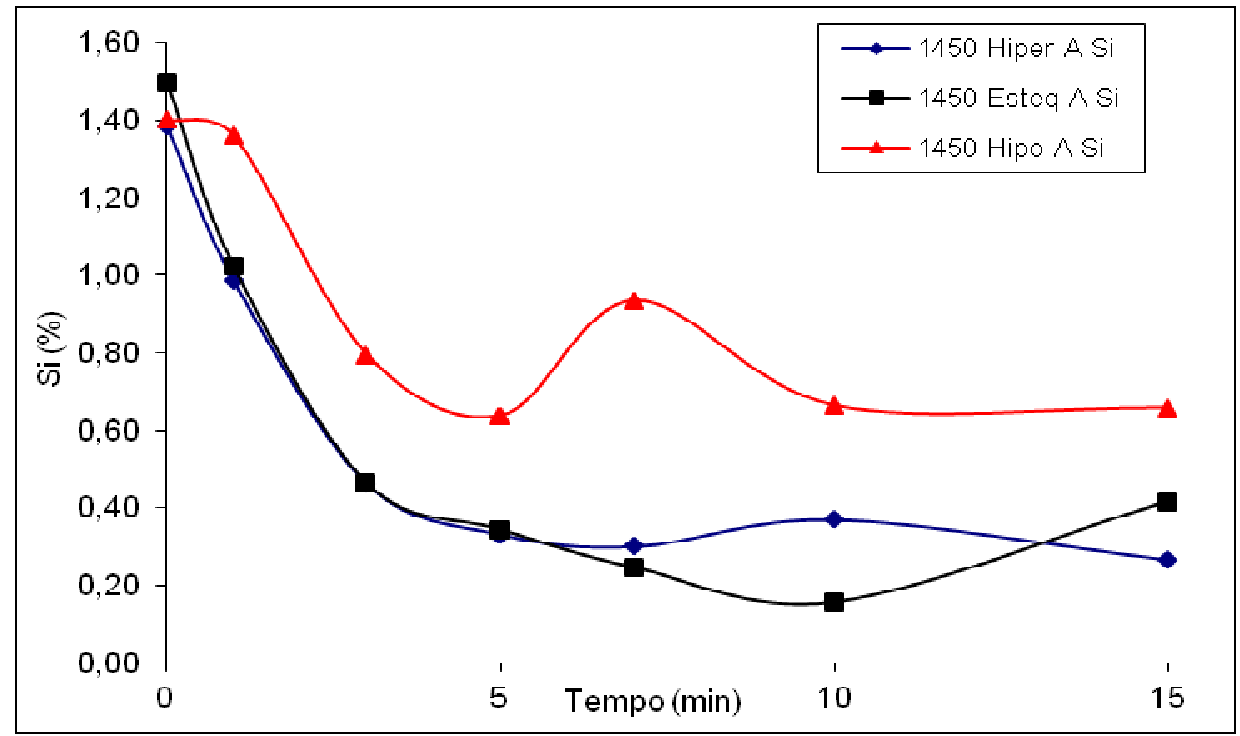

Figura 23. Variação da porcentagem de Si em relação ao tempo na temperatura de $1450{ }^{\circ} \mathrm{C}$.

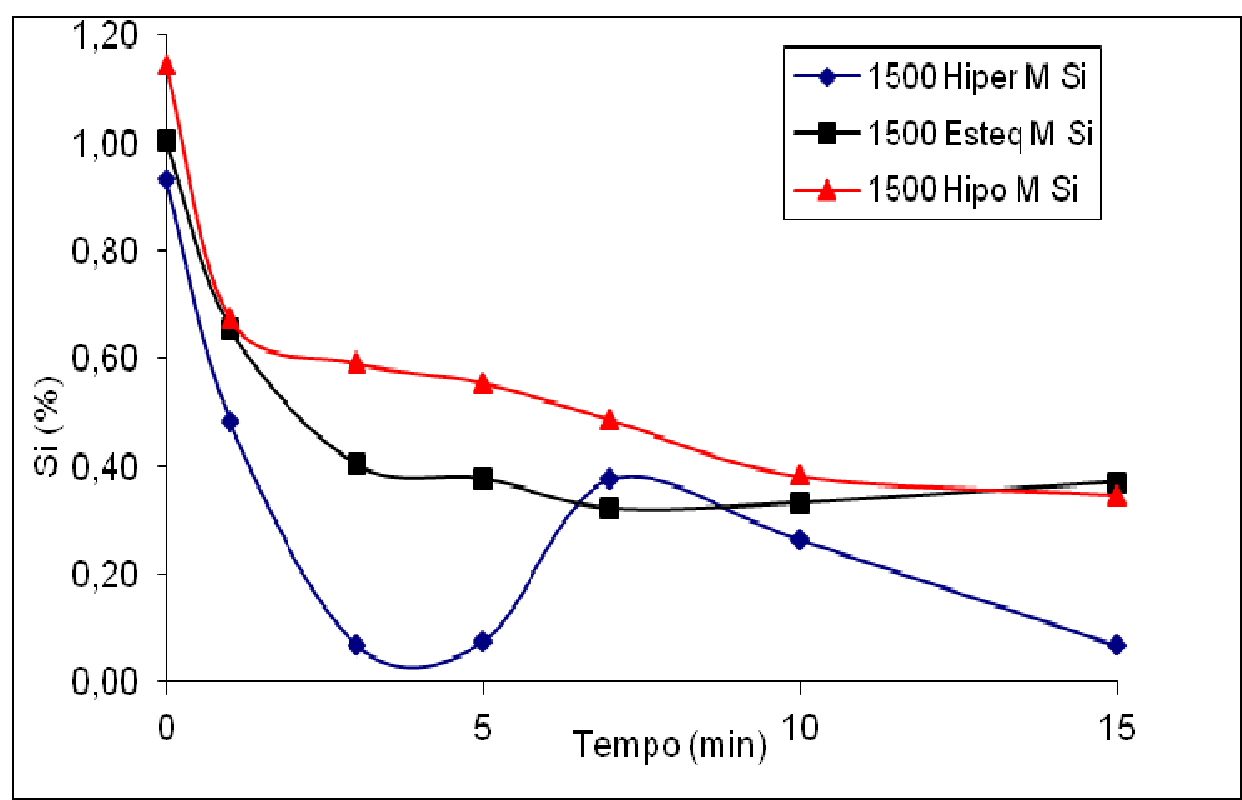

Figura 24. Variação da porcentagem de Si em relação ao tempo na temperatura de $1500{ }^{\circ} \mathrm{C}$.

Verifica-se na Figura 23 e na Figura 24, que o aumento da adição de massa de PAE, apresenta tendência a favorecer a dessiliciação do ferro gusa, comportamento este verificado nas demais classes de experimentos. 


\subsection{CARACTERIZAÇÃO DA POEIRA RESULTANTE DO PROCESSO}

\subsubsection{Análise Química}

O resultado da análise química da poeira volatilizada é apresentado na Tabela 9.

Tabela 9. Composição química elementar da poeira resultante do processo por FRX.

\begin{tabular}{cr}
\hline Elemento & Composiç \\
$\mathrm{Fe}_{\text {total }}$ & 2,4 \\
$\mathrm{Zn}_{\text {total }}$ & 52,54 \\
$\mathrm{Ca}$ & 0,22 \\
$\mathrm{Si}$ & 0,37 \\
$\mathrm{Mn}$ & 0,0 \\
$\mathrm{Mg}$ & 0,2 \\
$\mathrm{Cl}$ & 5,83 \\
$\mathrm{~K}$ & 2,53 \\
$\mathrm{~Pb}$ & 2,00 \\
$\mathrm{~S}$ & 0,28 \\
$\mathrm{Al}$ & 0,2 \\
\hline
\end{tabular}

$\mathrm{Fe}_{\text {total }}$ corresponde ao metal na forma de $\mathrm{Fe}, \mathrm{Fe}_{3} \mathrm{O}_{4}, \mathrm{Fe}_{2} \mathrm{O}_{3}, \mathrm{FeO} \mathrm{ZnO}$ e de ferro associado com o $\mathrm{Zn}\left(\mathrm{ZnFe}_{2} \mathrm{O}_{4}\right) ; \mathrm{Zn}$ total corresponde ao metal na forma de $\mathrm{Zn}$, $\mathrm{ZnO}$ e de zinco associado com o $\mathrm{Fe}\left(\mathrm{ZnFe}_{2} \mathrm{O}_{4}\right)$

Observa-se que o teor de Fe diminui de 38,9 para 2,41\% e o teor de $\mathrm{Zn}$ aumenta de 11,7 para $52,54 \%$ quando comparados com os valores apresentados pela PAE na forma "como recebido".

Em estudos realizados por Mantovani, Takano e Buchler ${ }^{[89]}$, a análise química da poeira coletada durante os experimentos resultou no teor de $55,80 \%$ de zinco e $3,12 \%$ de ferro total. Neste mesmo estudo, segundo os autores a presença de ferro na nova poeira coletada, deve se ao fato da ruptura de bolhas de $\mathrm{CO}$, que projetam metal e são recolhidos pelo sistema de despoeiramento.

De acordo com a ABNT NBR 10004:2004 ${ }^{[75]}$, no Anexo B, fonte geradora: ferro e aço e o código de identificação: K061, a PAE estudada devido a presença de chumbo é considerada um resíduo perigoso de fonte específica, 
porém o teor de zinco $(52,54 \%)$ é compatível com o teor de zinco do concentrado de minério importado (52\%) e superior ao teor de zinco dos minérios nacionais (12 a 39\%).

\subsubsection{Análise granulométrica}

A Figura 25 apresenta a distribuição do tamanho da partícula da poeira resultante do processo.

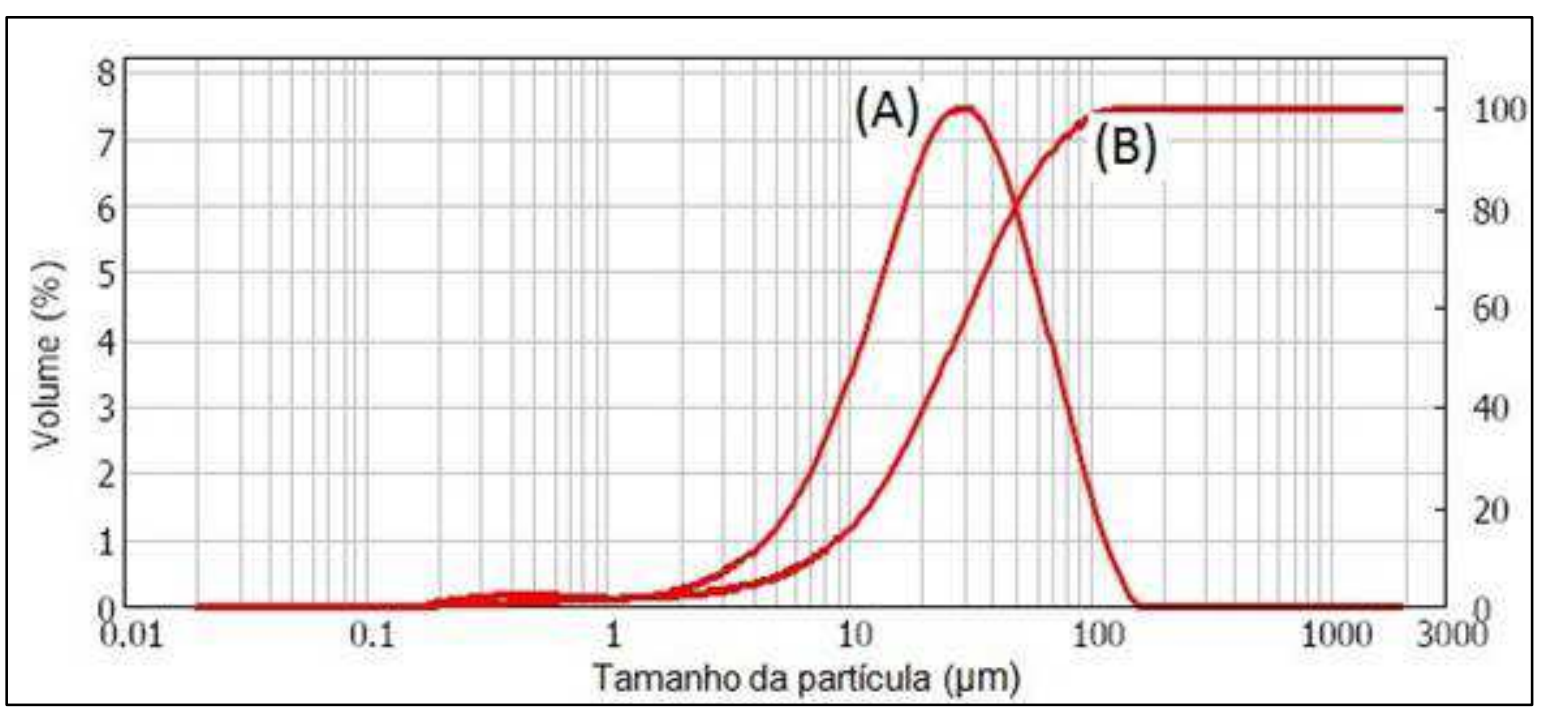

Figura 25. Distribuição granulométrica da poeira resultante do processo.

A linha $(A)$ representa o tamanho da partícula, a linha (B) representa a porcentagem acumulada.

A tabela expedida pelo equipamento, relata que $10 \%$ da amostra possui diâmetro da partícula menor de $7,438 \mu \mathrm{m}$ e que $90 \%$ do material apresenta granulometria inferior a 66,736 $\mu \mathrm{m}$. O resultado da área de superfície específica das partículas foi de $0,58 \mathrm{~m}^{2} / \mathrm{g}$ e o diâmetro médio da partícula $25,886 \mu \mathrm{m}$.

Comparando com os dados da PAE na forma "como recebido" (diâmetro médio da partícula $2,281 \mu \mathrm{m}$ ) conclui-se que o tamanho da partícula da poeira resultante do processo $(25,886 \mu \mathrm{m})$ é maior; pelo fato da não predominância da 
formação das bolhas de monóxido de carbono. Outro dado que comprova a afirmação acima é que a PAE na forma "como recebido" possui $90 \%$ das partículas com granulometria abaixo de $17,070 \mu \mathrm{m}$ enquanto a PAE volatilizada possui $90 \%$ das partículas com granulometria abaixo de $66,736 \mu \mathrm{m}$.

\subsubsection{Difração de raios-X}

A Figura 26 apresenta o espectro de difração de raios-X da amostra de poeira resultante do processo.

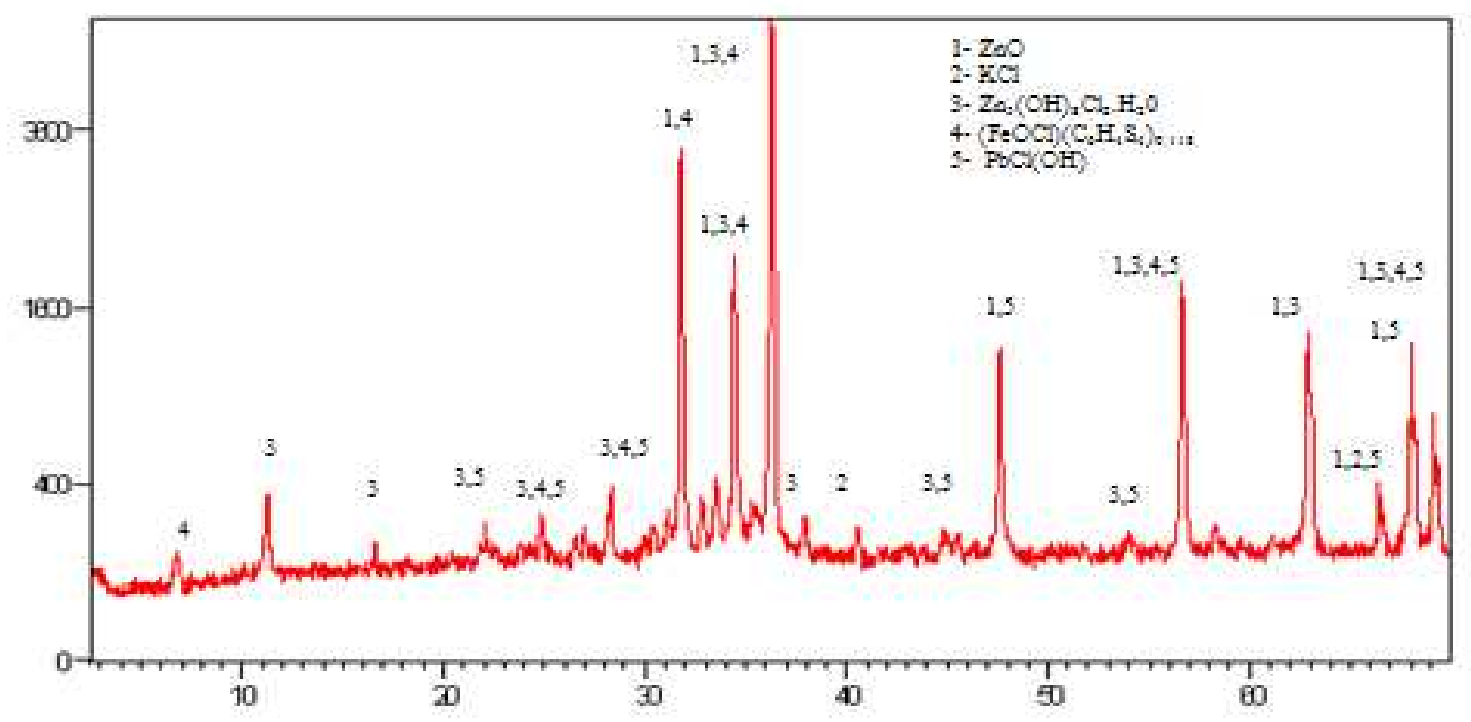

Figura 26. Composição mineralógica da poeira resultante do processo por DRX.

Observa-se na Figura 26 a predominância de óxido de zinco $(\mathrm{ZnO})$ e do composto denominado Simonkolleite $\left(\mathrm{Zn}_{5}(\mathrm{OH})_{8} \mathrm{Cl}_{2} \cdot \mathrm{H}_{2} \mathrm{O} / \mathrm{ZnCl}_{2} \cdot 4 \mathrm{Zn}(\mathrm{OH})_{2} \cdot \mathrm{H}_{2} \mathrm{O}\right)$. Apresenta ainda as fases de silvita $(\mathrm{KCl})$, iron oxide chloride tetrathiofulvalene $\left((\mathrm{FeOCl})\left(\mathrm{C}_{6} \mathrm{H}_{4} \mathrm{~S}_{4}\right)_{0,118}\right)$ e laurionite $(\mathrm{PbCl}(\mathrm{OH}))$. A presença de Magnetita $\left(\mathrm{Fe}_{3} \mathrm{O}_{4}\right)$, Magnesioferrita $\left(\mathrm{MgFe}_{2} \mathrm{O} 4\right)$ e Franklinita $\left(\mathrm{ZnFe}_{2} \mathrm{O}_{4}\right)$ predominantes na PAE como recebido, não foram detectadas. 
Estudos realizados por Grillo ${ }^{[81]}$ não detectaram a presença de ferrita de zinco $\left(\mathrm{ZnFe}_{2} \mathrm{O}_{3}\right)$ na poeira coletada.

Segundo Menad ${ }^{[78]}$ a presença da ferrita de zinco depende da porcentagem de zinco e ferro na poeira coletada. Aproximadamente 50 a $80 \%$ do zinco contido na poeira está na forma de $\mathrm{ZnO}$ e o restante pode estar combinado na forma de ferrita de zinco $\left(\mathrm{ZnO} \cdot \mathrm{Fe}_{2} \mathrm{O}_{3}\right)$.

\subsubsection{Microscopia Eletrônica de Varredura e Análise de Micro-Regiões por EDS}

A Figura 27 apresenta a imagem de partículas de poeira resultante do processo obtidas em MEV.

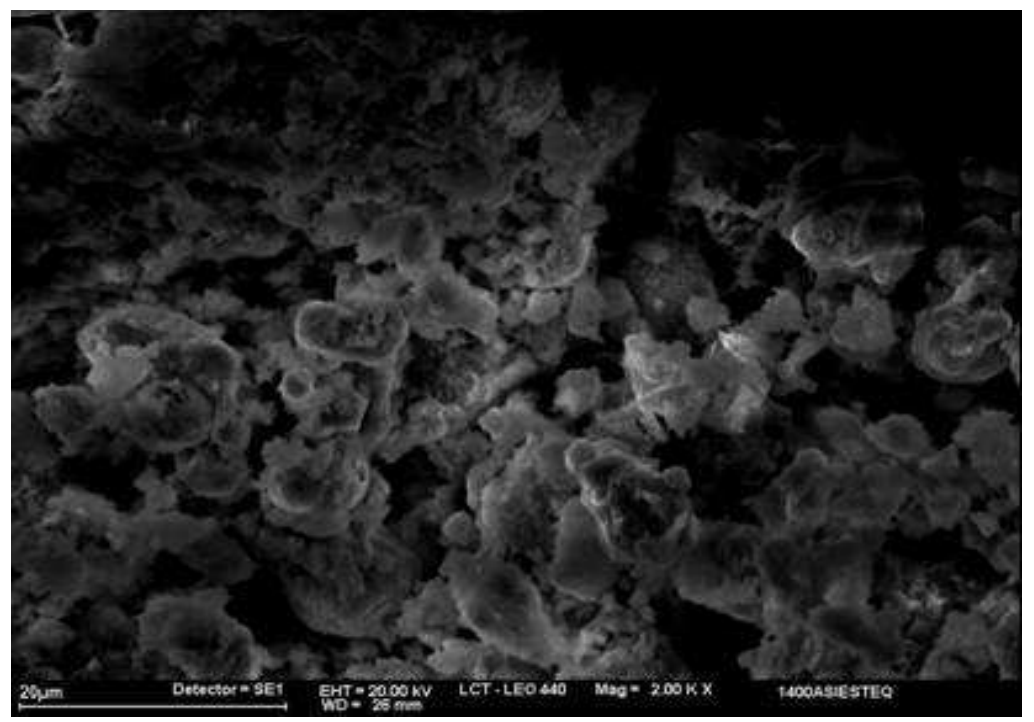

Figura 27. Imagem de partículas de poeira resultante do processo obtida em MEV.

Verifica-se que a poeira volatilizada, resultante do processo é constituída predominantemente de partículas de formato lamelar apesar da presença de partículas de formato esférico. Este formato é diferente do formato das partículas da PAE na forma "como recebido", devido a sua formação ser principalmente oriunda da volatilização de zinco contido na PAE originalmente 
adicionada e não pelo arraste de gotículas de metal e escória provocados pela agitação do forno industrial.

Nos estudos realizados por Grillo ${ }^{[81]}$ e Mantovani, Takano e Buchler ${ }^{[89]}$ também foi observado a morfologia esférica e lamelar da poeria coletada.

A Figura 28 apresenta a análise por EDS da poeira resultante do processo.

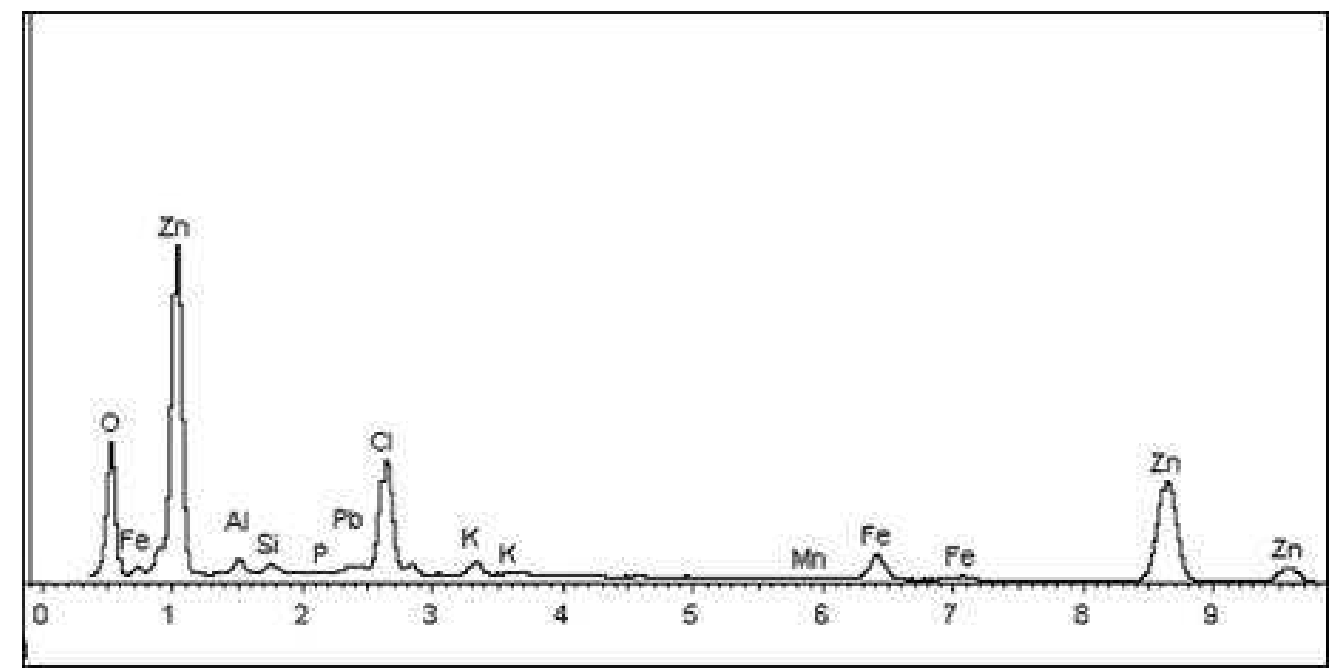

Figura 28. Espectro de EDS da região da lamela da poeira produzida pelo processo.

Observa-se que o elemento químico predominante é o zinco, porém nota-se a presença de cloro, chumbo e ferro (elementos químicos constituintes da PAE "como recebido"). A análise semi-quantitativa e pontual apresentou resultado de $52,20 \%$ de zinco e $4,60 \%$ de ferro.

\subsection{CARACTERIZAÇÃO DAS ESCÓRIAS RESULTANTES DOS EXPERIMENTOS}

Neste ítem é realizada uma análise termodinâmica, utilizando os resultados da composição química da escória final dos experimentos. 
Partindo destes resultados foram realizadas simulações nos programas Thermocalc e Factsage visando conhecer propriedades das escórias.

O resultado das análises químicas semi-quantitativa das amostras de escória final de cada experimento é apresentado na Tabela 10.

Tabela 10. Composição química de escória final por EDS

\begin{tabular}{|c|c|c|c|c|c|c|c|c|}
\hline Ensaios & $\mathrm{MgO}$ & $\mathrm{Al}_{2} \mathrm{O}_{3}$ & $\mathrm{SiO}_{2}$ & $\mathrm{~K}_{2} \mathrm{O}$ & $\mathrm{CaO}$ & MnO & $\mathrm{FeO}$ & ZnO \\
\hline 1400 Hipo A Si & 2,49 & 11,46 & 38,25 & 0,56 & 4,96 & 2,50 & 14,30 & 0,61 \\
\hline 1400 Esteq A Si & 0,71 & 5,30 & 40,28 & 0,91 & 0,75 & 0,90 & 6,75 & 33,06 \\
\hline 1400 Hiper A Si & 0,96 & 5,92 & 36,18 & 0,71 & 3,23 & 1,87 & 12,21 & 22,28 \\
\hline 1400 Hipo M Si & 2,76 & 9,22 & 39,72 & 0,49 & 6,11 & 7,24 & 17,10 & 3,00 \\
\hline 1400 Esteq M Si & 2,49 & 4,39 & 40,21 & 0,01 & 14,7 & 4,49 & 20,26 & 3,56 \\
\hline 1400 Hiper M Si & 1,71 & 15,97 & 38,02 & 0,95 & 4,81 & 3,53 & 14,54 & 5,11 \\
\hline 1400 Esteq B Si & 3,57 & 6,11 & 46,18 & 0,70 & 9,26 & 8,29 & 4,33 & 0,02 \\
\hline 1400 Hiper B Si & 2,18 & 10,68 & 44,24 & 0,00 & 0,31 & 0,22 & 26,80 & 0,15 \\
\hline 1450 Hipo A Si & 3,77 & 9,58 & 42,21 & 0,60 & 5,96 & 4,09 & 14,41 & 1,70 \\
\hline 1450 Esteg A Si & 2,36 & 8,89 & 46,27 & 0,66 & 4,33 & 2,39 & 7,15 & 0,81 \\
\hline 1450 Hiper A Si & 2,27 & 14,27 & 46,57 & 0,86 & 4,68 & 2,82 & 9,41 & 1,51 \\
\hline 1450 Hipo M Si & 5,28 & 11,16 & 49,21 & 0,17 & 4,96 & 2,85 & 13,48 & 3,17 \\
\hline 1450 Esteq M Si & 2,96 & 11,79 & 46,78 & 0,63 & 6,96 & 4,68 & 13,85 & 0,47 \\
\hline 1450 Hiper M Si & 5,23 & 9,90 & 42,26 & 0,40 & 11,10 & 5,53 & 9,59 & 0,94 \\
\hline 1450 Esteq B Si & 3,74 & 16,35 & 40,45 & 0,42 & 3,38 & 1,47 & 0,44 & 0,19 \\
\hline 1450 Hiper B Si & 5,25 & 10,72 & 44,24 & 0,04 & 0,08 & 0,37 & 32,17 & 0,16 \\
\hline 1500 Esteq A Si & 5,60 & 13,40 & 64,90 & 0,91 & 5,98 & 3,27 & 3,16 & 0,90 \\
\hline 1500 Hiper A Si & 4,48 & 12,10 & 52,70 & 0,94 & 6,31 & 4,37 & 15,50 & 2,00 \\
\hline 1500 Hipo A Si & 4,49 & 13,30 & 64,60 & 1,15 & 6,50 & 3,58 & 4,55 & 0,95 \\
\hline 1500 Esteq M Si & 5,66 & 15,30 & 63,28 & 0,80 & 6,19 & 3,61 & 3,02 & 0,44 \\
\hline 1500 Hiper M Si & 4,29 & 13,40 & 60,50 & 0,95 & 6,58 & 4,58 & 7,89 & 1,10 \\
\hline 1500 Hipo M Si & 6,65 & 17,90 & 65,40 & 0,65 & 5,40 & 1,49 & 1,34 & 0,40 \\
\hline 1500 Esteq B Si & 7,91 & 34,00 & 51,70 & 0,38 & 4,00 & 0,30 & 0,67 & 0,19 \\
\hline 1500 Hiper B Si & 10,40 & 32,20 & 38,77 & 0,42 & 13,00 & 1,53 & 2,42 & 0,29 \\
\hline
\end{tabular}

A análise conjunta das escórias permite observar a presença do elemento químico Al. Como o cadinho utilizado nos experimentos foi de alumina, ocorreu o desgaste do cadinho, contribuindo para o aumento de Al na escória. É possível observar o aumento do elemento químico Si na escória em função das reações de oxidação do silício contido no ferro gusa.

Os compostos químicos $\mathrm{FeO}$ e $\mathrm{ZnO}$, mediante análise conjunta, decrescem quando a temperatura aumenta de 1400 para $1500^{\circ} \mathrm{C}$. A Figura 29 , gerada pelo Thermocalc, apresenta o comportamento do ferro na escória em função da temperatura. 


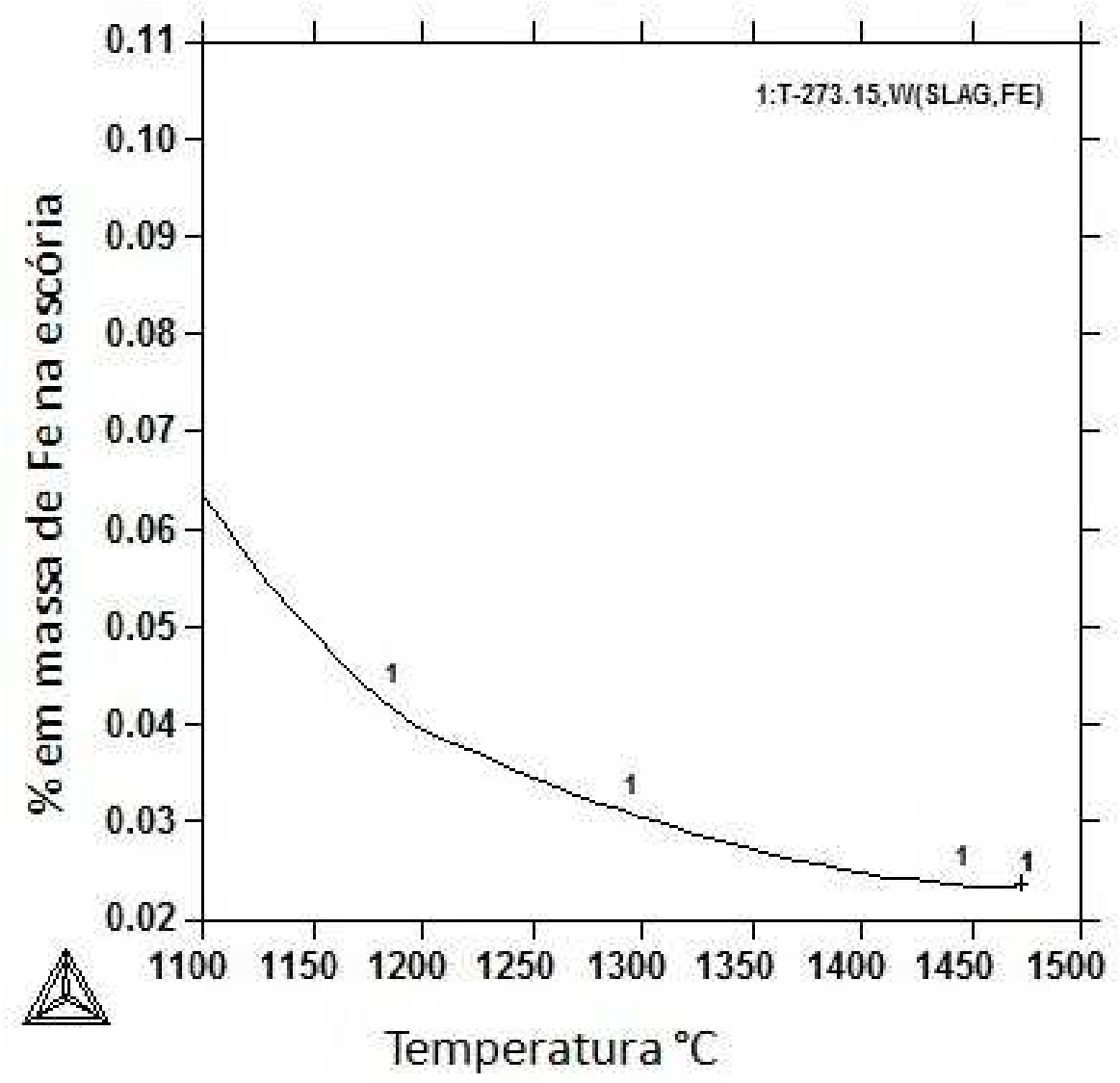

Figura 29. Simulação do teor de ferro na escória.

Através da simulação computacional é possível observar o mesmo comportamento, decréscimo do toer de ferro na escória com o aumento da temperatura.

A Figura 30, gerada também através de simulação computacional (Termocalc), apresenta-se o comportamento do silício na escória. Observa-se que o resultado da simulação computacional e os resultados dos experimentos apresentam convergência. 


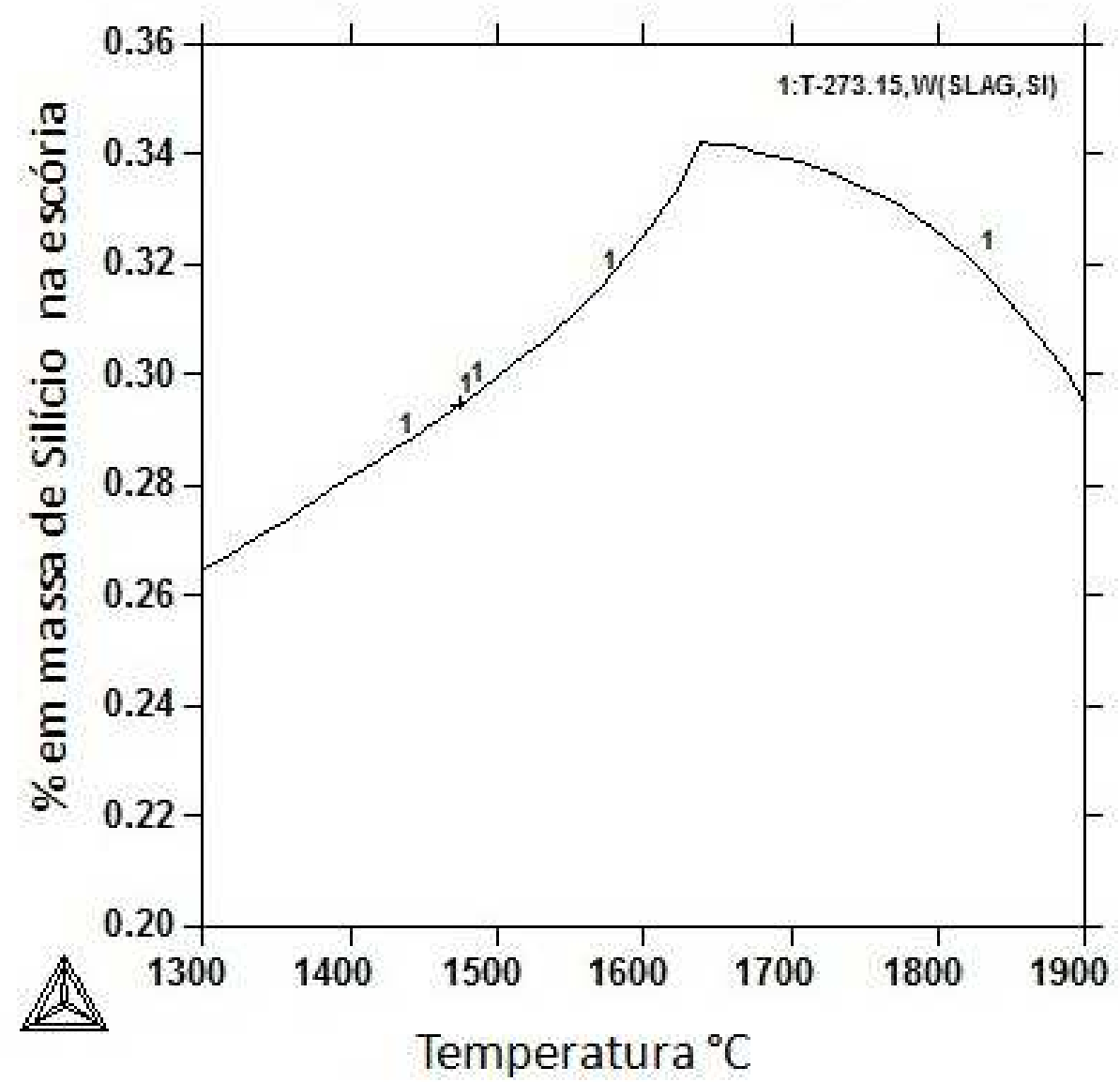

Figura 30. Simulação do teor de Si na escória.

Observa-se que nesta simulação, o teor de silício na escória tende a crescer nas temperaturas dos ensaios. O aumento do teor de silício na escória calculado pelo Thermocalc foi observado nos experimentos realizados em escala laboratorial (Tabela 10).

Com o intuito de conhecer as propriedades das escórias, foi realizado a simulação do aquecimento de 3 escórias. A Figura 31 apresenta o aquecimento da escória final do experimento (1450 Esteq A Si). 


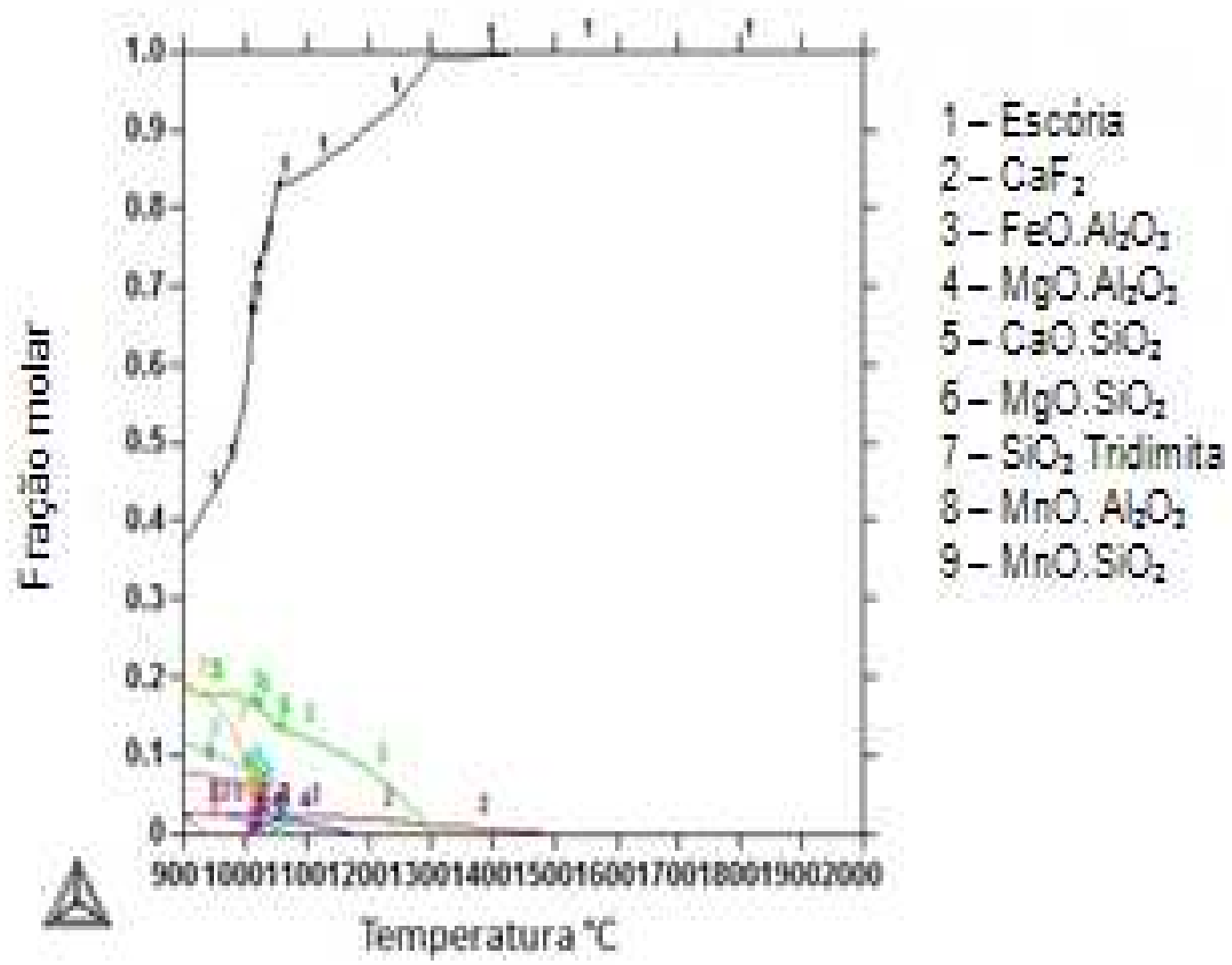

Figura 31. Perfil térmico da escória A Si com poeira estequiométrica.

Analisando a Figura 31, observa-se que a temperatura de fusão desta escória é de aproximadamente $1450^{\circ} \mathrm{C}$. Entre 1300 e $1500^{\circ} \mathrm{C}$ observa-se a presença de uma fração de fase sólida composta por $\left(\mathrm{FeO} \cdot \mathrm{Al}_{2} \mathrm{O}_{3}\right)$ e $\left(\mathrm{CaF}_{2}\right)$. Como o ensaio foi realizado na temperatura de $1450^{\circ} \mathrm{C}$, a escória esteve completamente líquida. A Figura 32 apresenta a simulação do aquecimento da escória final do experimento (1400 Esteq B Si). 


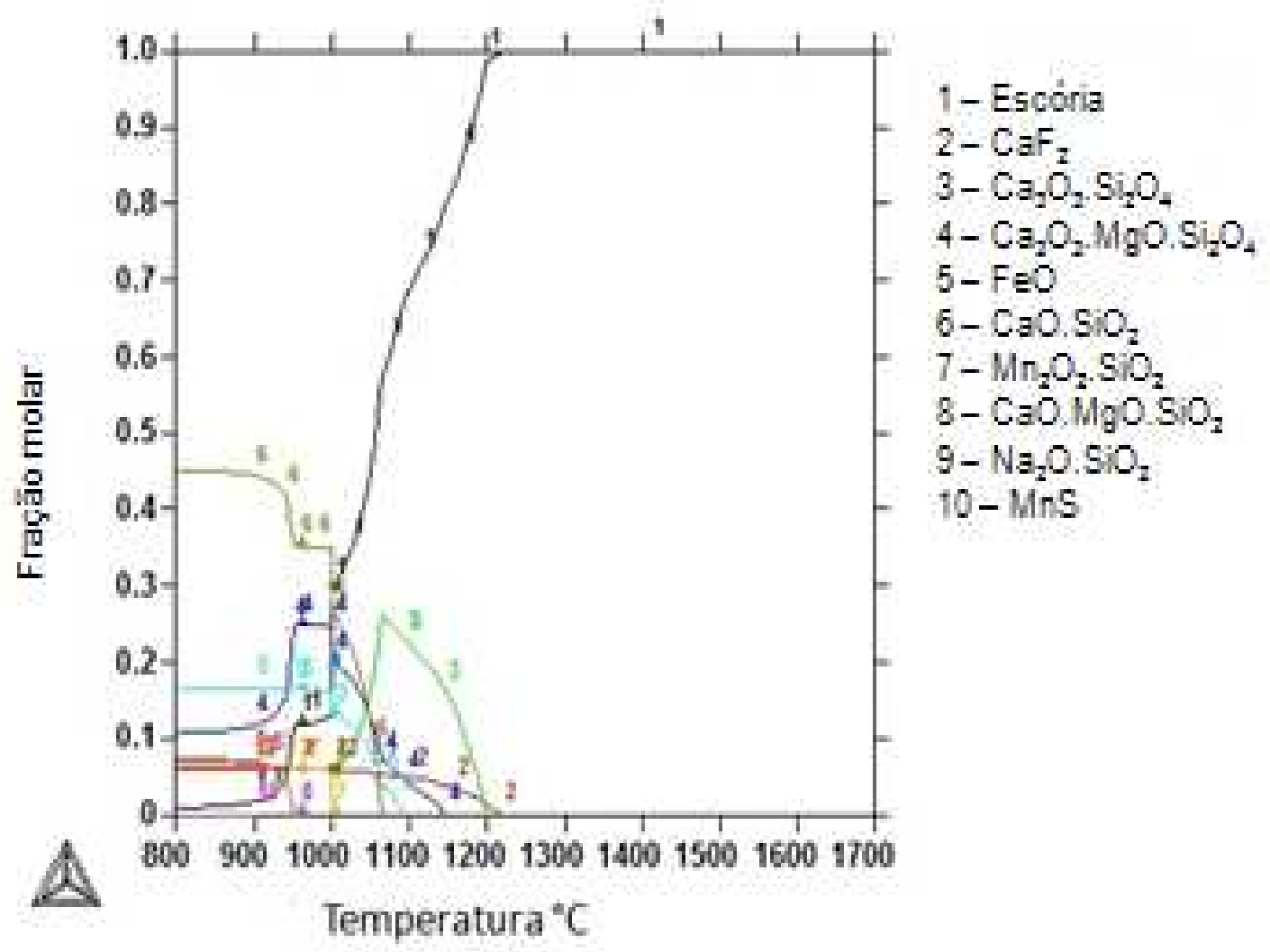

Figura 32. Perfil térmico da escória B Si com poeira estequiométrica.

Analisando a Figura 32 observa-se que na temperatura de experimento $\left(1450^{\circ} \mathrm{C}\right)$ a escória vai estar totalmente líquida. É importante ressaltar para o processo, a fração de fase líquida e os sólidos que se precipitam; estes afetam a cinética do processo de redução. No caso especifico não existe a formação de fase sólida. Através da simulação, obtem-se no experimento uma escória final $100 \%$ líquida.

A Figura 33 apresenta o comportamento dos óxidos no equilíbrio da escória do experimento (1400 esteq Asi) com o aumento da temperatura. 


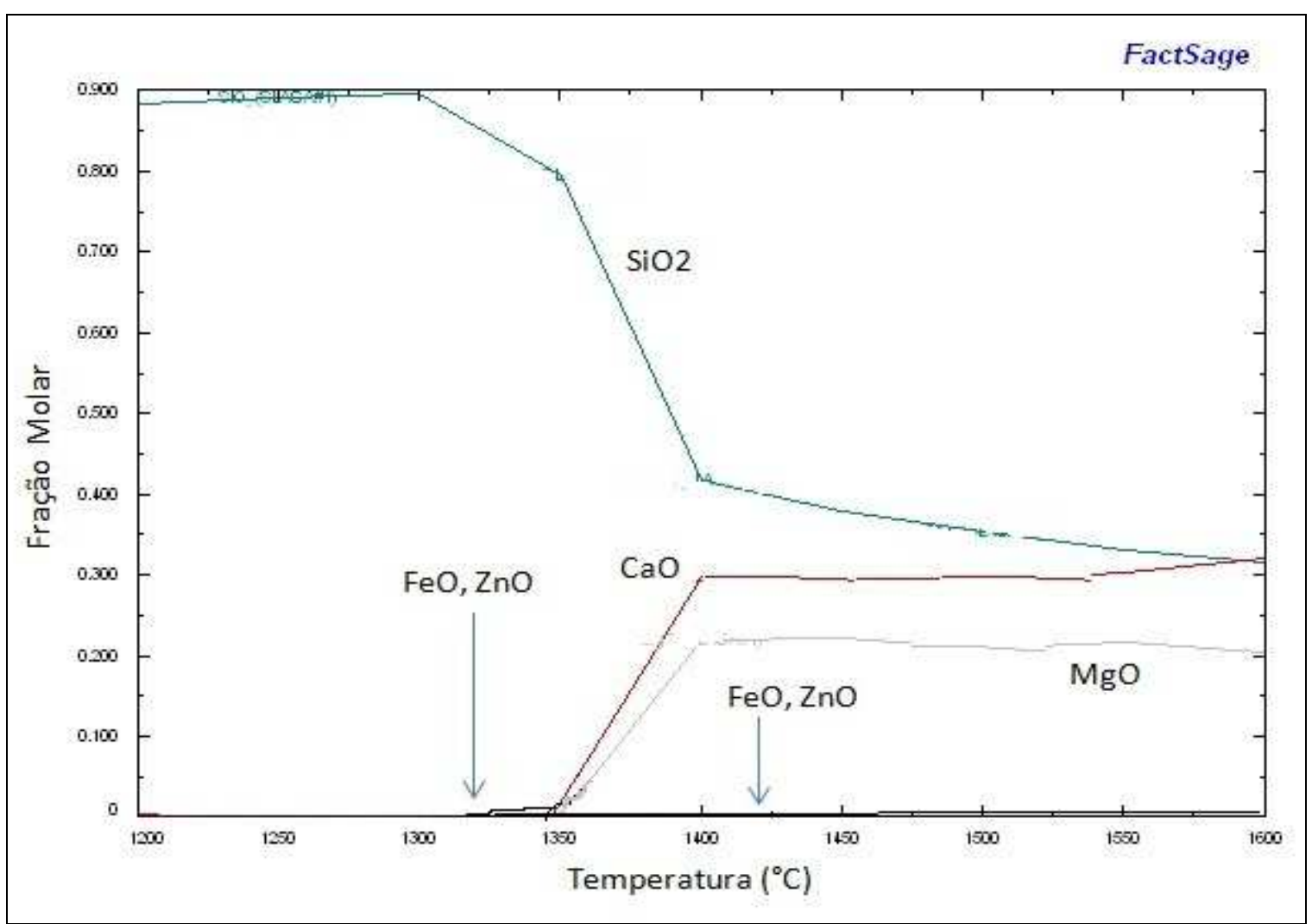

Figura 33. Comportamento dos óxidos na escória (1400esteq Asi) em equilíbrio metal escória.

Analisando a Figura 33 observa-se a presença de ZnO e FeO na escória no equilíbrio. Este resultado significa que não ocorre a completa volatilização do zinco e que parte dele permanece na escória, como pode ser observado na análise química das escórias (Tabela 10).

Em estudos realizados por Yang e Gustasson ${ }^{[90]}$ sobre o reaproveitamento da PAE adicionada em ferro gusa na forma de pelotas e poeira, os autores também observaram a presença de $\mathrm{ZnO}$ e $\mathrm{FeO}$ na escória final dos experimentos.

A Figura 34 apresenta o espectro por EDS da escória final do experimento 1400 Esteq A Si. 


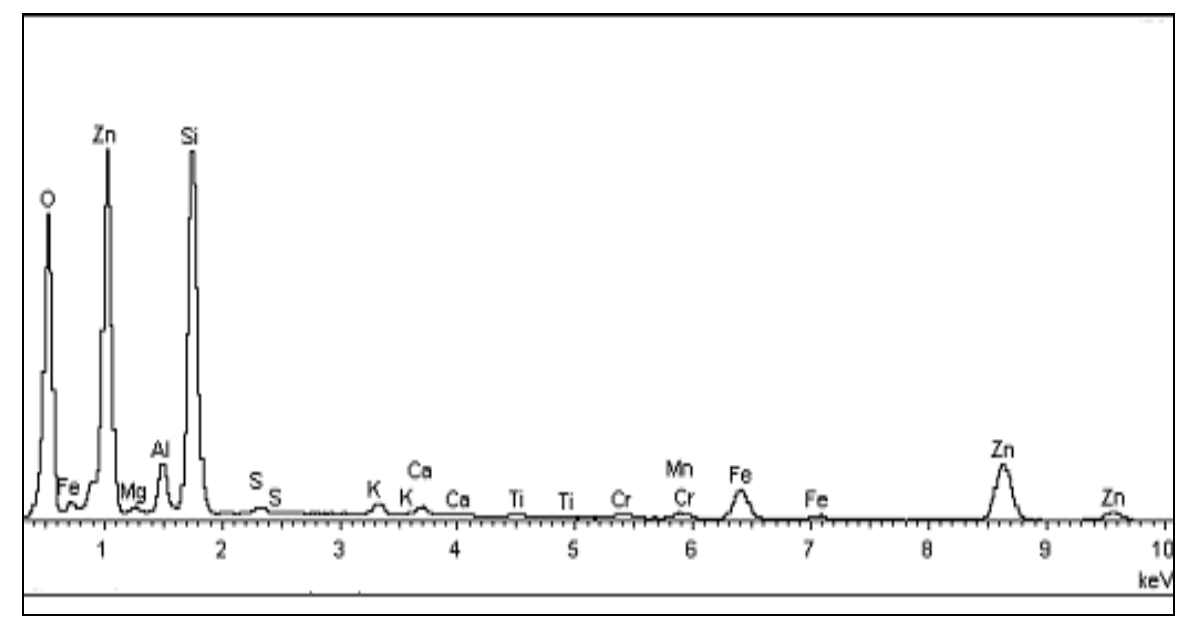

Figura 34. Espectro de EDS da escória final (1400 Esteq A Si).

Observa-se a predominância dos elementos químicos $\mathrm{Zn}$ e Si juntamente com o oxigênio e a presença de elementos como $\mathrm{Fe}, \mathrm{Mg}, \mathrm{S}, \mathrm{Ca}, \mathrm{K}$, $\mathrm{Ti}, \mathrm{Cr}, \mathrm{Mn}$; elementos estes quantificados no resultado da análise química semiquantitativa e pontual da amostra de escória.

\subsubsection{Difração de raios-X}

A Figura 35 apresenta a difração da escória final do experimento (1400EsteqAsi).

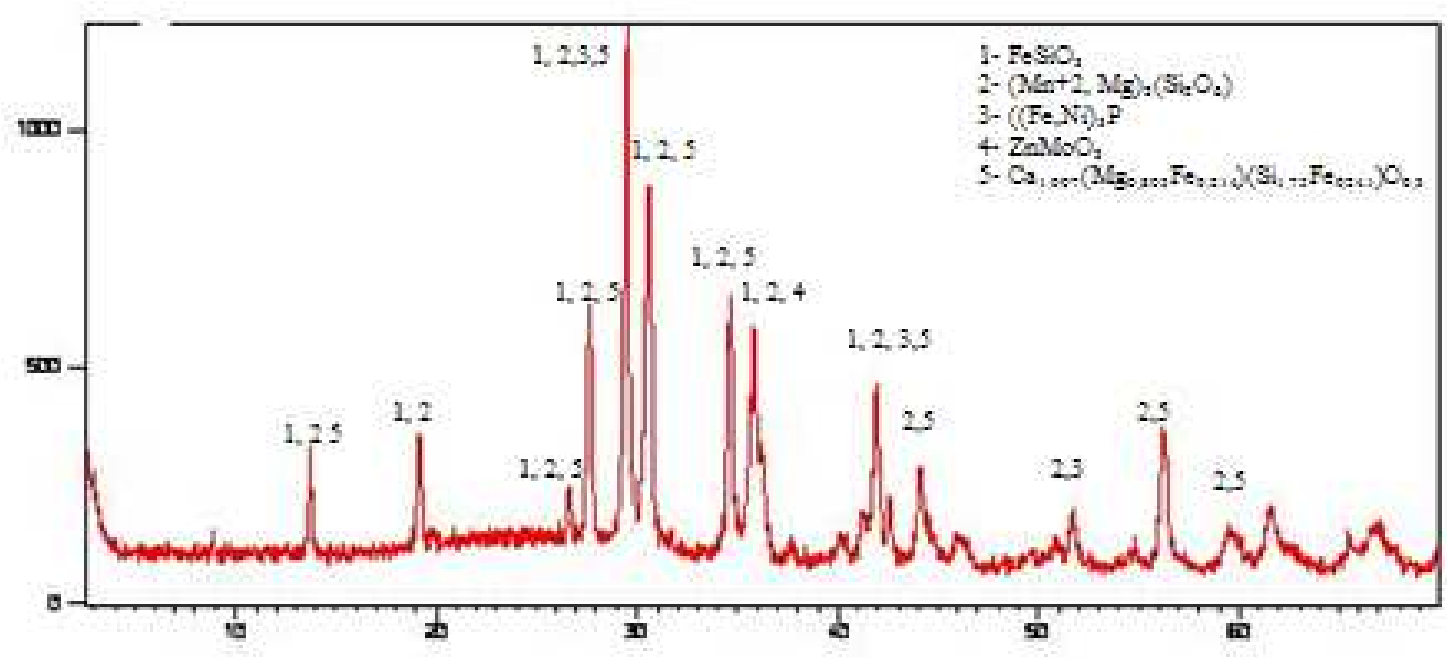

Figura 35. Difração de raios-X da escória final do experimento (1400 Esteq Asi). 
Observa-se na figura 35, que na escória final existe a predominância das fases cinoferrosilite $\left(\mathrm{FeSiO}_{3}\right)$, kanoite $\left(\left(\mathrm{Mn}^{+2}, \mathrm{Mg}\right)_{2}\left(\mathrm{Si}_{2} \mathrm{O}_{6}\right)\right)$ e diopside ferrian $\left(\mathrm{Ca}_{1,007}\left(\mathrm{Mg}_{0,805} \mathrm{Fe}_{0,214}\right)\left(\mathrm{Si}_{1,75} \mathrm{Fe}_{0,241}\right) \mathrm{O}_{0,3}\right)$. A amostra apresenta ainda as fases schreibersite $\left((\mathrm{Fe}, \mathrm{Ni})_{3} \mathrm{P}\right)$ e zinc molybdenium $\left(\mathrm{ZnMoO}_{3}\right)$.

\subsection{ANÁLISE CINÉTICA}

A Figura 36 apresenta a variação do teor de silício no ferro gusa líquido no experimento 1400 Esteq A Si. Através da análise desta curva, obteve-se o teor do silício final que será denominado Sieq.

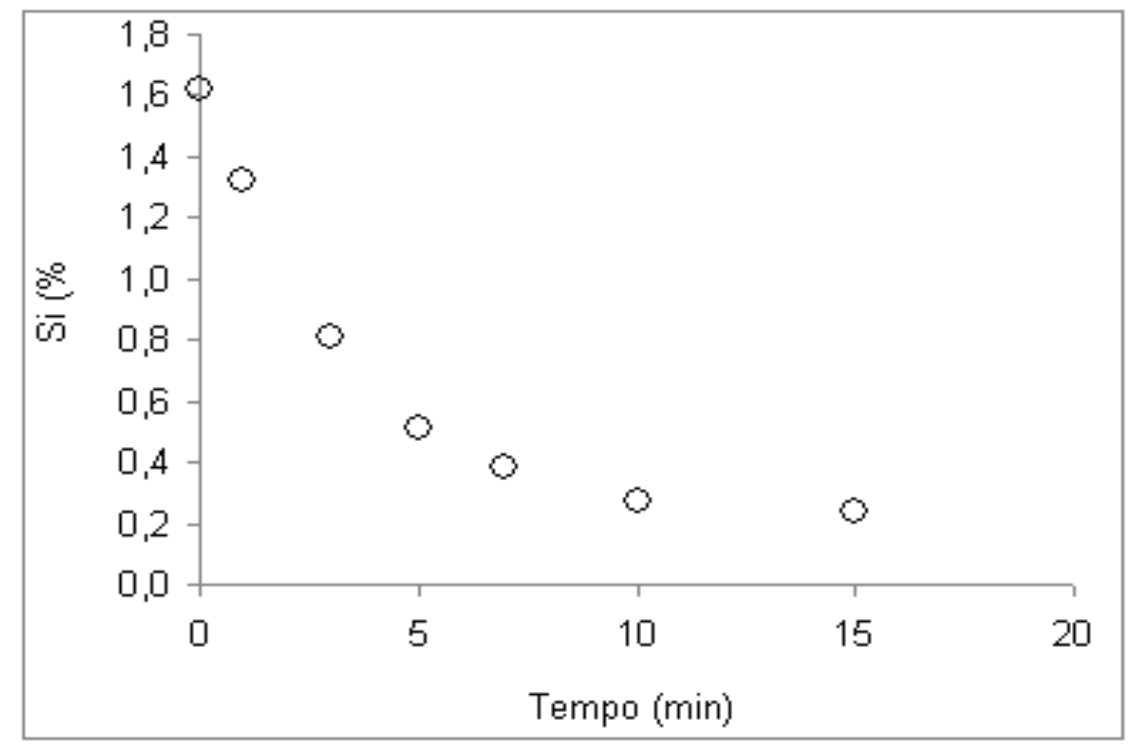

Figura 36. Variação do teor de silício no gusa líquido [1400 Esteq A Si].

Através da análise dos pontos de teor de silício deste experimento, observa-se que o silício final é de $0,20 \%$. Procedimento idêntico foi realizado para os demais experimentos com teores de silício variando de 1,38 a 1,85\% e nos experimentos da classe de adição de PAE em gusa com silício entre 0,23 a 0,35\%, adotando-se o valor do teor de silício final ou o valor mínimo no caso de 
oscilação do teor de silício durante o experimento como valor do teor de silício de equilíbrio (Sieq).

Com os valores de Sieq definidos, a etapa seguinte foi construir a reta $\ln [($ CSi-CSieq)/(CSio-CSieq) $] \times$ Tempo. A Figura 37 apresenta.

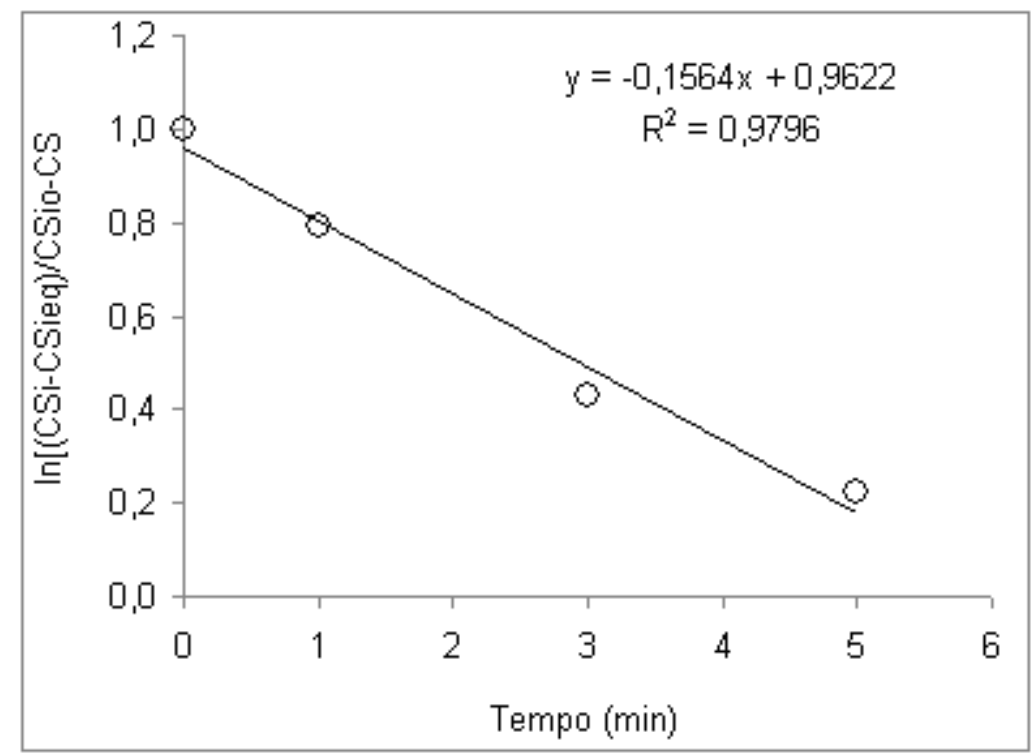

Figura 37. Variação do $\ln [(C S i-C S i e q) /(C S i o-C S i e q)]$.

Observa-se na Figura 37 que foram adotados os valores de variação do teor de silício até o tempo de 5 minutos de experimento, este foi o maior conjunto de dados (mínimo de 3 dados) que apresentou o valor de $\mathrm{R}^{2}$ próximo da unidade. Com o valor da inclinação da reta $(0,1564)$ da Figura 37 , obteve-se o valor da constante cinética de velocidade da reação. Procedimento semelhante foi adotado para os demais experimentos.

A Tabela 11 apresenta os experimentos selecionados e os respectivos valores de silício de equilíbrio, constante cinética de velocidade e $R^{2}$. 
Tabela 11. Valores de Si eq, $\mathrm{Ke}^{2}$.

\begin{tabular}{|c|c|c|c|}
\hline Experimento & Si eq (\%) & $\mathrm{K}\left(\mathrm{min}^{-1}\right)$ & $\mathbf{R}^{2}$ \\
\hline 1400 Esteq B Si & 0,10 & 0,0942 & 0,4171 \\
\hline 1450 Esteq B Si & 0,10 & 0,1908 & 0,2527 \\
\hline 1500 Esteq B Si & 0,04 & 0,2529 & 0,9344 \\
\hline 1400 Hiper B Si & 0,05 & 0,0251 & 0,9854 \\
\hline 1450 Hiper B Si & 0,10 & 0,0714 & 0,5592 \\
\hline 1500 Hiper B Si & 0,04 & 0,1931 & 0,9997 \\
\hline 1400 Hipo M Si & 0,07 & 0,1290 & 0,9240 \\
\hline 1450 Hipo M SI & 0,15 & 0,1340 & 0,8740 \\
\hline 1500 Hipo M Si & 0,40 & 0,2200 & 0,7030 \\
\hline 1400 Esteq M Si & 0,10 & 0,3160 & 0,9930 \\
\hline 1450 Esteq M Si & 0,20 & 0,3180 & 0,7470 \\
\hline 1500 Esteq M Si & 0,30 & 0,2690 & 0,9220 \\
\hline 1400 Hiper M Si & 0,05 & 0,1660 & 0,9960 \\
\hline 1450 Hiper M Si & 0,10 & 0,1600 & 0,9820 \\
\hline 1500 Hiper M Si & 0,05 & 0,3130 & 0,9550 \\
\hline 1350 Hipo A Si & 0,70 & 0,0632 & 0,7116 \\
\hline 1400 Hipo A Si & 0,40 & 0,0564 & 0,8421 \\
\hline 1450 Hipo A Si & 0,60 & 0,0947 & 0,5912 \\
\hline 1500 Hipo A Si & 0,20 & 0,1312 & 0,8996 \\
\hline 1350 Esteq A Si & 0,40 & 0,1381 & 0,9393 \\
\hline 1400 Esteq A Si & 0,20 & 0,1564 & 0,9796 \\
\hline 1450 Esteq A Si & 0,15 & 0,1640 & 0,7841 \\
\hline 1500 Esteq A Si & 0,10 & 0,2307 & 0,9996 \\
\hline 1350 Hiper A Si & 0,40 & 0,0774 & 0,9971 \\
\hline 1400 Hiper A Si & 0,60 & 0,1336 & 0,3907 \\
\hline 1450 Hiper A Si & 0,30 & 0,1931 & 0,9122 \\
\hline 1500 Hiper A Si & 0,02 & 0,2328 & 1,0000 \\
\hline
\end{tabular}

Observa-se que alguns experimentos apresentam valores de $R^{2}$ de 0,$2527 ; 0,3907 ; 0,4171$; estes valores são consequência da oscilação no decrésimo do teor de silício do ferro gusa durante a realização do experimento.

Utilizando os valores obtidos para as constantes cinéticas de velocidade o procedimento seguinte foi construir o gráfico denominado "curva de Arrhenius" para cada classe de experimentos. A curva de Arrhenius para a classe de experimentos de adição de PAE em quantidade estequiométrica em ferro gusa com baixo (0,23 a 0,36\%) teor de silício (Esteq B Si) é apresentada na Figura 38. 


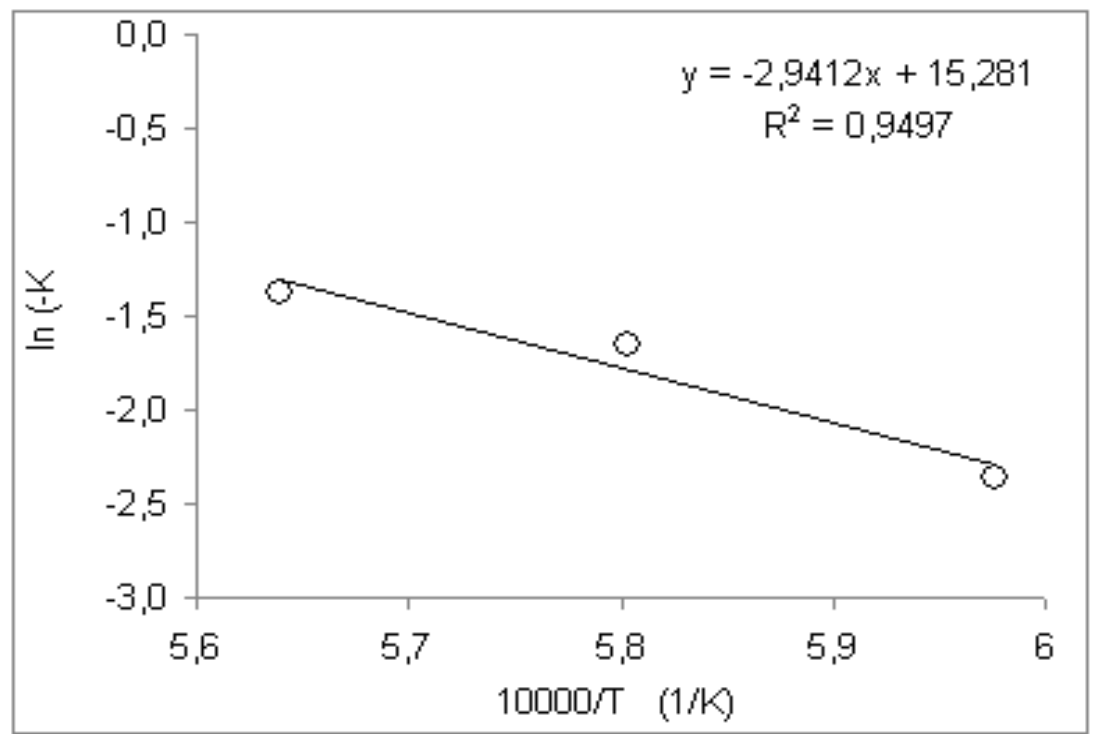

Figura 38. Curva de Arrhenius para a classe de experimentos Esteq B Si.

De posse do valor da inclinação da reta $(2,9412)$ da Figura 38 e a equação de Arrhenius, o procedimento seguinte foi o cálculo da energia de ativação aparente $\left(E_{A A}\right)$ para a classe de experimentos. Procedimento similar foi adotado para o cálculo da energia de ativação aparente $\left(E_{A A}\right)$ das demais classes de experimentos.

A Tabela 12 apresenta os valores de energia de ativação aparente.

Tabela 12. Valores de energia de ativação aparente.

\begin{tabular}{cccc}
\hline $\begin{array}{c}\text { Classe de } \\
\text { experimentos }\end{array}$ & $\begin{array}{c}\mathbf{E}_{\mathbf{A A}} \\
\mathbf{( k \mathbf { k }} \mathbf{m} / \mathbf{m o l})\end{array}$ & $\begin{array}{c}\mathbf{E}_{\mathbf{A A}} \\
\mathbf{( k J / m o l )}\end{array}$ & $\mathbf{R}^{\mathbf{2}}$ \\
\hline Esteq B Si & 58 & 245 & 0,95 \\
Hiper B Si & 120 & 504 & 1,00 \\
Hipo M Si & 31 & 131 & 0,80 \\
Esteq M Si & 9 & 39 & 0,71 \\
Hiper M Si & 37 & 154 & 0,69 \\
Hipo A Si & 31 & 128 & 0,80 \\
Esteq A Si & 18 & 75 & 0,86 \\
Hiper A Si & 42 & 177 & 0,96 \\
\hline
\end{tabular}

Observa-se na Tabela 12 que nas três classes de experimentos os valores de energia de ativação aparente são menores para as adições estequiométricas do que para as adições hiper estequiométricas. A classe de 
experimentos de adição de PAE em ferro gusa com baixo $(0,23$ a $0,36 \%)$ teor de silício (B Si) apresenta os maiores valores de energia de ativação aparente, sendo estes valores superiores até aos valores encontrados por Morsi e ElSadek $^{[73]}$ (174 a 209kJ/mol) nos experimentos sem utilização de catalizador. Os valores encontrados nas classes de experimentos de adição hipo e hiper estequiométrica em ferro gusa M Si e A Si são compatíveis com os valores encontrados por Morsi e El-Sadek ${ }^{[73]}$ (174 a 209kJ/mol) nos experimentos sem utilização de catalizador e nos experimentos com utilização de catalizador (125 a $133 \mathrm{~kJ} / \mathrm{mol}$ ) . Observa-se ainda que a classe de experimentos de adição de PAE em quantidade estequiométrica no ferro gusa com teor médio $(0,54$ a $1,14 \%$ ) de silício (Esteq M Si) apresenta o menor valor $(9 \mathrm{kcal} / \mathrm{mol}$ ou $39 \mathrm{~kJ} / \mathrm{mol})$ de energia de ativação aparente. 


\section{CONCLUSÕES}

1) A PAE no estado "como recebido" é constituída predominantemente de partículas de formato esférico e apresenta teor de ferro de 38,9\% e teor de zinco de 11,7\%; é classificada como um resíduo sólido perigoso, classe I.

2) Observou-se na PAE, através da difração de raios - $X$, a predominância da Magnetita $\left(\mathrm{Fe}_{3} \mathrm{O}_{4}\right)$, Magnesioferrita $\left(\mathrm{MgFe}_{2} \mathrm{O}_{4}\right)$ e Franklinita $\left(\mathrm{ZnFe}_{2} \mathrm{O}_{4}\right)$.

3) A PAE volatilizada é constituída predominantemente de partículas de formato lamelar. Apresenta teor de ferro de $2,41 \%$ e teor de zinco de $52,54 \%$.

4) Observou-se que o diâmetro médio de partícula da poeira resultante do processo foi de $25,9 \mu \mathrm{m}$, sendo superior ao encontrado pela PAE na forma "como recebido" $(2,281 \mu \mathrm{m})$. Além disso, observou-se que a PAE na forma "como recebido" possui $90 \%$ das partículas com granulometria abaixo de $17,1 \mu \mathrm{m}$ enquanto a poeira resultante do processo possui $90 \%$ das partículas com granulometria abaixo de $66,7 \mu \mathrm{m}$.

5) Observou-se que as condições termodinâmicas dos experimentos favorecem a redução do $\mathrm{FeO}$ da $\mathrm{PAE}$ pelo silício e pelo carbono.

6) $\mathrm{O}$ aumento da temperatura desfavorece a redução do $\mathrm{FeO}$ da escória pelo silício. Por outro lado, favorece a redução da sílica e do FeO da escória pelo carbono do ferro gusa líquido. Estes resultados também foram observados nos cálculos termodinâmicos computacionais. 
7) A reversão do silício da escória para o ferro gusa líquido ocorre de acordo com as seguintes reações: $\left(\mathrm{SiO}_{2}\right)+2 \underline{\mathrm{C}}=\underline{\mathrm{Si}}+2 \mathrm{CO}$ e $\left(\mathrm{SiO}_{2}\right)+2 \underline{\mathrm{Fe}}=2(\mathrm{FeO})+\underline{\mathrm{Si}}$.

8) Observou-se que o aumento da adição de massa de poeira (PAE) favorece a dissiliciação do ferro gusa.

9) As energias de ativação aparente encontradas estão na faixa de 75 a 177 $\mathrm{kJ} / \mathrm{mol}$ para ferro gusa com teor de silício entre 1,38 e 1,85\%, de 39 a 154 $\mathrm{kJ} / \mathrm{mol}$ para ferro gusa com teor de silício entre 0,37 e 1,14\% e de 245 a $504 \mathrm{~kJ} / \mathrm{mol}$ para ferro gusa com teores de silício entre 0,23 e $0,36 \%$. 


\section{SUGESTÕES PARA TRABALHOS FUTUROS}

7.1 Realizar estudos em escala piloto e posteriormente em escala industrial a partir dos dados apresentados nesta pesquisa para averiguar a incorporação de ferro e volatilização de zinco pela adição de PAE em ferro gusa líquido.

7.2 Avaliar o comportamento de elementos tais como $\mathrm{P}, \mathrm{K}, \mathrm{Na}, \mathrm{Cl}, \mathrm{Pb}$ e $\mathrm{S}$ contidos na PAE mediante a adição em ferro gusa líquido.

7.3 Realizar estudos de adição de PAE em ferro gusa líquido alterando-se a área do cadinho (sugestão: 65, 75 e 85 mm de diâmetro), o teor de silício do gusa (sugestão: $0,20 \%, 1 \%$ e $2 \%$ de $\mathrm{Si}$ no gusa), a massa de gusa do experimento (sugestão: $800 \mathrm{~g}, 1000 \mathrm{~g}$ e $1200 \mathrm{~g}$ ), a temperatura do experimento (sugestão: $1400,1450,1500$ e $1550^{\circ} \mathrm{C}$ ), o tempo de experimento (sugestão: 15 minutos, 30 minutos e 45 minutos) e a massa de PAE adicionada (sugestão: $5 \%$ abaixo do estequiométrico, 5\% acima do estequiométrico e estequiométrico).

7.4 Realizar um estudo econômico objetivando a implantação de uma planta em uma usina siderúrgica para adição de PAE em ferro gusa líquido. 


\section{REFERÊNCIAS}

1 SILVA, M. C.: Reciclagem de Pó de Aciaria Elétrica como Matéria-Prima na Fabricação de Materiais Cerâmicos Argilosos: Controle das Emissões Atmosféricas de Zinco. Porto Alegre: Universidade Federal do Rio Grande do Sul - UFRGS. 2006. 157 p. Tese de Doutorado.

2 ASSOCIAÇÃO BRASILEIRA DE NORMAS TÉCNICAS: NBR 10.004. Resíduos Sólidos - Classificação. Rio de Janeiro, 2004.

3 LI, C. L.; TSAI, M. S. Mechanism of spinel ferrite dust formation in electric arc furnace steelmaking. ISIJ International, v. 33, n. 2, p. 284-290, 1993

4 RUIZ, O. et al: Recycling of na electric arc furnace flue dust to obtain high grade ZnO. Journal of Hazardous Material. n. 141, p. 33-36, 2007.

5 PELINO, M. ET AL: VITRIFICATION OF ELECTRIC ARC FURNACE DUSTS. Waste Management. n. 22, p. 945-949, 2002.

6 NOLASCO SOBRINHO, P. J.: Reciclagem de Poeiras e Lamas provenientes de Fabricação de Aço Inoxidável. São Paulo: Escola Politécnica - USP. 2004. 144 p. Tese de Doutorado.

7 MANTOVANI, M. C.: Caracterização de Poeiras Geradas em Fornos Elétricos a Arco e seu Estudo quando Aglomeradas na Forma de Pelotas AutoRedutoras. São Paulo: Escola Politécnica - USP. 1998. 165 p. Tese de Doutorado.

8 Departamento Nacional de Pesquisa Mineral, DNPM: Balanço Mineral Brasileiro 2001. Disponível em www.dnpm.org.br. Acesso em abril 2012.

9 Departamento Nacional de Pesquisa Mineral, DNPM: Sumário Mineral. Disponível em www.dnpm.org.br. Acesso em abril 2012.

10 Instituto Brasileiro de Siderurgia, IBS: Produção Siderúrgica Brasileira. Disponível em www.ibs.org.br. Acesso em junho 2012.

11 NOLDIN JR., J. H.: Panorama da Siderurgia no Mundo/Brasil. Disponível em www.dema.puc-rio.br/download. Acesso em abril 2010.

12 NOLASCO SOBRINHO, P. J.; ESPINOSA, D. C. R.; TENÓRIO, J. A. S.: Caracterização da Poeira Gerada na Fabricação de Aço Inoxidável Visando a sua Reciclagem. Metalurgia e Materiais, 53 (4): 257-263, 2000

13 HAGNI, A. M.; HAGNI, R. DE; DEMARS, C.: Mineralogical Characteristics of Electric Arc Furnace Dusts. JOM, April, p. 28-30, 1991 
14 NOLASCO SOBINHO, P. J.; ESPINOSA, D. C. R.; TENÓRIO, J. A. S.: Characterization of Dusts and Sludges Generatede During Stainless Steel Production in Brazilian Industries. Iromaking and Steelmaking. V. 3, n. 1, p. 1117, 2003.

15 TAKANO, C.; CAPOCCHI, J. D. T.; NASCIMENTO, R. C.; MOURÃO, M. B.; LENZ, G.; SANTOS, D. M.: A Reciclagem de Resíduos Siderúrgicos Sólidos. Seminário Nacional sobre Reuso/Reciclagem de Resíduos Sólidos Industriais. Secretaria do Meio Ambiente do Estado de São Paulo. São Paulo, 2000.

16 DOMINGUEZ, E. A.; ULLMANN, R.; "Ecological Bricks" Made with Clays and Steel Dust pollutants. Applied Clay Science 11 (1996) 237-249.

17 BAKER, L. A.; WARD, R. G.: Reaction of na Iron-Carbon Droplet During Free Fall Through Oxygen. Jornal of the Iron and Steel Institute, v. 205, n. 7, July, p. 714-717, 1967.

18 SEBAG, M. G.; KORZENWSKI, C.; BERNARDES, A. M.; VILELA, A. C.: Evaluation of environmental compatibility of EAFD using different leaching standards. Journal of Hazardous Materials, n. 177, p. 670-675, 2009.

19 ARAÚJO, L. A. Manual de Siderurgia. Arte \& Ciência, v. 1. São Paulo. 1997.

20 MILANI, C. A. R. Sistemas de despoeiramento para fornos elétricos a arco. Uma abordagem técnico-econômica. In: Seminário sobre Fusão, Refino e Solidificação, Salvador, 1994. Anais. São Paulo, ABM, p. 91-105, 1994.

21 VON KRUGER, P. Panorama mundial de aproveitamento de resíduos siderúrgicos. Metalurgia \& Materiais - ABM, São Paulo, v. 51, n. 2, p. 116-119, 1995.

22 TURKDOGAN, E. T.; LEAKE, L. E. Preliminary studies on the evolution of fumes from iron at high temperatures. Journal of the Iron and Steel Institute, $v$. 192, n. 6, p. 162-170, 1959.

23 TURKDOGAN, E. T.; GRIEVESON, P.; DARKEN, L. S. The formation of iron oxide fume. Journal of Metal, v. 14, n. 7, p. 521-526, 1992.

24 MORRIS, J. P.; RIOTT, J. P.; IILIG, E. G. A new look at cause of fuming. Journal of Metals, v. 18, n. 7, p. 803-810, 1966.

25 ELLIS, A. F. ; GLOVER, J. Mechanism of fume formation in oxygen steelmaking. Journal of the Iron and Steel Institute. V.210, n.9, p. 593-599, 1971.

26 SEE, J. B. ; WARNER, N. A. Reactions of iron alloy drops in free fall through oxidizing gases. Journal of the Iron and Steel Institute. V. 211, n. 1, p. 44-52, 1973. 
27 RODDIS, P. G. Mechanism of decarburization of iron-carbon alloy drops falling through an oxidizing gas. Journal of the Iron and Steel Institute. V. 212, n. 1, p. 53-58, 1973.

28 TSUJINO, R.; HIRAI, M.; OHNO, T.; ISHIWATA, N.; INOSHITA, T.; Mechanism of Dust Generation in a Converter with Minimum Slag. ISIJ International, v. 29, n. 4, p. 291-299, 1989.

29 NEDAR, L.: Dust formation in a BOF Converter. Steel Reseaarch, v. 67, n. 8, p. 320-327, 1996.

30 NEDAR, L.; LINDBLOM, B.; BKORKMAN, B.: Mechanisms of Dust formation in LD Converter. Ironmaking Conference Proceedings, p. 759-766, 1996.

31 NEIGEBAUER, G. O.; GUMENNYI, V. F.; DMITRIENKO, V. I. Mechanism of dust formation during oxygen lancing of molten steel. Steel in the USSR, v. 20, n. 1, p. 272-274, 1990.

32 VARGAS, A. S.; MASUERO, A. B.; VILELA, A. C. F.: Estudo Microestrutural e Determinação do Calor de Hidratação em Pastas de Cimento Portland com Pó de Aciaria Elétrica. Ambiente Construído, v. 4, n. 2, p. 7-18, Abril/Junho, 2004.

33 BREHM, F. A.: Adição de Óxido de Zinco ( $\mathrm{ZnO}$ ) em Pastas de Cimento Portland visando Viabilizar a Reciclagem de Pões de Aciaria Elétrica (PAE) na Construção Civil. Porto Alegr, 2004. 105 p. Tese de Doutorado - Escola de Engenharia, Programa de Pós-Graduação em Engenharia de Minas, Metalúrgica e de Materiais. UFRGS.

34 MANTOVANI, M. C.: TAKANO, C.; CAVALLANTE, F. L.: Caracterização de Três tipos de Poeiras em Fornos Elétricos a Arco. 530 Congresso Anual da ABM, Belo Horizonte, 1998. p. 1329-1343.

35 PUREZA, J. C. C.: Utilização de Resíduos Industriais de Baixa Granulometria em Massas Cerâmicas de Argila Vermelha - Aspectos Tecnológicos e Ambientais. Porto Alegre, 2004. 133 p. Dissertação de Mestrado - Escola de Engenharia, Programa de Pós-Graduação em Engenharia de Minas, Metalúrgica e de Materiais. UFRGS.

36 FLORÊNCIO, R. S. V.; GOUVÊA, D.; CAMARGO, A. C.; PORTELA, J. C. S.: Fabricação de Tijolos com Matérias-Primas Argilosas do Município de Salto e Indaiatuba e com pó de aciaria elétrica. Anais do 470 Congresso Brasileiro de Cerâmica, Julho/2003.

37 NYRENDA, R.: The Processing of Steelmaking Flue-Dust: A Review. Minerals Engineering, v. 4, ns. 7-11, p. 1003-1025, 1991. 
38 MACHADO, A. T. Estudo de Incorporação e estabilização do pó de aciaria elétrica em matrizes de cerâmia vermelha. São Paulo: Escola Politécnica USP. 2005. 209 p. Tese de Doutorado.

39 TELLES, V. B.; ESPINOSA, D. C. R.; TENÓRIO, J. A. S. Recycling of the electric arc furnace dust in iron ore sintering. TMS 2012, Proceedings, p.339344, 2012.

40 ZUNKEL, A. D.; SCHIMITT, R. J.: Review of electric arc furnace dust treatment processes and environmental regulations. In: Electric Furnace Conference. Orlando, 1995. Proceedings. Warrendale, ISS, p. 147-158.

41 SUN, X.; HWANG, J.; HUANG, X.: The microwave processing of electric arc furnace dust. Journal of Materials. v. 60, n.10, 2008. p.35-39.

42 DORONIN, I. E.; SVYAZHIN, A. G.; Commercial Methods of Recycling Dust From Steelmaking. Metallurgist, v. 54, n. 9-10, p. 673-681, 2011.

43 Paul Wurth. Primus. Disponível em http://www.paulwurth.com/pt/NOSSASATIVIDADES/Tecnologias-de-Reciclagem/Primus. Acesso em 15 jul. 2011.

44 LECLERC, N.; MEUX, E.; LECUIRE, J. M.: Hydrometallurgical extraction of zinc from zinc ferrites. Hydrometallurgy, v. 70, n.3, p.175-183, 2003.

45 NAKAMURA, T.; SHIBATA, E.; TAKASU, T.: Basic Consideration on EAF Dust Treatment Using Hydrometallurgical Processes. Resources Processing, 55: 144-148 (2008).

46 XIA, D. K.; PICKLES, C. A. Microwave Caustic Leaching of Electric Arc Furnace Dust. Minerals Engeering, v. 13, n. 1, p. 79-94, 2000.

47 HAVLIK, T.; SOUZA, B. V.; BERNARDES, A. M.; SCHNEIDER, I. A. H.; MISKUFOVÁ, A. Hydrometallurgical processing of carbon steel EAF dust. Journal of Hazardous Materials, v. 135, n. 3, p. 311-318, 2006.

48 ASSOCIAÇÃO BRASILEIRA DE NORMAS TÉCNICAS: NBR 10.005. Procedimento para obtenção de extrato lixiviado de resíduos sólidos. Rio de Janeiro, 2004

49 ASSOCIAÇÃO BRASILEIRA DE NORMAS TÉCNICAS: NBR 10.006.

Procedimento para obtenção de extrato solubilizado de resíduos sólidos. Rio de Janeiro, 2004

50 ASSOCIAÇÃO BRASILEIRA DE NORMAS TÉCNICAS: NBR 10.007. Amostragem de resíduos sólidos. Rio de Janeiro, 2004 
51 MARQUES SOBRINHO, V. P. F.; OLIVEIRA, J. R.; TENÓRIO, J. A. S.; ESPINOSA, D. C. R.: Reciclagem de Poeira de Aciaria Elétrica. In: $42 \underline{0}$ Seminário de Aciaria Internacional. Salvador - Bahia. 2011.

52 FUESSLE, R. W. P. E.; TAYLOR, M. A. Long-Term solidification/stabilization and toxicity characteristcic leaching procedure for aelectric arc furnace dust. Journal of Environmental Engineering. v. 130, n. 5, p. 492-498, 2004.

53 Departamento Nacional de Pesquisa Mineral, DNPM: Anuário Mineral. Disponível em www.dnpm.org.br. Acesso em abril 2011.

54 Guia de Bolso para o Mundo do Zinco. 185 p., 2000. Associação Internacional do Zinco.

55 Consumo de Zinco está Aquecido. Revista Minérios \& Minerales. Outubro, p. 10-13, 1999.

56 OliVEIRA, G. A.; CORRÊA, M. L. R.; VERONA, M. L. R; PAIVA, L. C. Processo Eletrolítico de Galvanização da Linha de Galvanização da Usiminas. In Seminário de Zinco e suas aplicações. ABM. São Paulo. SP. 2000

57 NEWSTEEL, Recycling EAF Dust into DRI, Shingles na Rubber. Disponível em: www.newsteel.com/news/NW971201.htm. Acesso em março de 2009.

58 FARIA FILHO, S. B. Ligas de Zinco para Fundição. In Seminário de Zinco e suas aplicações. ABM. São Paulo. SP. 2000

59 MENDES, M. G. Extração, Beneficiamento e Processo Silicatado. In Seminário de Zinco e suas aplicações. ABM. São Paulo. SP. 2000.

60 CÉ, S. J. Mercado de Zinco (interno e externo). Tendências. In Seminário de Zinco e suas aplicações. ABM. São Paulo. SP. 2000

61 U.S. EPA - Office of Compliance Sector Notebook Project. Profile of the nonferrous metals industry. U.S. Environmental Protection Agency, Washington,Set. 1995. Disponível em: <http://www.epa.gov/compliance/resources/publications/ assistance/sectors/notebooks/nfmetlsnpt1.pdf>. Acesso em: 21 out. 2010.

62 FElJÓ, F. D.: Redução das perdas de zinco associadas aos processos de purificação do licor por cementação e de tratamento dos resíduos de cementação gerados da Votorantim metais. Belo Horizonte: Universidade Federal de Minas Gerais - UFMG. 2007. 178p. Dissertação de Mestrado.

63 LIMA, C. A.: Avaliação de risco ambiental como ferramenta para o descomissionamento de uma indústria de metalurgia de zinco. Rio de Janeiro: 
Escola de Química da Universidade Federal do Rio de Janeiro - UFRJ. 2009.131p. Tese de Doutorado.

64 SOUZA, A.D. Processo integrado: biolixiviação e lixiviação química na indústria do zinco. Engenharia de Minas e Metalurgia, Redemat/UFOP. 2005. 185p.Dissertação de Mestrado.

65 International Lead na Zinc Study Group, ILZSG. Disponível em www.ilzsg.org/statistics. Acesso em junho de 2011.

66 London Metal Exchange, LME. Disponível em www.Ime.co.uk. Acesso em junho de 2011.

67 MOURÃO, M. B. (COORD.): Introdução à siderurgia. Associação Brasileira de Metalurgia, Materiais e Mineração - ABM. São Paulo. 2011. p.85-94

68 SILVA, A. L. C.; MEl, P. R.: Aços e ligas especiais. Ed. Edgard Blucher. São Paulo. 2006. p. 476-484 e 491-503.

69 CAMPOS, V. F.: Tecnologia de fabricação de ferro gusa em alto-forno. UFMG. Belo Horizonte - MG. 1984. [Apostila].

70 MACHADO, M. L. P.; ARRIVABENE, L. F.; MARQUES SOBRINHO, V. P. F. Siderurgia para não siderurgistas. CST. Vitória - ES. 2003. [Apostila].

71 GEERDES, MAARTEN.; TOXOPEUS, HISKO.; VLIET, C.: Modern blast furnace ironmaking: an introduction. Delft University. ed. 2. 2009. P.117.

72 SILVA, A. L. C. Aços e Ligas Especiais. 2. Ed. Sumaré S. P. Eletrometal S. A. Metais Especiais. 1988.

73 MORSI, M. B.; EL-SADEK, M. H. Kinetic Study on the Carbothermic Reduction of Electric Ar Furnace Dust. EMC 2011, Proceedings, p. 239-248, 2011.

74 NYRENDA R.L. The processing of steelmaking flue-dust: a review. Minerals Engeering. v. 4, n. 7, p. 1003-1025, 1991.

75 ASSOCIAÇÃO BRASILEIRA DE NORMAS TÉCNICAS (ABNT). NBR 10004: resíduos sólidos - Classificação. Rio de Janeiro, 1987.

76 TELLES,V. B.; OliVEIRA, J. R.; ESPINOSA, D. C. R.; TENÓRIO, J. A. S. Pré-Tratamento da Poeira de Aciaria proveniente do Forno Elétrico a Arco Visando a Reciclagem. In: Congresso Anual da ABM, 64,2009, Belo Horizonte, Anais (CD- ROM)... MG, ABM, 2009.

77 MARTINS, F. M.; NETO, J. M. R.; CUNHA, C. J. Mineral phases of weathered and recent electric arc furnace dust. Journal of Hazardous Materials, v. 154 , n.1, p. $417-425,2008$. 
78 MENAD, N.; AYALA, J.N.; CARCEDO, F. G.; HERNÁNDEZ, A. Study of the presence of fluorine in the recycled fractions during carbothermal treatment of EAF dust. Waste Management, v. 23. n. 6, p. 483 - 491, 2003.

79 MACHADO, J. G. S.; BREHM, F. A.; MORAES, C. A. M.; SANTOS, C. A.; VILELA, A. C. F.; CUNHA, J. B. M. Chemical, physical, structural and morphological characterization of the electric arc furnace dust. Journal of Hazardous Materials, v. 136, n. 3, p. 953 - 960, 2006.

80 LAFOREST, G.; DUCHESNE, J. Characterization and leachability of electric arc furnace dust made from remelting of stainless steel. Journal of Hazardous Materials, v. 135, n. 3, p. 156-164, 2006.

81 GRILLO, F. F., Recuperação do Zn e Fe da poeira de aciaria elétrica proveniente da produção de aço carbono. 2011, 107p. Dissertação de mestrado, Instituto Federal do Espírito Santo, 2011, p. 73-85.

82 BADGER, S. R.; KNELLER, W. A. The characterization and formation of electric arc furnace (EAF) dusts. Electric Furnace Conference, 52, CHICAGO, 1997. Proceedings, p.95-97

83 OLIVEIRA, J. R. Redução do MnO pelo carbono dissolvido no banho e pelo carbono dissolvido na escória. 2008, 147p. Tese de Doutorado, Universidade de São Paulo, SP, Brasil, 2008, p. 30-60.

84 TURKDOGAN, E. T. Physical chemistry of high temperature technology, New york, Academic Press, 1980.

85 C. A. PICKLES. Reaction of electric Arc Furnace Dust with Molten Iron Containing Carbon and Silicon. Iron \& Steemaker, v. 29, n 12, p. 55-67, 2002.

86 FRUEHAN, R.J. Reactions Rates and Rate Limiting Factors in Iron Bath Smelting. Savard/Lee International Symposium on Bath Smelting, TMS, p. 233248, 1992.

87 PICKLES, C. A. Reaction of electric arc furnace dust with molten iron containing carbon. Mineral Processing and Extractive Metallurgy, v. 112, n. 2, p. 81-87, 2003.

88 PICKLES, C. A. Reaction of electric Arc Furnace Dust with Molten Iron Containing Carbon and Silicon. Iron \& Steemaker, v. 29, n 12, p. 55-67, 2002.

89 MANTOVANI, M. C.; TAKANO, C.; BUCHLER, P.M. Electric arc furnace dust-coal composite pellet: effects of pellet size, dust composition, and additives on swelling and zinc removal. Ironmaking and Steelmaking, v. 29, n. 4, p.257-265, 2002. 
90 YANG, Q.; GUSTAFSSON, B. Studies on Dust Recycling in the Electric Arc Furnace at Uddeholm Tooling AB. Scandinavian Journal of Metallurgy, v. 32, n. 3, p. 147-156, 2003. 
Anexo A - Procedimento para análise quantitativa do teor de silício do ferro gusa utilizando ensaios por via úmida 


\section{Procedimento para análise quantitativa do} teor de silício do ferro gusa utilizando ensaios por via úmida

- Pesar aproximadamente $1 \mathrm{~g}$ de amostra e passar para um béquer de $400 \mathrm{ml}$;

- Fazer a abertura com $30 \mathrm{ml}$ de $\mathrm{HCl}$ 50\% e aquecimento;

- Após completa dissolução da amsotra, adicionar $5 \mathrm{ml}$ de $\mathrm{HNO}_{3}$ concentrado, tampar com vidro de relógio;

- Deixar no calor até quase a secura, retire do calor e após ligeiro resfriamento, adicione $50 \mathrm{ml}$ de $\mathrm{HCl} 50 \%$, voltar ao aquecimento;

- Quando iniciar fervura, adicione água quente até $100 \mathrm{ml}$;

- Deixar esfriar alguns instantes e filtrar usando papel rápido mais polpa de papel, passar água quente no bequer e ter cuidado de remover todos os resíduos de silício nas paredes do bequer;

- Lavar o papel de filtro mais resíduo do funil com água quente até que o teste de fenolftaleína de negativo;

- Após a retirada da acidez, passar o papel de filtro com o resíduo para um cadinho de porcelana, secar e calcinar a $800^{\circ} \mathrm{C}$, por 30 minutos. 